\title{
EFEITO DO ENXÔFRE, APLICADO NA FORMA DE GESSO, SOBRE A PRODUÇÃO E QUALIDADE DO CAPIM COLONIÃO (D Danieum maximum JACQ.)
}

\section{CLAUDIO MALUF HADDAD \\ EMBRA PA}

Orientador: Prof. Dr. LUIZ EDUARDO GUTIERREZ

Tese apresentada à Escola Superior de Agricultura "Luiz de Queiroz", da Universidade de São Paulo, para obtenção do título de Doutor em Agronomia. Área de Concentração: Solos $\theta$ Nutriçã̃o Plantas.

PIRACICABA

Estado de São Paulo - Brasil

Outubro - 1983 
"Nós não herdamos a terra de nossos pais Nōs a tomamos emprestada de nossos filhos". Lester Brown 
Aos meus pais

Orlando e

Yvette, OFEREÇO.

Marinéia, Cecília, Claudio, Roberto, DEDICO. 
Ao Dr. Luiz EQuardo Gutierrez

Ao Dr. Godofredo Cesar Vitti

Ao Dr. Dilermando Perencin

Ao Dr. Henrique Paulo Haag

Ao Dr. Nelson José Novaes

Ao Dr. Fernando Hass

Ao Dr. Paulo Figueiredo Vieira

Ao Dr. Francisco Ferraz de Toledo

Aos Colegas do Departamento de Zootecnia

Ao Acadêmico Renato Xavier de Moraes

A Escola Superior de Agriculțura "Luiz de Queiroz"

A Empresa Brasileira de Pesquisa Agrope cuária (EMBRAPA)

SINCEROS AGRADECIMENTOS. 


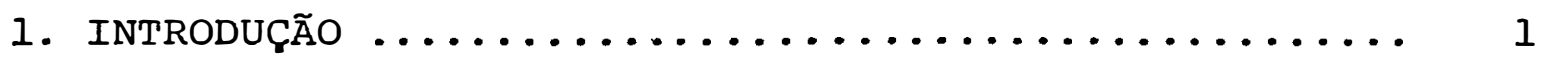

2. REVISÃo DA LITERATURA $\ldots \ldots \ldots \ldots \ldots \ldots \ldots \ldots \ldots \ldots \ldots$

2.1. o enxôfre e a nutrição animal e vegetal....... 4

2.2. Teor de enxôfre nos vegetais e sua relação com outros nutrientes e a produção global......... 6

2.3. Respostas das pastagens à adição de enxôfre e nitrogènio $\ldots \ldots \ldots \ldots \ldots \ldots \ldots \ldots \ldots \ldots \ldots \ldots \ldots \ldots \ldots$

2.4. O valor nutritivo do capim Colonião......... 26

3. MATERIAL E MEtOdos $\ldots \ldots \ldots \ldots \ldots \ldots \ldots \ldots \ldots \ldots \ldots \ldots \ldots \ldots \ldots$

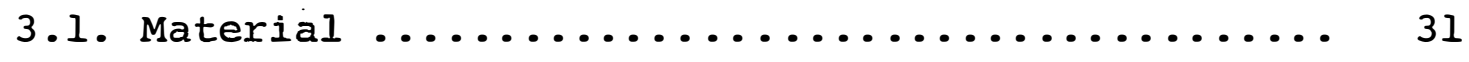

3.1.1. Solo e a espécie vegetal ........... 31

3.1.2. Material corretivo ............. 32

3.1.3. Fonte de nutrientes ............. 32

3.1.4. Recipientes ................. 33

3.2. Métodos $\ldots \ldots \ldots \ldots \ldots \ldots \ldots \ldots \ldots \ldots \ldots \ldots . . \ldots \ldots$

4. RESUltados E DISCUSSÃo $\ldots \ldots \ldots \ldots \ldots \ldots \ldots \ldots \ldots \ldots \ldots$

4.1. Efeito de doses de $\mathbf{N}$ e $\mathbf{S}$ na produção de matéria

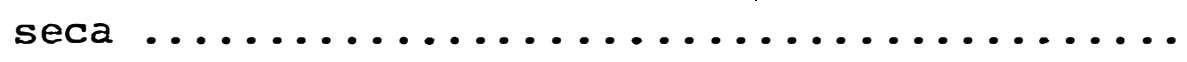


4.2. Efeito dos tratamentos sobre a concentração e quantidade absorvida de $N$, P, S e Ca......... 46

4.3. Efeito dos tratamentos sobre as relações $\mathrm{N} / \mathrm{S}$;

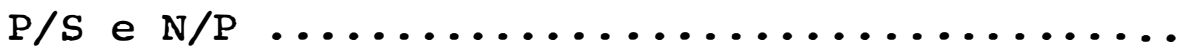

4.4. Efeito dos tratamentos sobre os teores de proteína e da digestibilidade da matéria seca...

5. CONCLUSÕES

6. LITERATURA CITADA

7. APENDICE 
LISTA DE QUADROS

Página

Quadro 1 - Relação N:S de vários produtos oriundos da ex ploração de ruminantes. Extraído de SHIRLEY e MARIANTE (1976)................... 10

Quadro 2 - Relação N:S de alguns alimentos (Extraỉdo de $s^{\circ}$ SHIRLEY E MARIANTE, 1976).............. II

Quadro 3 - Principais características químicas de amostras do solo .................... 32

Quadro 4 - Esquema dos tratamentos utilizados no experimento $\ldots \ldots \ldots \ldots \ldots \ldots \ldots \ldots \ldots \ldots \ldots$.

Quadro 5 - Doses e soluções de macro e micronutrientes utilizados .................... 36

Quadro 6 - Esquema de análise de variância na fase pre-

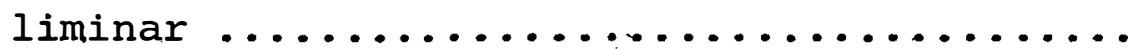

Quadro 7 - Médias gerais da produção de matéria seca, a $105^{\circ} \mathrm{C}$ da parte aérea das plantas ( $\mathrm{g} /$ vaso) em função dos níveis de $\mathrm{N}$ e $\mathrm{S}$ e resumo da análi se estạtística (Média de 4 repetições)...... 
Quadro 8 - Médias gerais da produção de matéria seca, a $105^{\circ} \mathrm{C}$ da raiz das plantas ( $\mathrm{g} /$ vaso), em função dos nĩveis de $\mathrm{N}$ e $\mathrm{S}$ e resumo da análise estatística (Média de 4 repetições)...

Quadro 9 - Médias gerais das concentrações de nitrogênio, em $\%$, na parte aérea das plantas, em função dos nỉveis de $\mathrm{N}$ e $\mathrm{S}$ e resumo da análise estatística (Média de 4 repetições)...

Quadro 10- Médias gerais das concentrações de fśoforo, em ঃ, na parte aérea das plantas, em função dos níveis de $\mathrm{N}$ e $\mathrm{S}$ e resumo da análiseestatística (Média de 4 repetições)........

Quadro 11- Médias gerais das concentrações de enxôfre, em $\%$, na parte aérea das plantas, em função dos níveis de $\mathrm{N}$ e $\mathrm{S}$ e resumo da análise estatística (Média de 4 repetições)........

Quadro 12- Médias gerais das concentrações de Cálcio, em ঃ, na parte aérea das plantas, em função dos níveis de $\mathrm{N}$ e $\mathrm{S}$ e resumo da análise estatística (Média de 4 repetições)..... 
Quadro 13- Médias gerais das quantidades de nitrogênio absorvido (mg/vaso) na parte aérea das plan tas, em função dos níveis de $\mathrm{N}$ e $\mathrm{S}$ e resumo da análise estatística (Média de 4 repeti -

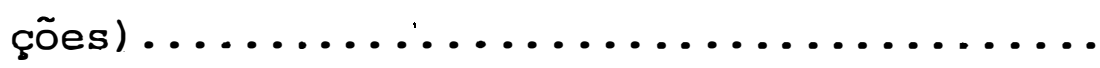

Quadro 15- Médias gerais das quantidades de enxôfre absorvido (mg/vaso) na parte aérea das plantas, em função dos níveis de $\mathrm{N}$ e $\mathrm{S}$ e resumo da análise estatística (Média de 4 repeti -

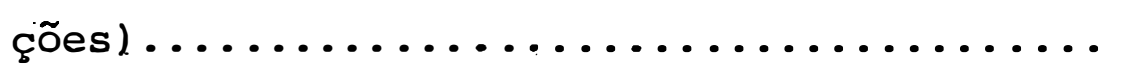

Quadro 16- Médias gerais das quantidades de cálcio absorvido (mg/vaso) na parte aérea das plantas em função dos níveis de $\mathrm{N}$ e $\mathrm{S}$ e resumo da análise estatística (Média de 4 repeti -

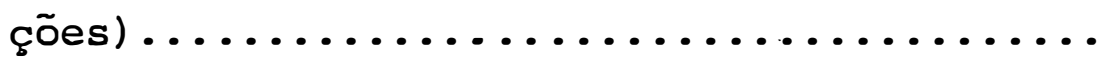

Quadro 17- Médias gerais das relações N/S da parte aérea das plantas, em função dos níveis de $\mathbf{N}$ e $S$ e resumo da análise estatística (Média

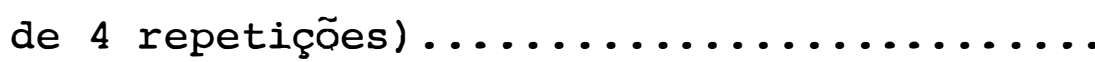

Quadro 18- Médias gerais das relações $R / S$ da parte aérea das plantas, em função dos níveis de $\mathrm{N}$ e $s$ e resumo da análise estatística (Média

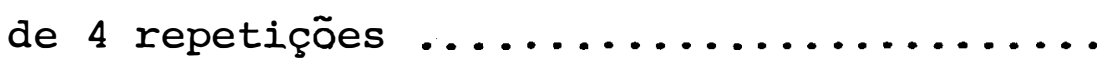


Quadro 19- Médias gerais das relações N/P da parte aérea das plantas, em função dos níveis de $\mathrm{N}$ e $\mathrm{S}$ e resumo da análise estatística (Média de 4 repetições)....................

Quadro 20- Médias gerais dos teores de proteína, em na parte aérea das plantas em função dos níveis de $\mathrm{N}$ e $\mathrm{S}$ e resumo da análise estatística (Média de 4 repetições) .............

Quadro 21- Médias gerais dos coeficientes de digestibí lidade da matéria seca, em ঃ̀, na parte aérea das plantas, em função dos níveis de $\mathrm{N}$ e $\mathrm{S}$ e resumo da análise estatística (Média de 4 repetições).................... 
LISTA DE FIGURAS

pāgina

Figura 1 - Efeito de doses de $\mathbf{S}$ na produção de matéria seca (g/vaso) da parte aérea, em cada nível

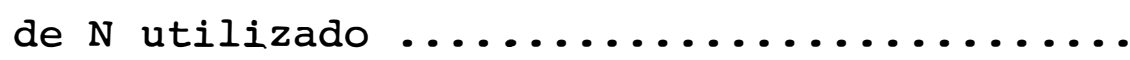

Figura 2 - Efeito de doses de $\mathbf{S}$ na produção de matéria seca (g/vaso) da raíz em cada nível de $\mathrm{N}$ uti lizado

Figura 3 - Efeito de doses de $\mathbf{S}$ na concentração de $\mathbf{S}$ das folhas, em cada nível de $\mathrm{N}$ utilizado....

Figura 4 - Efeito de doses de $S$ na concentração de: N nas folhas, em cada nível de $\mathrm{N}$ utilizado.........

Figura 5 - Efeito de doses de $S$ na concentração de $P$ das folhas, em cada nível de $\mathrm{N}$ utilizado....

Figura 6 - Efeito de doses de S, na concentração de Ca das folhas, em cada nível de $\mathrm{N}$ utilizado...

Figura 7 - Efeito de doses de $S$, na quantidade de nitrogênio extraída por vaso, em cada nível de $\mathrm{N}$ utilizado....................... 
Figura 8 - Efeito de doses de S, na quantidade de enxôfre extraída por vaso, em cada nível de $\mathrm{N}$

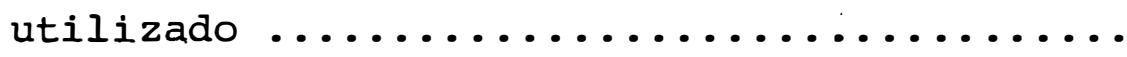

Figura 9 - Efeito de doses de $S$, na quantidade de fósfọ ro extraída por vaso, em cada nível de $\mathrm{N}$ uti lizado

Figura 10- Efeito de doses de S, na quantidade de Cálcio extraída por vaso, em cada nível de $\mathrm{N}$ utilizado

Figura 11- Efeito de doses de S na relação N/S da parte aérea em cada nível de $\mathrm{N}$ utilizado..........

Figura 12- Efeito de doses de $S$ na relação $P / S$ da parte aérea em cada nível de $\mathrm{N}$ utilizado..........

Figura 13- Efeito de doses de $S$ na relação N/P da parte aérea em cada nível de $\mathrm{N}$ utilizado...

Figura 14- Efeito de doses de $S$ no teor de proteína da matéria seca da parte aérea, em cada nível de

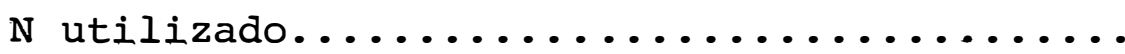

Figura 15- Efeito de doses de $\mathrm{S}$ na digestibilidade "in vitro" da matéria seca da parte aérea em cada nível de $\mathrm{N}$ utilizado ............... 76 
EFEITO DO ENXÔFRE, APLICADQ NA FORMA DE GESSO, SOBRE A PRODUÇ̃̃O E QUALIDADE DO CAPIM COLONIÃO (Panicum maximum Jacq.)

Candidato: Claudio Maluf Haddad Orientador: Prof. Dr. Luiz Eduardo Gutierrez

\section{RESUMO}

Foram conduzidos em vasos com terra em casa de vegetação, ensaios com doses crescentes de enxôfre na forma de gesso $(0,20,40,60$ e $80 \mathrm{~kg} \mathrm{~s} / \mathrm{ha})$ e nitrogênio $(0,100$ e 200 $\mathrm{kg} \mathrm{N} / \mathrm{ha}$ ) em esquema fatorial $5 \times 3$ com 4 repetições em capim Colonião (Panicum maximum, Jacq.), visando verificar o comportamento da graminea em relação à produção e qualidade (químicó bromatológico). Utilizou-se de um solo de cerrado, oriundo da região de Brotas, SP, e aos 60 dias de germinação determinouse o peso de matéria seca da parte aérea, raízes e total em ca da tratamento; os teores da parte aérea e as quantidades absorvidas de N, S, P e Ca; as relações entre os macronutrientes aniônicos $(\mathrm{N} / \mathrm{P} ; \mathrm{N} / \mathrm{S}$ e $\mathrm{P} / \mathrm{S})$ na parte aérea, o teor de proteína bruta $(N \times 6,25)$ e a digestibilidade "in vitro" da matéria seca da parte aērea. Os dados obtidos permitiram concluir que, nas condições do presente experimento: 
a - o gesso funcionou como fonte de enxtr.

cálcio para o capim Colonião;

b - houve efeito linear do $\mathrm{N}$ e quadrático do S, bem como, interação positiva quando da aplicação desses nutrientes na produção de matéria seca da gramínea. De 55 a 60 kg S/ha foi o intervalo de doses que permitiu as máximas produções de matéria seca para os níveis de $100 \mathrm{~kg} \mathrm{~N} / \mathrm{ha}$ e $200 \mathrm{~kg}$ $\mathrm{N} / \mathrm{ha}$;

c. - as quantidades absorvidas (mg/vaso) de N. S, P e Ca foram afetadas positiva e significativamente pela interação $N$ x $S$;

d - aos 60 dias pós-germinação, as relações N/S, P/S e N/P da parte aérea que permitiram máxima produção de matéria seca variaram, respectivamente, de 11,1 a 11,5; 1;3 a 1,8 e 6,0 a 8,6 ;

e - houve efeito linear da aplicação de nitrọ gênio nos teores de proteína da parte aérea, sendo que para o nível $\mathrm{N}_{2}(200 \mathrm{~kg} \mathrm{~N} / \mathrm{ha})$ o máximo teor de proteína bruta $(11,03 \%)$ foi alcançado pela aplicação de cerca de $40 \mathrm{~kg} \mathrm{~S} / \mathrm{ha}$;

f - a digestibilidade "in vitro" da matéria sẹ ca foi função da aplicação de $\mathrm{N}$ e S, alcançando valor máximo em torno de 498 pela aplicação de $50 \mathrm{~kg} \mathrm{~s} / \mathrm{ha}$ nos dois níveis de $\mathrm{N}$ utilizado (100 e $200 \mathrm{~kg} \mathrm{~N} / \mathrm{ha})$. 
EFFECT OF SULPHUR, IN GYPSUM FORM, ON THE PRODUCTION AND QUALITY OF THE "COLONIĨO" (Panicum maximum Jacg.)

Author: Claudio Maluf Haddad Adviser: Prof. Dr. Luiz Eduardo Gutierrez

SUMMARY

A 5 × 3 factorial design with four replicates envolving a trial with increasing levels of sulphur $(0,20,40$, 60 and $80 \mathrm{~kg} / \mathrm{ha})$ and nitrogen $(0,100 \mathrm{e} 200 ; \mathrm{kg} / \mathrm{ha})$ were carried out in pots in a green house with "Colonião" grass (Panicum ma$x$ imum Jacq.), to evaluate the effects of gypsum (Ca.sO $\left.4 \cdot 2 \mathrm{H}_{2} \mathrm{O}\right)$ on the nutrition of plants in an acid soil of the "cerrado" region of the state of são Paulo, Brazil.

The following parameters were determined sixty days after seeding, for each treatment:

- dry matter weight of total, aerial parts and roots

- in vitro dry matter digestibility and crude protein content of the aerial parts 
- relationship between the anionic macronutrients $(\mathrm{N} / \mathrm{P} ; \mathrm{P} / \mathrm{S}$ and $\mathrm{N} / \mathrm{S})$ in aertal parts

The following conclusions were drawn:

a - There was a linear effect of the $\mathrm{N}$ and $\mathrm{S}$ fertilization on the dry matter production. The $S$ levels, in gypsum froms that reached highest production were 55 to $60 \mathrm{~kg} / \mathrm{ha}$, corresponding to the levels of 100 and $200 \mathrm{~kg} \mathrm{~N} / \mathrm{ha}$, respectively.

b - Gypsum showed to be a good source of sulphur and calcium for. "Colonião" grass.

$\mathrm{C}-\mathrm{N} / \mathrm{S}, \mathrm{P} / \mathrm{S}$ and $\mathrm{N} / \mathrm{P}$ relations in the aerial parts, corresponding to the highest dry matter production, at the sixty days after seeding, ranged from 11,1 to 11,$5 ; 1,3$ to 1,8 and 6,0 to 8,6 , respectively.

d - Crude protein content in aerial part reached maximum value $(11,03 \%)$ by the combination $200 \mathrm{~kg} \mathrm{~N} / \mathrm{ha}$ with $40 \mathrm{~kg} \mathrm{~S} / \mathrm{ha}$.

e - When $50 \mathrm{~kg} \mathrm{~s} / \mathrm{ha}$ was utilized with the levels of $100 \mathrm{~kg} \mathrm{~N} / \mathrm{ha}$ and $200 \mathrm{~kg} \mathrm{~N} / \mathrm{ha}$, "in vitro" dry matter digestibility reached the maximum value of $49 \%$ 


\section{INTRODUÇAO}

O enxofre è um macronutriente aniônico juntạ mente com o nitrogênio e o fósforo. Nos vegetais, o enxofre se encontra formando substâncias determinantes da qualidade do produto e desempenhando funções vitais, sobretudo no metabolismo protéico, das albuminas e nas reações enzimáticas (JORDAN e ESMINGER, 1958; ALLAWAY e THOMPSON, 1966; COLEMAN, 1966). Assim, o efeito desse nutriente se faz sentir não só no aumento de produção, bem como se constitui em fator preponderante para a qualidade final do produto obtido.

A despeito de sua importância, tem sido cons tatado intenso aparecimento de deficiência de enxofre em prạ ticamente todas as regiões do globo. COLEMAN (1966) postulou que as deficiências de enxofre deveriam se agravar devido a: (1) Aumento no uso de fertilizantes e pesticidas isentos de S. (2) Aumento na produção e produtividade vegetal, trazendo 
como consequência maior extração do $\mathbf{s}$ do solo e (3) redução na emissão de $\mathrm{SO}_{2}$ industrial na atmosfera devido ao maior controle da poluição ambiental.

No Brasil, a situação tende a se agravar ain da mais com a utilização crescente de solos em áreas de cer rado, as quais são notoriamente pobres neste nutriente. Estụ dos realizados pelo Centro de Pesquisa Agropecuāria do Cerra do (CPAC), órgão da EMBRAPA admitem que após o fósforo, o enxofre é o nutriente que se apresenta mais comumente como fator limitante para o crescimento das forrageiras (LEITE e COUTO, 1982) .

Apesar de sua importância na nutrição vegetal (e animal) o enxofre tem recebido muito pouca atenção em estudos de fertilidade do solo, nutrição e adubação das plan tas, sobretudo em nosso paỉs. A negligência é explicada pelo fato de que no passado, o enxofre exigido pelo vegetal era fornecido acidentalmente através do uso de resíduos orgânicos, de adubos simples ou misturas de fertilizantes contendo esse nutriente. Entretanto, nos anos recentes, devido aos avanços na tecnologia dos fertilizantes, tem-se aumentado a produção de superfosfato triplo, fosfatos de amônio, uréia e nitrato de amônio além de misturas altamente purificadas, as quais contēm quantidades insignificantes de enxofre, insuficientes para assegurar adequada nutrição do vegetal e por ex 
tensão do animal. Nèssa fase de transiçã்o, a possibilidade do uso do gesso como adubo sulfurado é bastante promissora, uma vez que esse produto se constitui em resíduo da indústria de fertilizantes (VITTI, 1980).

MALAVOLTA (1978) calcula que a quantidade de gesso não incorporada nos adubos "concentrados" (superfosfato triplo e fosfatos de amônio) constituirá um volume de 7 milhões de toneladas anuais correspondendo a 1,2 milhões de toneladas de $\mathrm{S}$, o equivalente a 3 vezes o déficit das necessi dades brasileiras.

Dessa forma, è importante que se busquem maiores esclarecimentos sobre a utilização do gesso como fonte de enxofre, seus efeitos na produção e qualidade do produto obtido, bem como de outros parâmetros afins. 


\section{REVISAOO DE LITERATURA}

2.1. O enxofre e a nutrição animal e vegetal

O enxofre é um macronutriente aniônico, juntamente com o nitrogênio e o fósforo, se constituindo em um nutriente componente dos aminoácidos essenciais cistina, cís teỉna e metionina os quais, segundo MILLER e DONOSCO (1963) são fatores limitantes na dieta humana e animal. Além disso, o enxofre ocorre nos tecidos animais em forma de sulfato, co mo por exemplo, sulfato de condroitina, um importante componente de cartilagens, ossos e tendões da parede de vasos sanguíneos. Em ratos alimentados com dietas pobres em enxofre, foi observado um decréscimo na formação do calógeno, e também a heparina, um anticoagulante sanguíneo é um ácido sulfúrico, éster de um polissacarídeo (SHIRLEY e MARIANTE, 1976). 
O enxofre participa do metabolismo da redução do sulfato e de oxidação do sulfito, constituindo um processo integrado denominado "Ciclo do Enxofre", processo este essencialmente microbiano, e do qual as plantas e animais fazem dele alguma aplicação. Entretanto, os mamíferos não reduzem sulfato a sulfito, processo necessário à síntese de aminoácidos essenciais e das vitaminas biotina e tiamina (HOUVINEN e GUSTAFSSON, 1967).

Nas plantas, o enxofre participa como constituinte dos aminoácidos sulfurados e consequentemente da fração protéica. Assim, THOMPSON/(1957),HANSSON et alii (1941) e PIRSON, (1955), notaram que os cloroplastos contêm proteína rica em S. A deficiência de enxofre reduz fotossintese líquida através da diminuição no teor da clorofila bem como pelo decréscimo na taxa de fotossintese por unidade de clorofila (BOTTRILL et alii, 1970).

Segundo EATON (1966) a clorose associada à deficiência de $S$ relaciona-se à função do elemento como constituinte de uma proteína necessária à sintese e manutenção da clorofila. BARKER (1979) revendo a influência dos fatores nutricionais sobre a fotossintese de plantas superiores concluiu que a maioria, se não todos os nutrientes, se deficientes, afetam a estrutura do complexo fotossintético. 
ALLAWAY e THOMPSON (1966) calcularam que a população mundial demandaria em 1980, cerca de 400 toneladas de enxofre diariamente na forma de aminoácidos. Assim sendo, - fornecimento adequado de enxofre aos vegetais deverá visar a maximização da produção e o aumento do conteúdo de aminoácidos sulfurados na dieta humana e animal.

\subsection{Teor de enxofre nos vegetais e sua relação com outros nutrientes e a produção global.}

o conteúdo total de enxofre de um vegetal altera-se mais lentamente que o conteúdo de $\mathbf{S}$ em aminoácidos com a mudança no nível de $s$ disponível do solo. Considerando-se a capacidade do ruminante em obter a sintese de aminoácidos sulfurados a partir de $\mathrm{S}$ (via simbiose ruminal), a fertilização sulfurada desempenha grande efeito na qualidade nutricional das forrageiras, comparadas com 0 efeito da alimentação sobre monogāstricos (ALLAWAY e THOMPSON,1966) •

Devido à presença de enxofre nas proteínas, a ausência do elemento afeta o metabolismo intermediário do nitrogênio (RENDIG e AMPARANO, 1980). Néssas condições são observados elevados níveis de nitrogênio não protéico como amidas e nitrato (RENDIG et a $i$ i , 1976; STEWART e PORTER, 1969; FRIEDRICH e SCHRADER, 1978), evidenciando que o simples conhecimento do teor de $\mathbf{S}$ nas plantas não permite a ava 
liação nutricional das mesmas, sendo necessário saber seu rẹ lacionamento com outros nutrientes, notadamente o nitrogênio (relação N/S).

A relação $\mathrm{N} / \mathrm{S}$ da planta tem sido empregada por pesquisadores para avaliar o estado nutricional da mesma quanto ao enxofre, bem como, para avaliar a produção máxima de forragens, e para a adequada nutrição animal. Dessa forma, a relação N/S foi empregada por WALKER et alii (1956) para a avaliação do estado de $S$ em graminneas e leguminosas na Nova zelândia. Similarmente, JORDAN e ESMINGER (1958) observaram na Flórida que o desenvolvimento vegetativo do trevo estava associado com a relação $\mathrm{N} / \mathrm{S}$ da planta.

Já PUMPHREY e MOORE (1965) demonstraram que a relação N/S permanece relativamente constante nos diversos estadios de desenvolvimento da alfafa, verificando, entretan to, um decréscimo nos teores de $\mathrm{N}$ e de $\mathrm{S}$ com o desenvolvimento do ciclo da cultura, isso quando ambos nutrientes foram expressos com base na matéria seca.

A relação $\mathrm{N}: \mathrm{S}$ maior que $10: 1$ é considerada como ideal para a formação de aminoácidos microbianos conten do $S$, a nível de rủmen (NRC, 1976). Essa relação pode variar de 4:1 a 55:1 nos vegetais, sendo que na nutrição de ruminan tes, o. ideal estaria nos limites compreendidos entre 13,5: 
1 a 15:1 (BRAY e TILL, 1975).

STEWART E PORTER (1969) encontraram para tr $\underline{1}$ go e feijão, relação N:S próxima de 15:1, ao passo que para milho, o valor se estreitava para 1l:l. Entretanto, os dados desses autores referem-se a plantas em crescimento, e DJIKSHOORN e VAN WIJK (1967) demonstraram que quando a planta atinge a maturidade, a relação $\mathrm{N}: \mathrm{S}$ tende a se estabilizar em 14:1 nas gramíneas e 17:1 nas leguminosas. Ainda para as gramíneas, quando a relação encontrada for aproximadamente 16:1, pode significar que a insuficiência de S esteja limitando a sintese protéica. Para uma relação 20:1 (nas gramíneas), ocorre severa deficiência de enxofre, ao passo que a relação N:S abaixo de 15, indica acūmulo de s inorgânico|DJIKSHOORN e VAN WIJK, 1967|. Essas considerações, obviamente não seriam válidas para as Brassicas e Crucíferas, que apresentam um "consumo de luxo" de enxofre.e, consequentemente, baixa rela ção N:S. De modo geral, cereais, batata e gramíneas forragei ras apresentam menores exigências em $\mathbf{S}$ que Brassicas e leguminosas.

Vários estudos tềm demonstrado que as diversas culturas requerem uma parte de $\mathbf{S}$ para 15 partes de $\mathrm{N}$ para síntese protéica (BARKER e VOLK, 1964; PUMPHREY e MOORE, 1965; ADAMS e SHEARD, 1966).

A maior parte do $\mathrm{N}$ e do $\mathrm{S}$ nàs plantas está locali 
zadas na fração protēica, mas as plantas crescendo sob ótimas condições de fertilidade podem conter significativas quantida des de N e S inorgânicos. Quando o enxofre está deficiente, a relação $\mathrm{N}$ total:S total pode exceder a 15:1. necessário à síntẹ se protéica, e então a f̣ormação da proteína diminui ocorrendo acúmulo de nitrogênio não protéico (STEWART et alii, 1966). Esses autores notaram que quando a planta vegetava em meio deficiente de $S$, praticamente todo o $S$ se distribuiu na fração protéica. Ao se aplicar altas doses de $S$, o teor de $S$ total aumentou, mas o $S$ da fração protéica permaneceu constante, evidenciando um consumo de luxo de sulfato.

FAGERIA e SINGH (1982) alertaram para o fato de que os efeitos do enxofre e nitrogênio sobre o crescimento de uma determinada cultura, variam de forma drástica, depen dendo da espécie vegetal considerada, e do tipo de solo em que a mesma esteja vegetando. Em experimentos de adubação sul furada na Nova zelândia, McNAUGHT e CHRISTOFFELS (1961) verificaram que a relação $\mathrm{N}: \mathrm{S}$ de 17 a 18,5 para trevo branco e de 11 a 12 para gramineas, permitiram máxima produção das forrageiras. Já PUMPHREY e MOORE (1965) trabalhando no Oregon (EUA) com valores da relação N:S para prever o estado nutricional da alfafa quanto ao enxofre, verificaram que a relação N:S abaixo de 11 indicou um fornecimento adequado de enxofre, enquanto que valores de 15 a 25 mostraram progressiva deficiência em S. STEWART e WHITFIELD (1966) sugeriram uma relação $\mathrm{N}: S$ de 
17 ou menos em trigo rebrotado, como indicativa de adequado suprimento em $\mathbf{S}$.

HAAG et alii (1967) encontraram relação $\mathrm{N}: \mathrm{S}$ para o capim colonião da ordem de 16:1; 19:1 e 12:1, respectí vamente aos 28, 56 e 84 dias de desenvolvimento. Também WILSON et alii (1981) trabalhando em condições tropicais das Bahamas observaram relação $\mathrm{N}: \mathrm{S}$ de $16: 1$ para colonião não irrí gado aos 63 dias.

Os Quadros 1]e 2 sumarizam alguns valores de relação N:S encontrados em produtos de origem animal (ruminan tes) e de alguns alimentos.

Quadro 1 - Relação N:S de vārios produtos oriundos da explorạ ção de ruminantes.|Extraido de SHIRLEY e MARIANTE (1976)|.

\begin{tabular}{lll}
\hline Produto & Relação N:S & Referência \\
\hline $\begin{array}{l}\text { Carne bovina crua e } \\
\text { congelada }\end{array}$ & $15,1: 1$ & $\begin{array}{l}\text { MCCANCE e WIDDOWSON, } \\
\text { Leite integral fresco }\end{array}$ \\
Leite de cabra & $17,3: 1,9: 1$ & MOCANCE e WIDDOWSON(1940) \\
Carne ovina & $14,8: 1$ & MACANCE e WIDDOWSON(1940) \\
(quarto, assado) & $4,9: 1$ & BURNS et alii (1964) \\
Lã limpa & & \\
\hline
\end{tabular}


Quadro 2 - Relação N:S de alguns alimentos (Extraĩdo de SHIRLEY E MARIANTE, 1976).

\begin{tabular}{|c|c|c|}
\hline Alimento & Relação N:S & Referência \\
\hline Feno, alfafa & $7,4: 1$ & LOOSLI (1952) \\
\hline Silagem, milho & $16: 1$ & LOOSLI (1952) \\
\hline Trevo vermelho (feno) & $13,5: 1$ & LOOSLI (1952) \\
\hline Capim Sudão & $28,2: 1$ & LOOSLI (1952) \\
\hline Feno Timóteo & $8,5: 1$ & LOOSLI (1952) \\
\hline Cevada (grão) & $9,8: 1$ & $\begin{array}{l}\text { MITCHELL A MCLURE } \\
\text { (1937) }\end{array}$ \\
\hline Aveia (grão) & $8,5: 1$ & $\begin{array}{l}\text { MITCHELL A MCCLURE } \\
\text { (1937) }\end{array}$ \\
\hline Trevo Alsike (29 corte) & $5,1: 1$ & $\begin{array}{l}\text { CRAMPTON e HARRIS } \\
\text { (1969) }\end{array}$ \\
\hline Trevo Ladino (29 corte) & $16,7: 1$ & $\begin{array}{l}\text { CRAMPTON e HARRIS } \\
\text { (1969) }\end{array}$ \\
\hline Grãos desidratados & $10,3=1$ & $\begin{array}{l}\text { CRAMPTON e HARRIS } \\
\text { (1969) }\end{array}$ \\
\hline Milho (grão) & $11,6: 1$ & CRAMPTON e HARRIS (1969) \\
\hline Pastagens & $10,2: 1$ & $\begin{array}{l}\text { BEGG e FRENEY } \\
(1960)\end{array}$ \\
\hline
\end{tabular}


Em alguns vegetais, a taxa N:S encontrada desejāvel para seu crescimento ótimo, é- geralmente maior que a relação $\mathrm{N}: \mathrm{S}$ de $13,5: 1$ a $15: 1$ sugerida como ótima para a nutrição do ruminante. Isto sugere que embora produzam adequada massa comestivel (quantidade), certas forrageiras apresentam-se deficientes em $\mathbf{S}$ para os animais (qualidade), desde que participem como único alimento disponivel na nutrição dos mesmos.

o enxofre, talvez seja o macronutriente menos estudado, pouco se sabendo da sua concentração adequada para o crescimento normal dos diversos vegetais (MAYNARD, 1979). Entretanto, acredita-se que um mínimo de 0,1\% de enxofre na matéria seca das folhas seja suficiente para se prevenir defi ciências. Para bovinos de corte, as exigências em s situam-se em torno de $0,1 \%$ de $s$ na matéria seca da dieta (NRC, 1976).

SHEARD et alii (1978) trabalhando com pastagens consorciada ryegrass (: Lolium perene $\mathrm{L}$. ) x trevo branco na Nova Zelândia, demonstraram quea utilização do enxofre pelas plantas, através da aplicação de gesso, foi aumentada pela fertilização nitrogenada, fenômeno esse observado somente para a gramínea. A leguminosa apresentou similar utilização de S, com ou sem a presença de N. Posteriormente SHEARD(1980) trabalhando com consórcio alfafa x bromegrass (Bromus, sp.) notou que a gramínea extraiu maior quantidade de $\mathbf{s}$ do gesso que a leguminosa, embora não fosse observado incremento na 
produção de matéria seca.

RUSSELL (1961) observou que a quantidade total de enxofre extraído pelas plantas é semelhante à quantidade de fósforo, embora considera-se o enxofre como macronu triente secundário, possivelmente devido à menor ocorrência de deficiências a campo.

SHEARD (1974) notou que a habilidade da gramí snea em adquirir enxofre de uma aplicação superficial de gesso era função da fertilização nitrogenada ou dos teores de $\mathrm{N}$ do solo. Esse incremento pela interação $\mathrm{N} \times \mathrm{S}$ seria, segundo 0 autor comparável ao efeito sinergístico da interação $\mathrm{N} \times \mathrm{P}$.

Também FUJIWARA e TORRI (1961) observaram um alto teor de $\mathrm{S}$ em plantas recebendo $\mathrm{N}-\mathrm{NO}_{3}$, ao passo que WELCH et alii (1954) observaram que um aumento na concentração de nitrato na solução do solo, induzia a um decréscimo na capací. dade de absorção de enxofre e fósforo pelas raízes.

FAGERIA e SINGH (1982) citam haver tendência na qual a presença de níveis crescentes de enxofre faz com que a planta aumente 0 teor de $\mathbf{N}$ e vice-versa. Esse efeito sinergístico e recíproco de $\mathrm{N}$ e $\mathrm{S}$ é geralmente considerado co mo sendo resultado de uma absorção estimulada do anion em res posta a um aumento total na absorção do cation (REISENAUER e DICKSON, 1961; REHM E CALDWELL, 1970). 
THOMES (1959), trabalhando com milho, observou um efeito positivo e direto da fertilização sulfurada sobre o teor de nitrogênio nos grãos.

JONES E QUAGLIATO (1970) observaram que leguminosas forrageiras respondiam com maior concentração de $\mathrm{N}$ às doses crescentes de adubação com $S$, alēm de produzirem maior quantidade de matéria seca.

Entretanto, o exame da literatura também mostra resultados contraditórios quanto à afirmação de FAGERIA e SINGH e de outros (1982) anteriormente citados. Assim, MILCHUNAS et alii (1981) trabalhando com Agropyron smithii, uma gramínea nativa do Estado de Montana, observaram um efeito não significativo da fertilização sulfatada única sobre a área foliar da forrageira. Também DAS e RUNECKLES (1975) notaram a ausência de uma resposta significatị va de aplicação de sulfato sem N. BEGG e CLUGH (1973) traba lhando com Lolium perene, L. e ASHENDEN (1978) com Dactylis glo merata L. notaram que em solos com baixa disponibilidade de $\mathrm{N}$, ocorria uma redução do número de folhas mesmo quando as plantas eram expostas a altas concentrações de $\mathrm{SO}_{2}$. Trabalhando em condições de clima temperado com cevada, REISENAUER e DICKSON (196l) não observaram nenhum efeito da fertilização sulfurada sobre o teor de $\mathrm{N}$ da planta, em solos de reconhecida po- 
breza em $\mathrm{N}$ e S. Entretanto, a fertilização com $\mathrm{N}$ ou $\mathrm{S}$, promoveu aumento significativo na produção de grãos. Mais recentemente MATHENY e HUNT (1981) observaram que a fertilização sul fatada não influenciou os níveis de $\mathrm{N}$ em soja, apenas reduzin do a relação N/S devido a um aumento no teor de $S$ na porção vegetativa da planta. Talvez a explicação mais plausivel para essas discrepâncias esteja resumida na afirmação de FAGERIA e SINGH (1982) na qual os autores alertam para o fato de que os efeitos de $\mathrm{N}$ e $\mathrm{S}$ sobre o desenvolvimento de uma cultura vạ riam sobremaneira dependendo da espécie vegetal considerada e do tipo de solo em que a mesma esteja vegetando.

MCCLUNG et alii (1959) estudaram o efeito de do ses crescentes de enxofre $(0,20,40,60,80$ e $160 \mathrm{~kg} \mathrm{~s} / \mathrm{ha}$ ) em Pennisetum glaucum vegetando em solos oriundos de seis regiões do Estado de São Paulo e uma de campo cerrado de Goiás. Observaram não ocorrer resposta significativa quando o $s$ era o único elemento aplicado, e essa só acontecia em presença de níveis adequados de $\mathrm{N}$ e $\mathrm{P}$.

ATKINSON et alii (1965) estudando vários niveis de $\mathrm{S}$ e $\mathrm{P}$ em solos australianos postularam que para o estabelecimento da pastagem seria suficiente uma relação de adubação

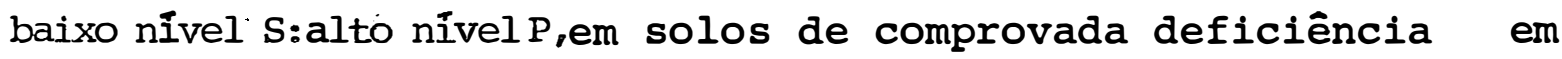
$S$ e P. Entretanto, três anos após o estabelecimento, a adubação em cobertura deveria conter uma relação alto nível s:mé- 
dio a baixo nível $P$ para se obter altas produções. Os autores justificaram essa proposição baseando-se no maior efeito residual do P em relação ao S. Entretanto, são poucos os traba lhos existentes envolvendo a relação $\mathrm{S}: \mathrm{P}$.

JONES E RUCKMAN (1972) e AULAKH E PASRICHA

(1978) notaram que altas doses de fertilizantes fosfatados in ảuziam a uma deficiência de $S$ em leguminosas. Entretanto, MnKENI e MACKENZIE (1981) não observaram tal interação e a possível explicação para esse fenômeno contraditōrio se deve a diferentes solos utilizados nos diversos experimentos.

HAAG et alii (1967) estudaram a curva de absorção dos nutrientes em colonião e outras gramineas, encon trando os valores de N, P, S e Ca na MS de 1,71\%, 0,208, 0,098 e 0,298, respectivamente, aos 56 dias de desenvolvimento. As relações N:S, N:P e P:S foram de 19, 8,55 e 2,2. Os aụ tores concluiram que o enxofre foi o macroelemento absorvido em menor quantidade em relação aos demais, considerando - se um período vegetativo de 84 dias. Posteriormente, ROMANO GALCO et alii (1974) apresentaram dados de dispersão e média dos teores de minerais em amostras de gramineas colhidas em diversas regiões do Estado de São Paulo. Considerando-se os valores médios obtidos de 14 gramíneas forrageiras, a relação P:S encontrada foi de 3,24 onde os autores só fazem menção ao estạ dio de desenvolvimento "vegetativo" em que se encontravam as for 
rageiras no momento de amostragem. Já GUIMARÃES et alii (1980) postularam que os teores de N, P, S e Ca em plantas novas de colonião giram em torno de $1,50 \% ; 0,11 \% ; 0,15 \%$ e $0,40 \%$, respectivamente, ao passo que para as plantas já maduras, os teo res seriam cerca de $1,13 \% ; 0,08 \% ; 0,11 \%$ e $1,02 \%$, respectiva mente, para $N, P, S$ e Ca na matéria seca.

\subsection{Respostas das pastagens à adição de Enxofre e Nitrogênio}

A área de cerrado em nosso Páis, nas suas diversas configurações, é estimada entre 1,5 e 2,0 milhões de $\mathrm{km}^{2}$ (RANZANI, 1971), com predominância no Planalto Central (Goiās, Minas Gerais e Mato Grosso) que abrange 77,3\% da área total estimada de cerrado e $41,7 \%$ do rebanho bovino nacional (VILELA, 1977).

$$
\text { JORDAN e ESMINGER (1958) calcularam que mais }
$$

de $70 \%$ do enxofre total dos solos poderia se encontrar na for ma orgânica, sendo esta, importante reserva de $\mathbf{S}$ para as plan tas superiores. Também McCLUNG e FREITAS (1969) notaram que em condições de queima simulada cerca de $75 \%$ do enxofre conti do na matéria seca das gramíneas perdeu-se por volatilização. Alertaram ainda, que o enxofre remanescente das cinzas era facilmente passivel de ser lixiviado. 
NELLER (1959) apontou existir alta correlação entre o sulfato extraível do solo e o teor de argila do mesmo. Assim sendo, solos com baixo teor de argila apresentam bai xos teores de $S$ extraível; permitem uma maịor infiltração de água de chuva, sendo portanto mais suscetível à lixiviação de S. Esse fenômeno foi também observado por cHAO et alii (1962), que trabalhando com solo areno-argiloso em condições đe laboratório demonstraram que $20 \mathrm{~mm}$ de água foram responsávis pela movimentação da maior porção do sulfato, para a camada abaixo dos $20 \mathrm{~cm}$ da superfície do solo. Na Nova Zelândia, GREG e GOH (1978) demonstraram haver significativa perda de enxofre em solos arenosos durante a estação chuvosa.

Considerando que os solos brasileiros de cerrado são via de regra, pobres em matéria orgânica, de constituição física predominantemente arenosa, sujeitos a uma estação chuvosa definida, e o que é mais agravante, sujeito a queimas periódicas como instrumento no manejo das pastagens, é de se prever que os teores de enxofre e nitrogênio situam se aquém das necessidades do vegetal e do animal.

Um dos poucos experimentos realizados estudan do os efeitos da adubação com $S$ sobre a qualidade nutricional da forragem é aquele de RENDIG e WEIR (1957), utilizando alfafa na alimentação de ovinos. Verificaram que a adubação sul furada promovia aumento no teor de $\mathbf{s}$ na planta, diminuia a re 
lação N/S, aumentava os coeficientes de digestibilidade da proteína e permitia maiores lotações/ārea. Esses efeitos benẹ ficos do aumento no teor de $S$ da forrageira são em parte explị cados pela alta exigência do ovino em relação ao $S$ (SHYRLEY e MARIANTE, 1976).

MCCLUNG e QUINN (1959) demonstraram em ensaios de campo que uma pastagem formada de grama Batatais (Pas palum notatum) que foi intensamente fertilizada com $\mathrm{N}$ durante 18 meses, respondeu à fertilização com S e P tanto isolada como em combinação. O tratamento combinado aumentou a produção de matēria seca atē seis vezes, tendo sido utilizado $40 \mathrm{~kg}, \mathrm{~S} /$ ha na forma de sulfato de sódio e sulfato de cálcio.

Tambēm McCLUNG et alii (1959) verificaram respostas à aplicação de enxofre, como gesso, em ensaios em vasos com milheto (Pennisetum typhoides), principalmente quando foram supridas quantidades adequadas de $N, P$ e $K$. Observaram ainda, respostas consistentes da aplicação do gesso ao hori zonte A de todos os solos estudados, enquanto a resposta à aplicação do elemento ao horizonte B foi variável com o tipo de solo, concluindo isso em termos de lixiviação do $s$ do horizonte $A$ para $O B$.

Em ensaio de pastejo de capim colonião, QUINN et alii (1961) registraram benefícios decorrentes da aplica ção de $60 \mathrm{~kg} \mathrm{~S} / \mathrm{ha}$ sob a forma de gesso sobre a capacidade de 
suporte da pastagem e produção de carne/ha em colonião adubạ do com $200 \mathrm{~kg} \mathrm{~N} / \mathrm{ha}$ e $200 \mathrm{~kg} \mathrm{P} \mathrm{O}_{5} / \mathrm{ha}$. Observaram, ainda, que em pastagens não adubadas com $\mathrm{N}$ e $\mathrm{P}$ não houve resposta ao $S$, e que não havia economicidade de fertilização com $S$ e $P$ sem o concurso de níveis adequados de N. Também Jones (1964), na California, verificou que a produção de forragem foi aumentada pela aplicação de cerca de $40 \mathrm{~kg} \mathrm{~s} / \mathrm{ha}$ na forma : de gesso, utilizando-se também cerca de $160 \mathrm{~kg} \mathrm{~N} / \mathrm{ha}$ na forma de uréia. O autor observou um aumento na taxa absorvida de $\mathrm{N}$ e $S$ nos três trevos e duas gramineas testadas.

Os dados obtidos a partir dos trabalhos de WALKER (1955), JOHANSON (1959) e FOX et alii (1964) permitem afirmar que as respostas à adubação sulfatada são notáveis na medida em que a adição de enxofre ao solo pelas águas de chuva não ultrapasse $7 \mathrm{~kg} \mathrm{~s} / \mathrm{ha} / \mathrm{ano}$, e 0 solo se apresente com baixos niveis de $\mathrm{S}$. Mais recentemente MnKENI e MACKENZIE (1981) reportaram uma adição de $10 \mathrm{~kg} \mathrm{~s} / \mathrm{ha} / \mathrm{ano}$ em solos de região não industrializada no Canadā, não observando respostas significativas à fertilização com s.

SANCHES (1976) afirma que, em geral, 10 a 40 $\mathrm{kg} \mathrm{s} / \mathrm{ha} / \mathrm{ano}$ são suficientes para se prevenir quaisquer sinto mas de deficiência de $S$ nas plantas. Essa pequena necessidade em $S$, principalmente para gramíneas forrageiras, aliado ao fato da adição do elemento via água de chuva, talvez ex- 
plique a ausência de resposta à adubação sulfurada em algumas propriedades agro-pastorís no Estado de são Paulo.

O trabalho de WENDT (1970) conduzido em Ugan da ressalta também a importância do enxofre na adubação de gramineas e leguminosas tropicais. Verificou-se que a resposta dos capins Jaraguã e Colonião ao nitrogênio $(44 \mathrm{~kg}$ $\mathrm{N} / \mathrm{ha} /$ corte) e do estilosantes ao fósforo (superfosfato duplo) foi visivelmente incrementada em presença de enxofre na forma de gesso. Ademais verificou-se que enquanto a combinação fósforo + enxofre aumentava o rendimento forrageiro do colonião e deprimia seu teor protéico, no caso do estilo santes resultava em aumento no rendimento forrageiro como do teor protéico ( $k g$ proteina/ha).

MCCLUNG e FREITAS (19 9) estudando 3 latosso los golanos e uma terra roxa paulista em casa de vegetação e trabalhando com azevém e alfafa encontraram respostas à adubação com $\mathbf{S}$ nos quatro solos, sempre que houve aplicação de P. Também McClung et aliii(1959) estudaram o efeito de doses crescentes de $S(0,20,40,80$ e $160 \mathrm{~kg} / \mathrm{ha})$ em Pennisetum graucum em solos oriundos de 6 regiões do Estado de são Paulo e uma de campo cerrado de Goiās. As respostas máxi mas foram obtidas com a aplicação de $20 \mathrm{~kg} \mathrm{~s} / \mathrm{ha}$ sendo que as maiores produções foram observadas em solo de cerrado goiano. Os autores também notaram que não havia resposta significativa quando o enxofre era o único elemento aplica- 
do e essa só ocorria em presença de nỉveis adequados de $\mathrm{N}$ e P. Trabalhando com leguminosas tropicais e uma de clima temperado, JONES e QUAGLIATO (1970) estudaram as respostas em rendimento forrageiro perante doses crescentes de enxofre. Observou-se um aumento na produção de matéria seca na proporção do aumento do suprimento de S para Centrosema, So ja perene e Alfafa. Dos 3 cortes realizados, o efeito mais pronunciado foi no 39 corte, com exceção ao stylosanthes gracizis cujo desenvolvimento pareceu ter sido limitado por outro fator. Os autores também assinalaram que a concentração de nitrogênio tende a aumentar com a aplicação de doses crescentes de S. Tambēm a omissão de S na adubação determinou significativa redução nas produções de matéria seca do estilosantes, soja perene e alfafa (Martim e Walker, citados em JONES et a Zii, 1970; MARTEL e ZIZKA, 1977).

Tambēm FARINA et aZii(1972), na Ãfrica do Sul, fornecendo superfosfato simples e um fosfato de rocha em pastagem consorciada Paspalum dilatatum x Trifolium repens cv. Ladino verificaram que o aumento na matéria seca da pastagem foi devido ao enxofre e não ao fósforo do adubo, estimando ainda em $30 \mathrm{~kg} \mathrm{~S} / \mathrm{ha}$ como a necessidade das pastagens quanto ao enxofre.

Usando solo de um pasto de colonião considerado esgotado por não ter recebido qualquer adubação ou ca- 
lagem, WERNER et alii (1967) através de ensaios com colonião em vasos verificaram que o fósforo foi o elemento que mais limitou o crescimento, seguido do nitrogênio e enxofre.

Em clássico trabalho de pesquisa, ROMANO GAL Lo et alii (1974) analisaram 41 amostras de colonião oriundas de pastagens localizadas em diversos pontos do Estado de São Paulo, encontrando valores de dispersão para o enxofre, variando de $0,012 \%$ a $0,167 \%$ de $S$ na matéria seca, e média das 41 amostras de $0,065 \% \mathrm{~s}$. Considerando as amostras de 14 diferentes gramíneas forrageiras em território paulista, os autores notaram que 63\% desse universo de análises apresentavam teores abaixo de $0,1 \% \mathrm{~S}$, considerado - mínimo necessário para haver adequada nutrição de $S$ para bovinos de corte (NRC, 1976). Observaram também que $\mathrm{N}, \mathrm{P}$ e S foram elementos limitantes para a exploração da pecuária a pasto, uma vez que a maioria das gramíneas amostradas pos suiam baixas concentrações desses nutrientes.

Mais recentemente CASAGRANDE e CORREA DE SOU ZA (1982) estudaram as respostas dos capins gordura, Jaraguá, braquiāria (B. decumbens) e setaria (Setaria anceps cv Kazungula) a 5 niveis de $S(0,15,30,45$ e $60 \mathrm{~kg} \mathrm{~s} / \mathrm{ha}$ ) em três solos de cerrado do Mato Grosso do Sul. A maior frequência da resposta ao enxofre deu-se com a aplicação de até $30 \mathrm{~kg} \mathrm{~S} / \mathrm{ha}$, sendo que a braquiāria e o gordura foram as 
forrageiras que melhor responderam em rendimento/ha.

A adubação nitrogenada é talvez o fator que mais interfere na produção e qualidade da planta forrageira. Trabalhos realizados em Porto Rico demonstraram uma resposta linear da produção em matéria seca do capim Elefante (Pennisetum purpureum Schum) até o nivel de $800 \mathrm{~kg}$ N/ha (VICENTE CHANDLER et alii, 1959). Também CARO-COSTA et alii (1960) trabalhando com capins Napier, colonião, angola e gordura observaram aumento na produção de MS quando da fertí lização nitrogenada. Ainda CLATWORTHY (1967) com capim de Rhodes, GOMIDE et alii (1969) e OLSEN (1974) com vārias forrageiras observaram resposta em rendimento à aplicação de $\mathrm{N}$. Simultaneamente ao efeito positivo sobre a produção, nota-se também que a fertilização nitrogenada eleva o teor protéico da forragem como ilustram os trabalhos de AWAN (1965), ADAMS (1967) e OLSEN (1974). O nitrogênio também concorre para o maior perfilhamento das gramineas (LANGER, 1963;HALSE et alii,! 1969), eleva significativamente a ārea foliar (LANGER e LIEW, 1973; SPIERTZ e VANDER HAAR, 1978) e aumenta a velocidade de expansão das folhas novas (SUGIMOTO e NIKKI, 1977).

MOTT et alii (1965) comparando o desempenho de novilhos Nelore em pastos de Colonião com $P$ e $S$ no plantio e niveis de zero e $100 \mathrm{~kg} \mathrm{~N} / \mathrm{ha}$ em cobertura, encontraram para a pastagem que recebeu fertilização nitrogenada 
uma maior taxa de lotação e maior produção de carne/ha. Os autores correlacionaram esse desempenho com a ação do $\mathbf{N}$ aumentando o teor de proteina bruta das pastagens no inverno, e também pela maior produção forrageira nesse periodo. Também QUINN et alii (1965) comparando o desempenho de novilhos Nelore em 6 gramineas forrageiras (dentre as quais - colonião) adubadas com $100 \mathrm{~kg} \mathrm{~N} / \mathrm{ha}$ e não adubadas observa ram que a produção de carne/ha foi maior para todos os pastos que receberam $\mathrm{N}$ em relação ao controle. Entretanto, os autores não notaram nenhum efeito significativo da adubação nitrogenada sobre a capacidade de suporte das pastagens. A explicação para esse fenômeno se deveu ao fato da cobertura nitrogenada ser realizada no período de "inverno", pois os fatores fotoperíodo e temperatura agem como limitantes do crescimento. Jã PEDREIRA et alii (1965) estudando a introdução de gramineas e leguminosas no sul do Estado de são Paulo, observaram que o capim Sempre-Verde (Panicum maximum cv. gongyloides) respondeu a uma adubação completa da ordem de $310 \%$ a mais na produção de matéria seca e $270 \%$ a mais em proteina/ha em relação a parcelas não adubadas. Em experi mento envolvendo diferentes gramineas forrageiras e doses de $N$, CIAT (1979) informou que mesmo a nível zero de $N$, O capim Colonião produziu cerca de 13 ton MS/ha. Entretanto, em outro experimento onde testou-se o nivel zero de P, a produção do colonião foi irrisória (CIAT, 1978). 


\subsection{O valor nutritivo do capim Colonião.}

MINSON e MCLEOD (1970) tomando a digestibilidade da matéria seca como parâmetro para definir a qualidade da forragem, notaram que a amplitude de variação na qualidade das plantas forrageiras é considerável, e que os valores de coeficiente de digestibilidade da matéria seca das plantas tropicais e temperadas se inseriam dentro de um amplo intervalo variando de $35 \%$ a $75 \%$

JOHNSON et alii (1967) trabalhando com bovinos na determinação da digestibilidade aparente da matéria seca do colonião, observaram uma pequena variação de valores em relação ao estadio vegetativo da forrageira. Assim sendo, os coeficientes de digestibilidade encontrados para a matéria seca foram de 53,5\% na forragem fresca, 55,5\% na préfloração e $54 \%$ na floração. Entretanto, ASARE (1974) em Ghana, trabalhando com diversas gramíneas e leguminosas encontrou para o Colonião uma variação nos coeficientes de digestibilidade da Matéria Seca "in vitro" de 37,48 a 51,6\%. Na Venezuela, trabalhando com bovinos como animal-teste, BUTTERWORTH (1967) encontrou o valor de 47,9\% para o coeficien te de digestibilidade aparente da matéria seca do colonião cortado aos 63 dias de desenvolvimento. 
Nigéria, encontraram o valor de $59 \%$ de digestibilidade ' da matéria seca para o Colonião cortado aos 56 dias.

Em Pirassununga - SP., VELLOSO et alii (1978) obtiveram os valores de $35,8 \%$ e $4,8 \%$, respectivamente, para digestibilidade da MS do colonião com bovinos e teor de prọ teina bruta da forrageira cortada aos 60 dias de idade. Já GOMIDE et alii (1979) trabalhando com 4 estações de cres cimento, encontraram para colonião aos 63 dias de desenvolvimento e adubado, valores médios de $51,8 \%$ para digestibilí dade "in vitro" da matéria seca. Também zAGo e GOMIDE (1982) trabalhando com capim colonião adubado com $170 \mathrm{~kg} \mathrm{~N} / \mathrm{ha}$ e aos 63 dias de desenvolvimento, valores médios de 3 épocas de corte da ordem de $53,5 \%$ de digestibilidade "in vitro" da matéria seca, 6,3\% de proteína bruta, 0,30\% Ca e 0,16\% P.

FRENCH e CHAPARRO (1960) estudando a composi ção química de diversos pastos na Venezuela durante a estação seca, encontraram para o capim Colonião, teores de proteína bruta variando de $4,3 \%$ a $10,5 \%$ na matéria seca.0 teor de Ca variou de $0,13 \%$ a $0,47 \%$, sendo que apenas duas amostras em 30, apresentaram com teores abaixo de 0,20\%, minimo exí gido para adequada nutrição de ruminantes. Já o teor de fósforo apresentou-se deficiente (menos que 0,20\% P na matéria seca) na quase totalidade das amostras.

HAAG et alii (1967) estudando a curva de ab- 
sorção de nutrientes de diversas gramíneas forrageiras, encontraram valores de $0,298 \mathrm{Ca}, 0,208 \mathrm{P}$ e $0,098 \mathrm{~S}$ para colonião cortado aos 56 dias de desenvolvimento.

Estudando o efeito de diversos níveis de enxofre sobre a qualidade das forrageiras, BARTON et a $i$ i (1971) concluíram que aumentando-se a porcentagem de enxo fre total na matēria seca da forrageira, via adubação, promovia-se um aumento linear no coeficiente de digestibilidade "in vitro" da celulose. Também KENEDY (1974) relatou que a adição de sulfato de cálcio a uma dieta de bovinos compos ta de Heteropogum contortus e Stylosanthes humilis originou um pequeno aumento na digestibilidade da matéria seca.

HAGGAR e AHMED (1970) postularam que a forrageira para ser considerada ideal na nutrição de ruminantes deveria apresentar uma digestibilidade da matéria seca da ordem de $65 \%$ e um nível mínimo de $7 \%$ proteína bruta. Tam bém JARDIM et alii (1962) citam que $8 \%$ de proteína bruta na matéria seca é o mínimo valor para a planta não ser considẹ rada deficiente à nutrição do ruminante. Entretanto, essa combinação de valores não é fácil de se obter no manejo da forrageira. MINSON (1971) utilizando ovinos em teste de di gestibilidade aparente da MS do feno de colonião com 63 dias de estadio vegetativo obteve o valor de 53,4\%. Também MENESES et alii (1973) utilizando ovinos como animal-teste, 
obtiveram para feno de colonião cortado aos 63 dias, o valor de 53,5\% de digestibilidade da matéria seca. Já MURIETA (1978) trabalhando com capim colonião (forragem verde) obteve 55,78\% de digestibilidade "in vitro" da matéria seca, aos 53 dias de desenvolvimento. O mesmo autor cita o valor de $8,28 \%$ de proteína bruta na matēria seca, para feno de colonião adubado com $60 \mathrm{~kg} \mathrm{~N} / \mathrm{ha}, 50 \mathrm{~kg} \mathrm{P} \mathrm{P}_{5} / \mathrm{ha}$ e $60 \mathrm{~kg} / \mathrm{O}$ ha cortado aos 53 dias.

TESSEMA (1972) utilizando $100 \mathrm{~kg} / \mathrm{ha}$ da förmu la 14-4-10 obteve para colonião, valores de 9,5\% PB, 4,4\% $\mathrm{PB}$ e $4,9 \% \mathrm{~PB}$, respectivamente, para cortes realizados aos 28, 49 e 56 dias de desenvolvimento. Em Porto Rico, KAYONGOMALE et alii (1976) utilizando $350 \mathrm{~kg} / \mathrm{ha}$ de nitrato de amônio encontraram para o colonião cortado aos 30 dias valores de 60,8\% de digestibilidade "in vitro" da matéria seca e 14,208 proteina bruta.

Vários são os fatores climáticos capazes de afetar o valor nutritivo das forrageiras. De interesse espe cífico para o presente trabalho, cita-se a temperatura. coo PER e TAINTON (1968) afirmaram que gramíneas tropicais cres cem mais vagarosamente quando a temperatura oscila entre 10 e $15^{\circ} \mathrm{C}$, apresentando crescimento máximo quando a temperatura alcança uma faixa de 30 a $35^{\circ} \mathrm{C}$. DEINUM et a $i i$ observaram em condições controladas que temperaturas mais 
altas favoreciam a conversão dos produtos fotossintēticos em matéria estrutural, alēm de efeito direto sobre a lignificação das plantas forrageiras. Os efeitos prejudiciais da temperatura sobre a qualidade da forrageira relacionamse com as taxas de crescimento das plantas e a formação de hastes em detrimento de folhas (WILSON e MINSON, 1980). Ainda MASUDA (1977) postulou que temperaturas mais altas aceleram a taxa de aparecimento das folhas, estimulam a formação de hastes, reduzem a formação de novos perfilhos, fatores estes que associados concorrem para uma maturidade precoce da planta e, consequentemente, reduzem a digestibi lidade da matéria seca. 
3. MATERIAL E METODOS

\subsection{Material}

o experimento foi conduzido em casa de vegetação do Departamento de Agricultura e Horticultura, na Escola Superior de Agricultura "Luiz de Queiroz", em Piracicaba - SP, no período de setembro de 1981 a maio de 1982.

\subsubsection{Solo e Espécie Vegetal}

Utilizou-se de um solo ácido de cerrado de ocorrência no município de Brotas - SP. As análises químicas do mesmo, realizadas no Departamento de Solos, Geologia e Fertilizantes da E.S.A. "Luiz de Queiroz", são apresentadas no Quadro 3. 
Quadro 3 - Principais características químicas de amostras do solo*

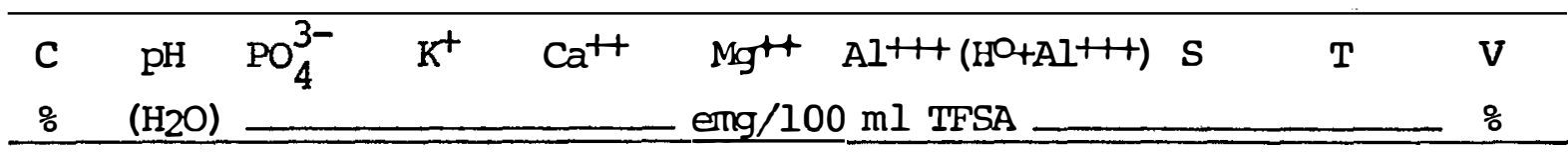

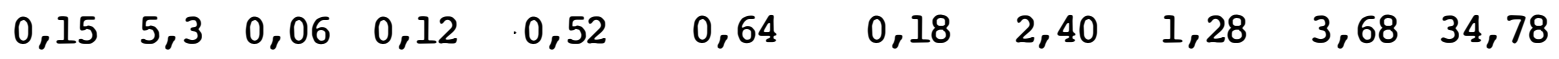

* Obtidas de acordo com a metodologia descrita em CATANI e JACINTO (1974).

o vegetal escolhido como planta teste foi o capim Colonião (Panicum maximum Jacq.).

\subsubsection{Material Corretivo}

Foi utilizado o calcārio dolomítico calcinado (Aplical Agrícola, AC-30), cuja análise efetivada no Departamento de Química da E.S.A. "Luiz de Queiroz", revelou as seguintes características físico-químicas:

\begin{tabular}{ccccc}
\hline$\%$ material retido em peneira & & & \\
\hline $2 \mathrm{~mm}$ & $0,3 \mathrm{~mm}$ & & & \\
\hline 0,4 & 37,2 & 36,4 & 24,6 & 97,47 \\
\hline
\end{tabular}

3.1.3. Fonte de nutrientes

Os macronutrientes $\mathrm{N}, \mathrm{P}, \mathrm{K}$ e $\mathrm{S}$ foram fornecidos respectivamente na forma de uréia (43\%N), superfosfa- 
to triplo $\left(42 \% \mathrm{P}_{2} \mathrm{O}_{5}\right)$, cloreto de potássio $\left(60 \% \mathrm{~K}_{2} \mathrm{O}\right)$ e gesso (15\% S). Os micronutrientes $\mathrm{B}, \mathrm{Cu}, \mathrm{Fe}, \mathrm{Mn}, \mathrm{Mo}$ e $\mathrm{Zn}$ foram fornecidos como drogas p.a. respectivamente, nas formas de $\mathrm{H}_{3} \mathrm{BO}_{3}$, $\mathrm{CuCl}_{2}, \mathrm{Fe}-\mathrm{EDTA}, \mathrm{MnCl}_{2} \cdot 4 \mathrm{H}_{2} \mathrm{O}, \mathrm{Na}_{2} \mathrm{MOO}_{4}$ e $\mathrm{ZnO}$.

\subsubsection{Recipientes}

Utilizaram-se de vasos de barro com 6,0 kg de capacidade para TFSA, pintados internamente com "neutrol", dotados de coletor também de barro e apresentando no fundo dos vasos um furo central de $1 \mathrm{~cm}$ de diâmetro de forma a facị litar à aeração e possível escoamento de água.

\subsection{Métodos.}

a) Coleta e preparo das amostras de terra Foram retiradas amostras de terra do solo já citado na profundidade de 0 a $25 \mathrm{~cm}$, as quais apoós destộ roadas foram postas a secar ao ar, passadas em peneira com malha de $2 \mathrm{~mm}$ e uniformizadas por misturas sucessivas de por ções.

b) Incubação das amostras com calcário

De posse da análise química do solo foi determinada a necessidade de calagem visando elevar o teor de $\mathrm{Ca}^{++}+\mathrm{Mg}^{++}$do nível de $2,0 \mathrm{emg} / 100 \mathrm{ml}$ TFSA. A quantidade 
de calcário determinada foi equivalente a $1,68 \mathrm{t} / \mathrm{ha}$.

Assim, foram tomados aproximadamente $500 \mathrm{~kg}$ de TFSA esparramados uniformemente sobre uma lona plástica, aplicando o calcário e muito bem homogeneizado. Em seguida, adicionaram-se 12 litros de água destilada para cada $100 \mathrm{~kg}$ de TFSA deixando-se o solo assim incubando por um período apro ximado de 20 dias. Durante esse período procedeu-se a um revolvimento constante dos solos, bem como uma reposição de sua umidade a cada 3 dias.

c) Tratamentos

Os tratamentos, cinco níveis de $S$, três nîveis de $\mathrm{N}$ e quatro repetições foram montados num delineamento inteiramente casualizado com esquema fatorial (5x3), conforme dados do Quadro 4.

d) Instalação do ensáio

d.1) Adubação básica dos vasos

Após a pesagem de $6 \mathrm{~kg}$ de TFSA, procedeu- se a uma adubação básica dos mesmos, sendo que as soluções de micronutrientes foram baseadas em HOAGLAND e ARNON (1950), conforme dados do Quadro 5.

d.2) Enxofre (s)

O enxofre foi fornecido como gesso ( $\left.\mathrm{CaSO}_{4} 2 \mathrm{H}_{2} \mathrm{O}\right)$ 
Quadro 4 - Esquema dos tratamentos utilizados no experimento

\begin{tabular}{|c|c|c|c|c|c|c|c|}
\hline \multicolumn{2}{|c|}{ Níveis } & \multirow{2}{*}{$\begin{array}{l}\text { de } \\
\mathrm{N}\end{array}$} & \multirow{2}{*}{$\begin{array}{c}\text { Vasos } \\
\text { no }\end{array}$} & \multirow{2}{*}{$\begin{array}{c}\text { Gesso } \\
\text { mg/vaso }\end{array}$} & \multirow{2}{*}{$\begin{array}{c}\mathrm{s} \\
\mathrm{kg} / \mathrm{ha}\end{array}$} & \multirow{2}{*}{$\begin{array}{c}\text { Urēia } \\
\text { ml/vaso }\end{array}$} & \multirow{2}{*}{$\begin{array}{c}\mathrm{N} \\
\mathrm{kg} / \mathrm{ha}\end{array}$} \\
\hline$S$ & e & & & & & & \\
\hline 0 & - & 0 & $1-4$ & 0 & 0 & 0 & 0 \\
\hline 0 & - & 1 & $5-8$ & 0 & 0 & 60 & 100 \\
\hline 0 & - & 2 & $9-12$ & 0 & 0 & 120 & 200 \\
\hline 1 & - & 0 & $12-16$ & 320 & 20 & 0 & 0 \\
\hline 1 & - & 1 & $17-20$ & 320 & 20 & 60 & 100 \\
\hline 1 & - & 2 & $21-24$ & 320 & 20 & 120 & 200 \\
\hline 2 & - & 0 & $25-28$ & 640 & 40 & 0 & 0 \\
\hline 2 & - & 1 & $29-32$ & 640 & 40 & 60 & 100 \\
\hline 2 & - & 2 & $33-36$ & 640 & 40 & 120 & 200 \\
\hline 3 & - & 0 & $37-40$ & 960 & 60 & 0 & 0 \\
\hline 3 & - & 1 & $4 \cdot 1-44$ & 960 & 60 & 60 & 100 \\
\hline 3 & - & 2 & $45-48$ & 960 & 60 & 120 & 200 \\
\hline 4 & - & 0 & $49-52$ & 1280 & 80 & 0 & 0 \\
\hline 4 & - & 1 & $53-56$ & 1280 & 80 & 60 & 100 \\
\hline 4 & - & 2 & $57-60$ & 1280 & 80 & 120 & 200 \\
\hline
\end{tabular}

nas doses já enumeradas na Tabela 3, misturado com o superfos fato triplo e distribuídos de modo uniforme e muito homogenei zados com a terra antes da semeadura do capim.

$\mathrm{d}_{3}$ ) Nitrogênio (N)

o nitrogênio foi fornecido como uma solução 
de uréia $(9,3 \mathrm{~g} / \mathrm{l})$, sendo aplicado no plantio $18 \mathrm{ml}$ dessa solução/vaso (30 kg/ha de $\mathrm{N})$ nos vasos correspondentes aos nĩveis 1 e 2 de $N$, enquanto que 20 dias após a germinação do capim foram aplicados $42 \mathrm{ml}(70 \mathrm{~kg} / \mathrm{ha}$ de $\mathrm{N})$ e $102 \mathrm{ml} \mathrm{da}$ solução por vaso $(170 \mathrm{~kg} / \mathrm{ha}$ de $\mathrm{N})$ respectivamente nos tratamentos correspondentes aos níveis 1 e 2 de $\mathrm{N}$.

Quadro 5 - Doses e soluções de macro e micronutrientes utilizados

\begin{tabular}{|c|c|c|c|}
\hline Nutriente & & Soluções & Epoca de aplicação \\
\hline & $\mathrm{kg} / \mathrm{ha}$ & & \\
\hline $\mathrm{P}_{2} \mathrm{O}_{5}$ & 150 & 857 mg super triplo/vaso & plantio \\
\hline \multirow[t]{2}{*}{$\mathrm{K}_{2} \mathrm{O}$} & 60 & $4,09 \mathrm{KCl} / \mathrm{l}$ & $\begin{array}{l}20 \mathrm{~kg} / \mathrm{ha} \mathrm{K}_{2} \mathrm{O} \cdot \mathrm{plantio} \\
40 \mathrm{~kg} / \mathrm{ha} \mathrm{K}_{2} \mathrm{O} \cdot \mathrm{p} \text { Jantio }\end{array}$ \\
\hline & ppon & . & \\
\hline B & 0,5 & $286 \mathrm{mg} \mathrm{H}_{3} \mathrm{BO}_{3} / \mathrm{l}$ & \\
\hline $\mathrm{Cu}$ & 1,5 & $402 \mathrm{mg} \mathrm{CuCl} \mathrm{Cll}_{2}$ & $\begin{array}{l}\text { Solução única } \\
\text { plantio: } 50 \mathrm{ml} / \text { vaso }\end{array}$ \\
\hline $\operatorname{Mn}$ & 3,0 & $1,8 \mathrm{~g} \mathrm{MnCl}_{2} 4 \mathrm{H}_{2} \mathrm{O} / 1$ & \\
\hline Mo & 0,1 & $23 \mathrm{mg} \mathrm{Na} 2 \mathrm{MOO}_{4} 2 \mathrm{H}_{2} \mathrm{O} / \mathrm{l}$ & \\
\hline $\mathrm{Zn}$ & 5,0 & $645 \mathrm{mg} \mathrm{Zno} / \mathrm{l}$ & $\begin{array}{l}\text { Suspensão plantio } \\
50 \mathrm{ml} / \text { vaso }\end{array}$ \\
\hline $\mathrm{Fe}$ & 5,0 & $\mathrm{Fe}$ - EDTA & $5 \mathrm{ml} /$ vaso no plantio \\
\hline
\end{tabular}

d.4) Semeadura e desbaste

Após a adição de água destilada nos vasos de modo a elevar a umidade do solo a cerca de $2 / 3$ da capacidade de campo, os mesmos foram pesados individualmente e anotados 
os seus pesos. Em seguida foram distribuídos regularmente sementes por vaso a profundidade de cerca de $1,0 \mathrm{~cm}$.

Dez dias após a germinação foi feito o desbaste em todos os vasos, deixando-se 5 plântulas por vaso.

e) Regas

Duas ou três vezes por semana, foram pesados alguns vasos ao acaso, e restituído o peso de água evaporada, tirando uma média que se aplicou a todos os vasos (usou-se sem pre água destilada).

$\bar{A}$ medida que as plantas foram crescendo,

quantidade de água adicionada aumentou. Estimou-se a quantidade requerida pela observação do grau de umidade do solo e a aparência das plantas. O excesso de água que percolou para o coletor foi devolvido à superfície do vaso.

\section{f) Colheita}

o corte da gramínea foi efetivado aos

dias após a germinação, cortando-se as plantas ao nível do colo, deixando-se secar em estufa $\left(7,0^{\circ} \mathrm{C}\right)$ até peso constante. Após uma semana da coleta da parte aérea procedeu-se a coleta das raỉzes, as quais após serem lavadas diversas vezes com água destilada foram postas a secar a $70^{\circ} \mathrm{C}$ e pesadas.

Do material (parte aérea e raízes) colhido 
e seco a $70^{\circ} \mathrm{C}$, foram tomadas amostras para determinação de matéria seca a $105^{\circ} \mathrm{C}$.

g) Análises minerais

Para a determinação de elementos minerais utilizou-se dos seguintes métodos analíticos; nitrogênio-semi micro Kjeldahl, fósforo-colorimetria do molibdato de amônio, cálcio-absorção atômica, métodos estes citados em SARRUGE e HAAG (1974), enquanto que o enxofre foi determinado por tur bidimetria de fluxo contínuo (KRUGG et alii, 1977).

A proteína foi calculada, multiplicando - se os teores de nitrogênio por 6,25.

h) Digestibilidade

A digestibilidade "in vitro" da matéria seca da parte aérea foi determinada de acordo com a técnica de TILLEY e TERRY (1963).

i) Análise estatística

A análise estatística preliminar para cada tipo de parâmetro analisado seguiu o esquema conforme o Quadro 6, de acordo com GOMES (1973). 
Quadro 6 - Esquema de análise de variāncia na fase preliminar

Causas da variação

Nitrogênio (N)

Enxofre (S)

Interação (N $\times$

Resỉduo
GL 2 4 8 45

No caso de interação ( $\mathrm{N} \times \mathrm{S}$ ) significativas desdobraram-se os efeitos de enxofre dentro de cada dose de nitrogènio.

Em todos os casos, foram obtidas as equações de regressão de cada característica analisada em função de doses de enxofre, separadamente para cada dose de nitrogê nio, obtendo as equações que são apresentadas graficamente em resultados e discussão.

\section{j) A fonte de $S$}

Utilizou-se o gesso agrícola (sulfato de cálcio) obtido como sub-produto da produção do ácido fosfórico, que é utilizado na fabricação do superfosfato triplo e fosfatos de amônio-MAP e DAP. A análise típica do produto revela os seguintes teores

$$
\begin{aligned}
& \text { CaO (óxido de cálcio) - 30,9\% } \\
& \mathrm{S} \text { (enxofre) - 17,7\% } \\
& \mathrm{P}_{2} \mathrm{O}_{5} \text { (óxido de fósforo) - 0,7\%. }
\end{aligned}
$$




\section{RESULtados E DISCUSSÃO}

4.1. Efeito de doses de $N$ e $S$ na produção de matéria seca

Nas Tabelas 1 e 2 são apresentadas, respectivamente, as produções de matérià seca da parte aérea e raíz de capim Colonião, a $105^{\circ} \mathrm{C}$, obtidas pela aplicação de doses de N e $S$, enquanto que nos Quadros 7 e 8 , as médias destes parâmetros e o resumo da análise de variância.

Analisando-se sobre os dados verifica-se um efeito linear do $\mathrm{N}$ na produção de matéria seca e um efeito quadrá tico do S. Com relação ao nitrogênio, VICENTE CHANDLER et alii (1959) citam que a adubação nitrogenada, talvez seja o fator que mais interfere na produção e qualidade, da planta forrageira; assim, estes autores demonstraram uma resposta linear da produção de matéria seca do capim elefante até o 


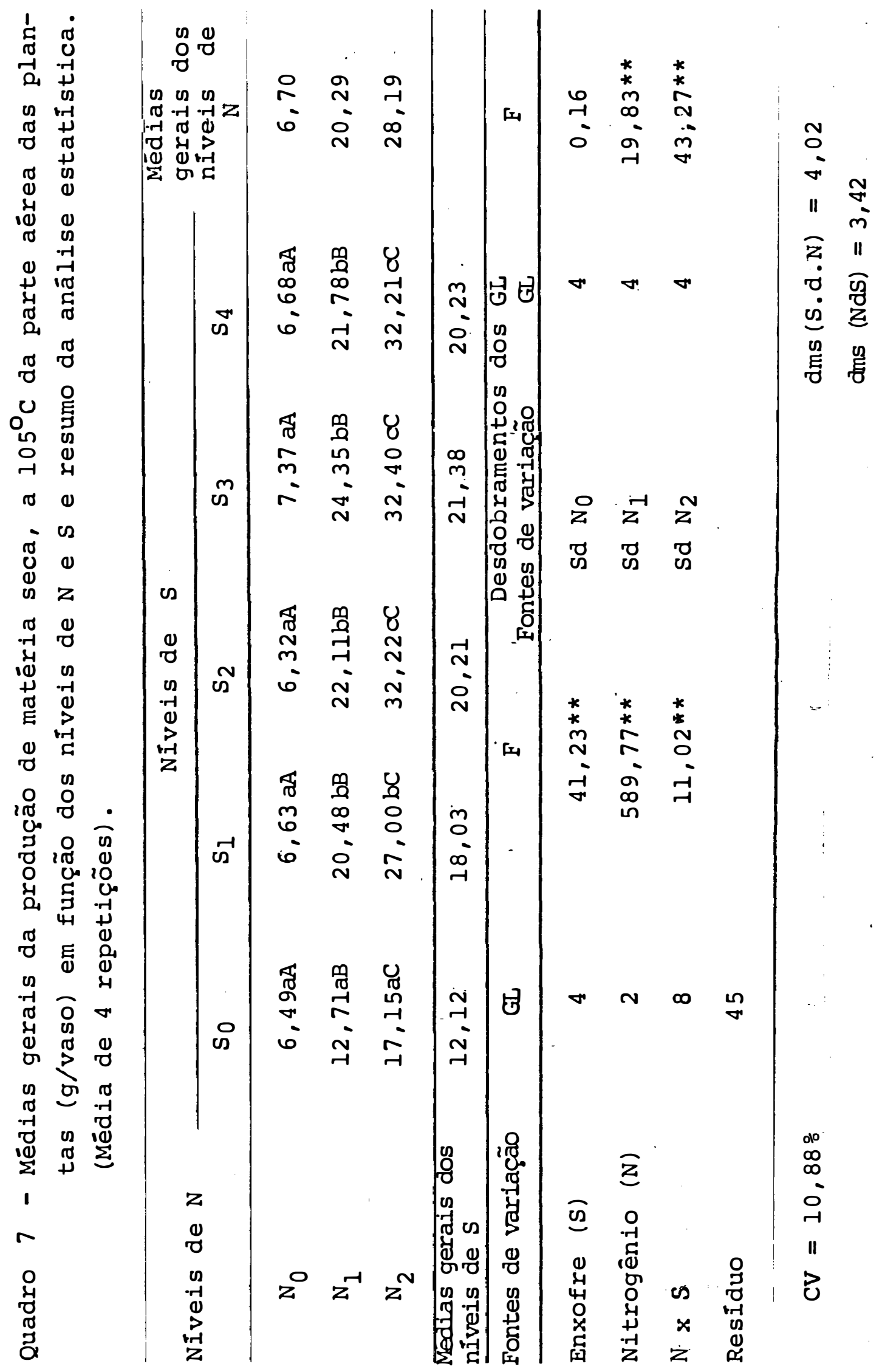




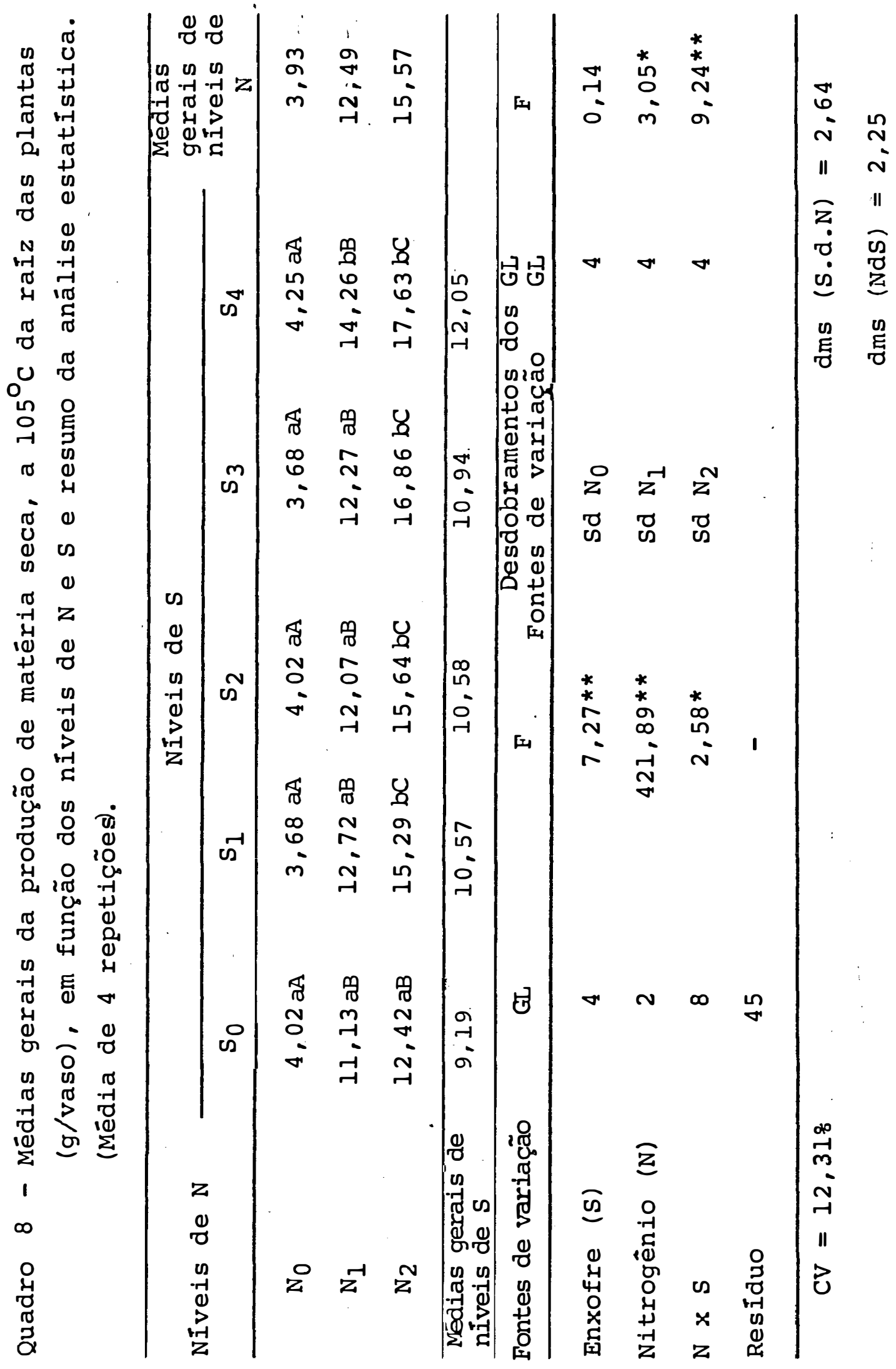


nível de $800 \mathrm{~kg} / \mathrm{ha}$ de $\mathrm{N}$. Respostas positivas à aplicação de S, na forma de gesso em capim colonião, foram também observadas por QUINN et alii (1962) e WENDT (1970). Por outro lado, verifica-se também uma interação $N$ x s significativa, a qual pode ser melhor observada pela análise das Figuras 1 e 2. Assim, nota-se efeito da adição de s na produção de matéria seca do Colonião, somente onde houve adição de fertilização nitrogenada, fato este também observado por McCLUNG e FREITAS (1959), QUINN et alii (1961), JONES (1964), os quais notaram que não havia resposta significativa quando o enxôfre era o único elemento aplićado, e essa só ocorria em presença de níveis adequados de $\mathrm{N}$ e $\mathrm{P}$.

Utilizando-se das respectivas equações de regressão apresentadas na Figura 1 , obtém-se que as doses de $\mathbf{S}$ que permitiram máxima produção de matéria seca da parte aérea de capim colonião variaram de 55 a $60 \mathrm{~kg} / \mathrm{ha}$ de $\mathrm{s}$, respectivamente, para as doses de 100 e $200 \mathrm{~kg} / \mathrm{ha}$ de N. QUINN et alii (1961) também registraram benefícios decorrentes da aplicação de $60 \mathrm{~kg} / \mathrm{ha}$ de $\mathrm{S}$, na forma de gesso, sobre a capacidade de suporte da pastagem e produção de carne/ha em colonião adubado com $200 \mathrm{~kg} / \mathrm{ha}$ de $\mathrm{N}$ e $200 \mathrm{~kg} / \mathrm{ha}$ de $\mathrm{P}_{2} \mathrm{O}_{5}$, enquanto que McCLUNG et alii (1950) estudando o efeito de doses crescentes de $\mathrm{S}$ em Pennisetum glaucum, obtiveram respostas máximas pela aplicação de $20 \mathrm{~kg} / \mathrm{ha}$ de s. Já, CASAGRANDE e CORREA DE SOUzA verificaram que a maior resposta ao enxôfre deu-se com a apli- 


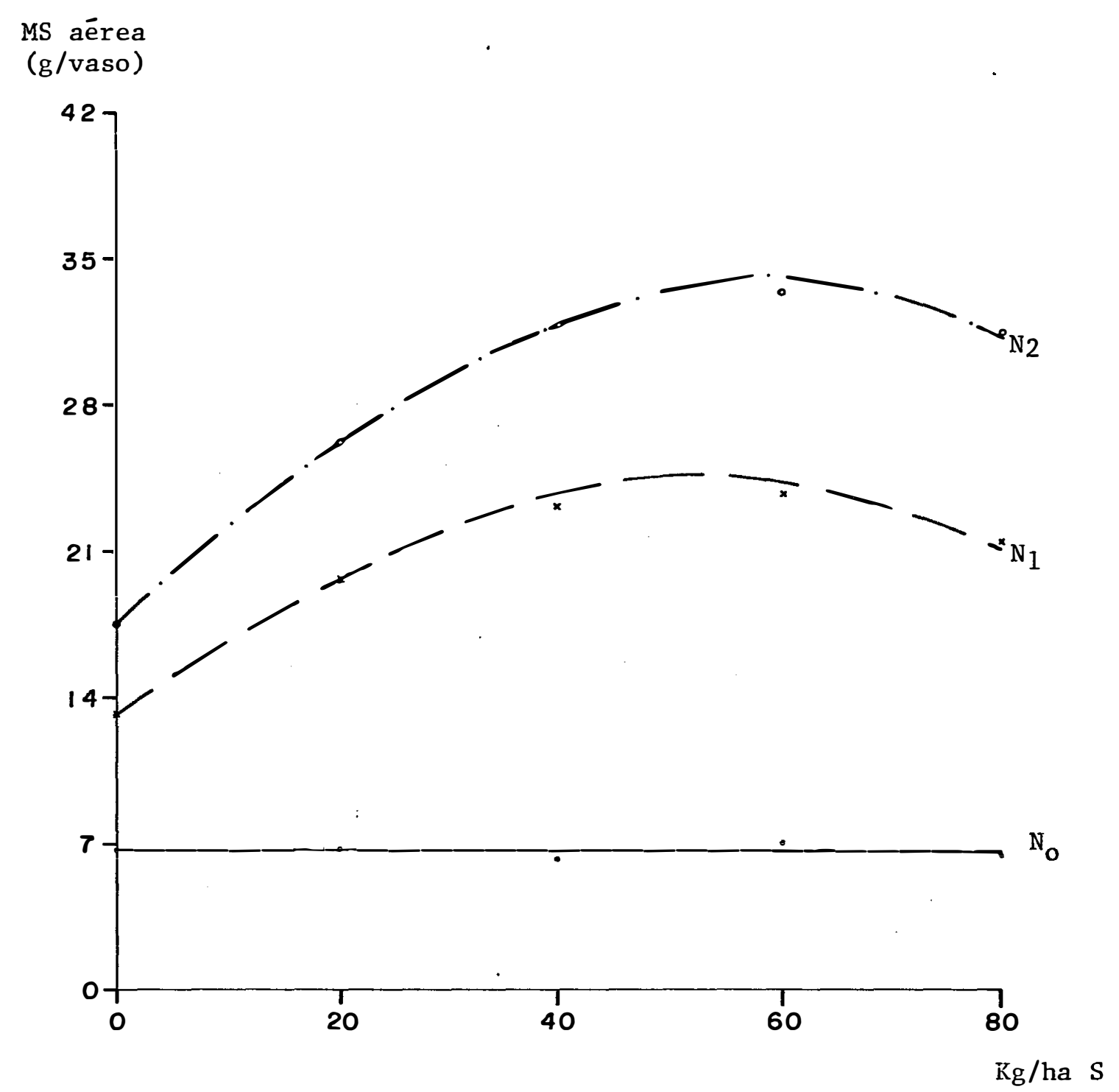

$$
\begin{aligned}
& \text { No } \longrightarrow \text { Y }=6,699 \text { (a) } \\
& N_{1}-\stackrel{x}{-} \mathrm{Y}=13,02+0,397 x-0,00358 x^{2} \quad R^{2}=0,97 * * \\
& \text { N2 }-.-17=17,50+0,537 x-0,00449 x^{2} \quad R^{2}=0,98 * *
\end{aligned}
$$

Figura 1 - Efeito de doses de $S$ na produção de matéria seca (g/vaso) da parte aérea, em cada nível de $\mathrm{N}$ utilizado. 


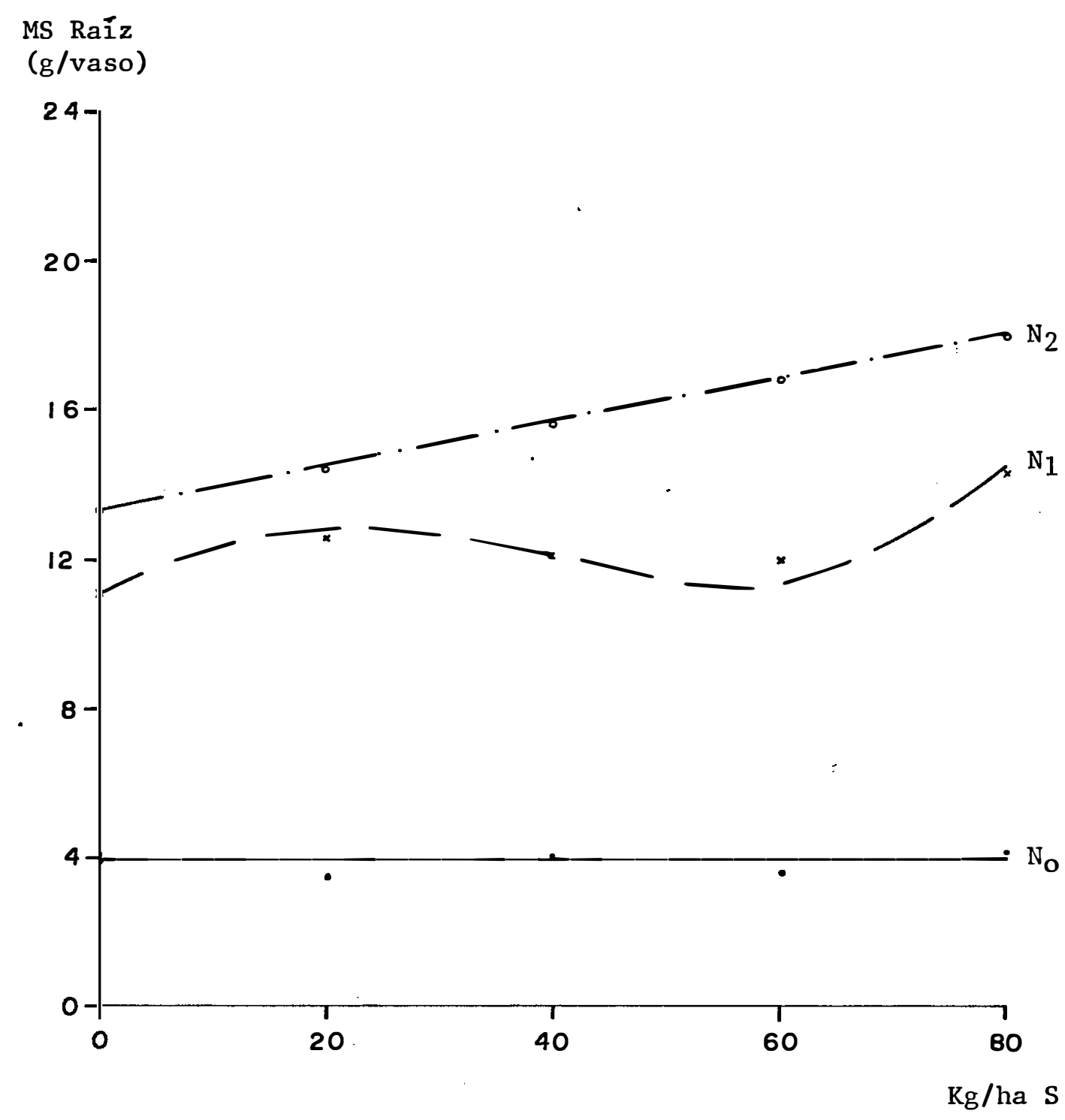

$$
\begin{aligned}
& \text { No } \quad \mathrm{Y}=3,933 \\
& \text { NI }-x-Y=11,14+0,152 x-0,0048 x^{2}+0,00004 x^{3} \quad R^{2}=0,95 * * \\
& \mathrm{~N}_{2}-\cdot+-\mathrm{Y}=13,216+0,0592 \mathrm{x} \quad \mathrm{r}^{2}=0,91 * *
\end{aligned}
$$

Figura 2 - Efeito de dọses de $S$ na produção de matéria seca (g/vaso) da raiz em cada nível de $\mathrm{N}$ utilizado. 
cação de $30 \mathrm{~kg} / \mathrm{ha}$ de $\mathrm{s}$, utilizando-se como plantas testes, capim gordura, jaraguá, braquiāria e setária (solo de cerrado) .

\subsection{Efeito dos tratamentos sobre a concentração e quanti-} dade absorvida de $N, P, S$ e Ca

Nas Tabelas de 3 a 6 são apresentadas, respectivamente, as concentrações de N, P, S e Ca em porcentagem de ma téria seca a $105^{\circ} \mathrm{C}$, enquanto que nas de 7 a 10 , as quantidades respectivas desses nutrientes absorvidas em mg/vaso. As médias gerais desses parâmetros, bem como o resumo da análise de variância são apresentadas, respectivamente, nos Quadros de 9 a 16 e Figuras 3 a 10.

Com relação às concentrações de $\mathrm{N}$ na matéria seca observa-se aumento nas mesmas com o aumento das doses de $\mathrm{N}$ empregadas, passando de 0,87 (nível $\mathrm{N}_{\mathrm{O}}$ ) para 1,63\% $\mathrm{N}$ (nível $\mathrm{N}_{2}$ ), enquanto que o enxôfre aplicado não promoveu aumento na concentração de $\mathrm{N}$ (Quadro 9 e Figura 4). Já o teor de $\mathrm{P}$ reve lou uma diminuição com o aumento de doses de $\mathrm{N}$, muito provavel mente devido a um efeito de diluição, e um aumento apenas na dose mais elevada de $S$ enpregada (Quadro 10 e Figura 5). O teor, de enxôfre na parte aérea teve um aumento com as doses de $S$ "utilizadas, revelando uma interação positiva entre esses dois nutrientes (Suadro 11 e Figura 3), enguanto que o teor de cálcio aumentou com as doses de enxôfre na forma de gesso, revelando que essa fonte 


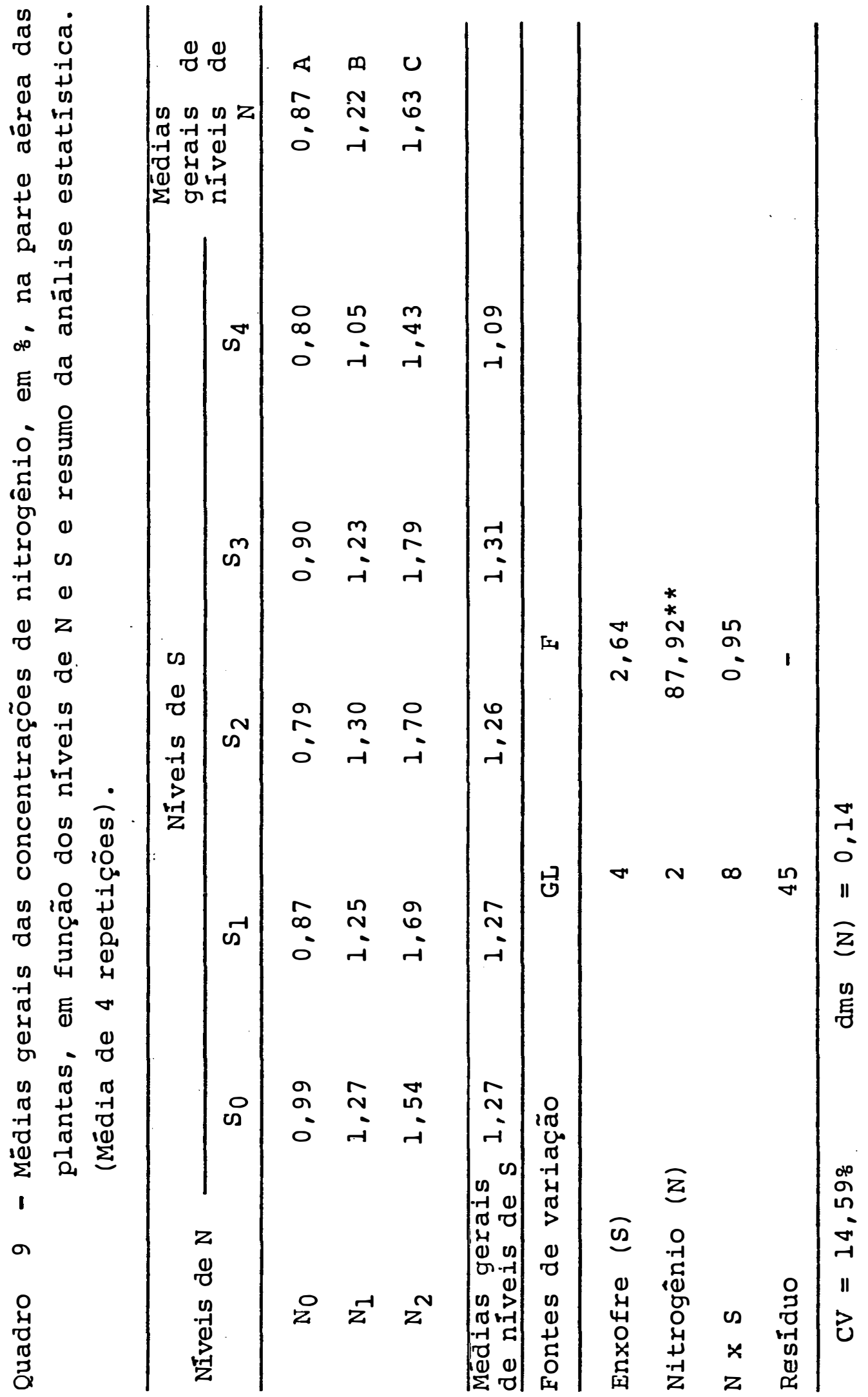




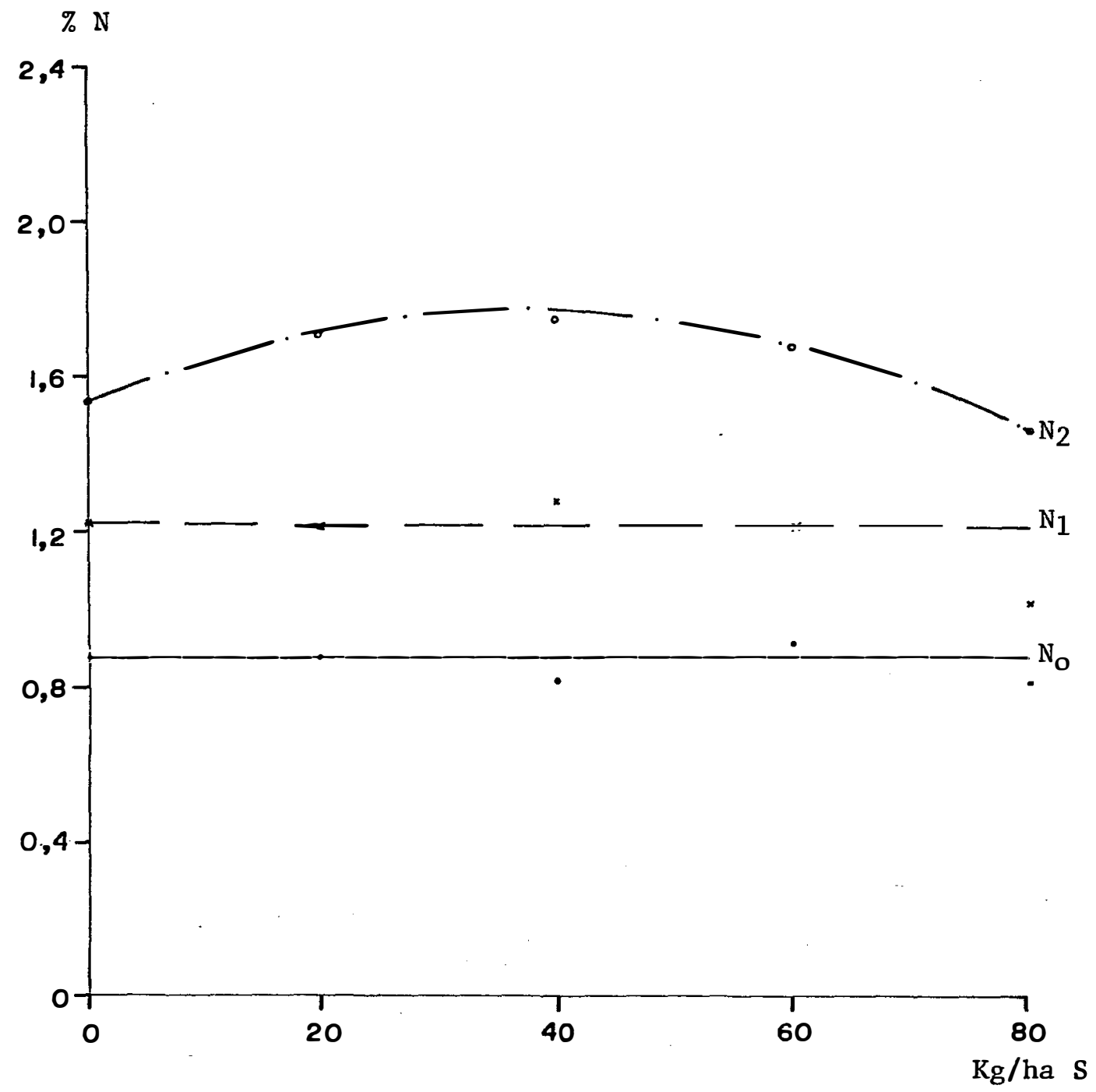

$$
\begin{aligned}
& \text { No }-\mathrm{Y}=0,872 \\
& \mathrm{~N}_{1}-\frac{\mathrm{x}-\mathrm{Y}=1,219}{\mathrm{~N}_{2}-\cdot--\mathrm{Y}=1,523+0,0127 \mathrm{x}-0,00017 \mathrm{x}^{2} \quad \mathrm{R}^{2}=0,79 * *}
\end{aligned}
$$

Figura 4 - Efeito de doses de $\mathrm{S}$ na concentração de $\mathrm{N}$ da parte aérea, em cada nível de $\mathrm{N}$ utilizado. 


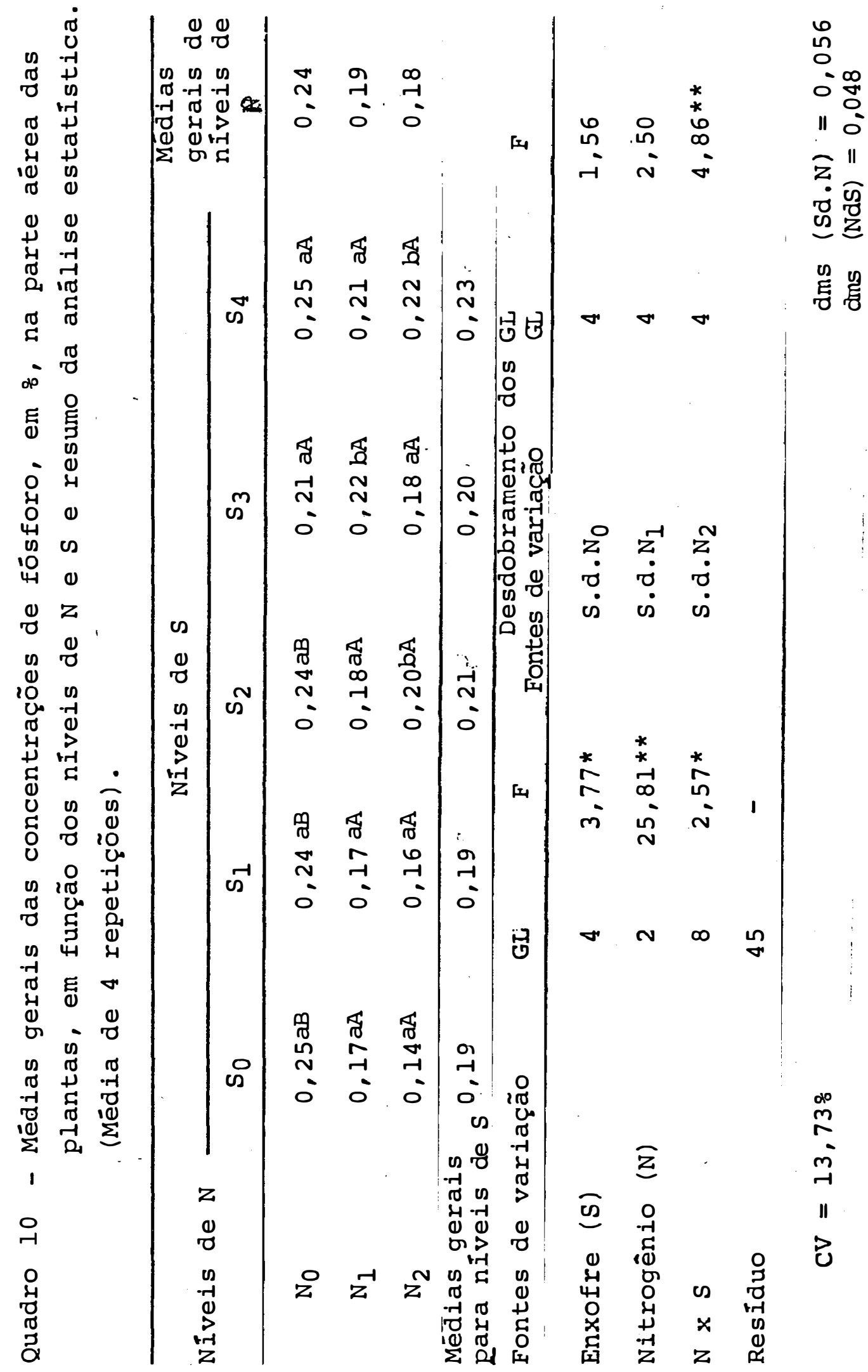




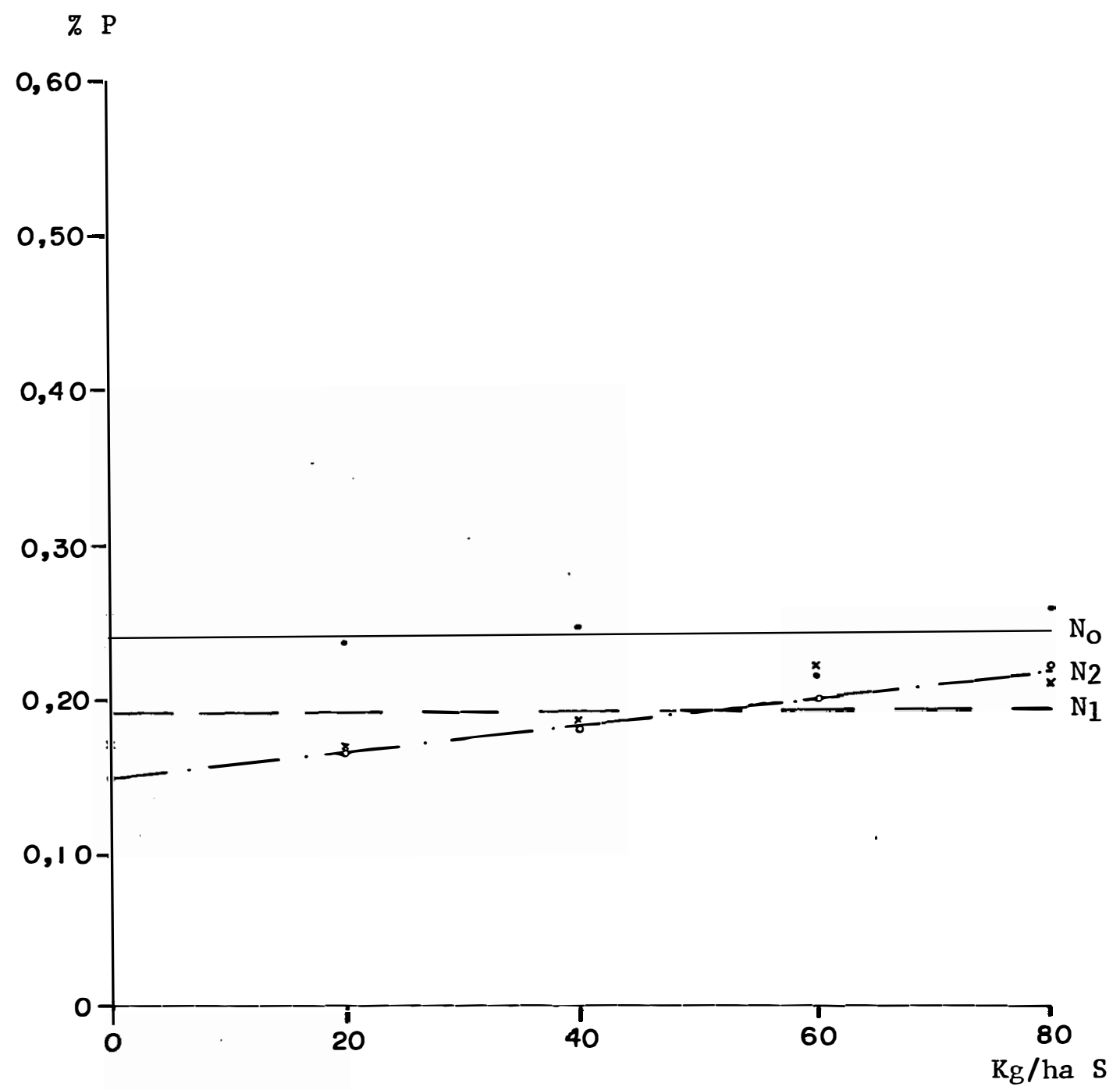

$$
\begin{aligned}
& \text { No } \mathrm{Y}=0,241 \\
& \text { N1 }-\mathrm{Y}=0,190 \\
& \text { N2 }-\cdot \circ-\mathrm{Y}=0,148+0,00085 \mathrm{x} \quad \mathrm{r}^{2}=0,76 * *
\end{aligned}
$$

Figura 5 - Efeito de doses de $S$ na concentração de $\mathrm{P}$ das folhas, em cada nível de. $\mathrm{N}$ utilizado. 


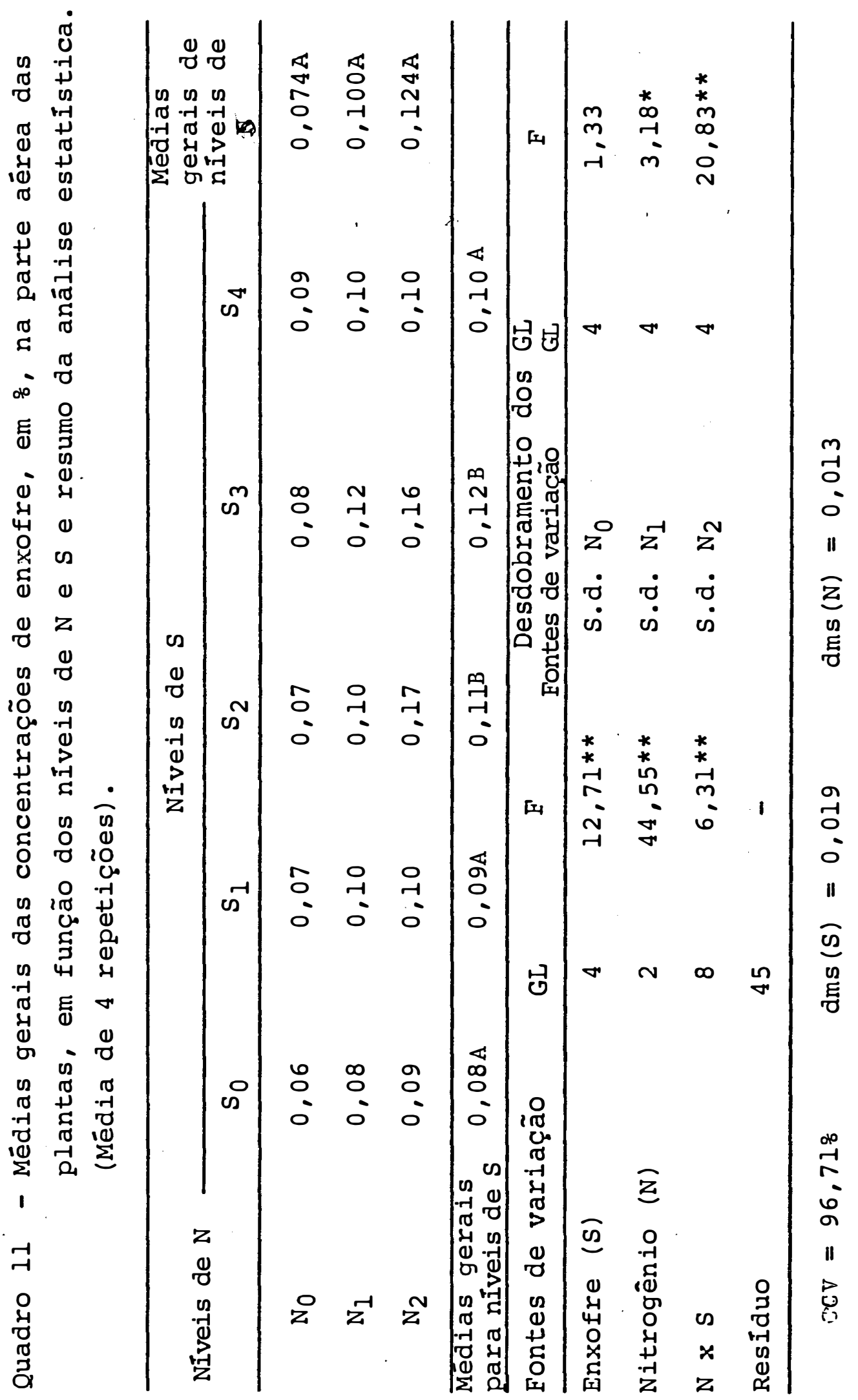




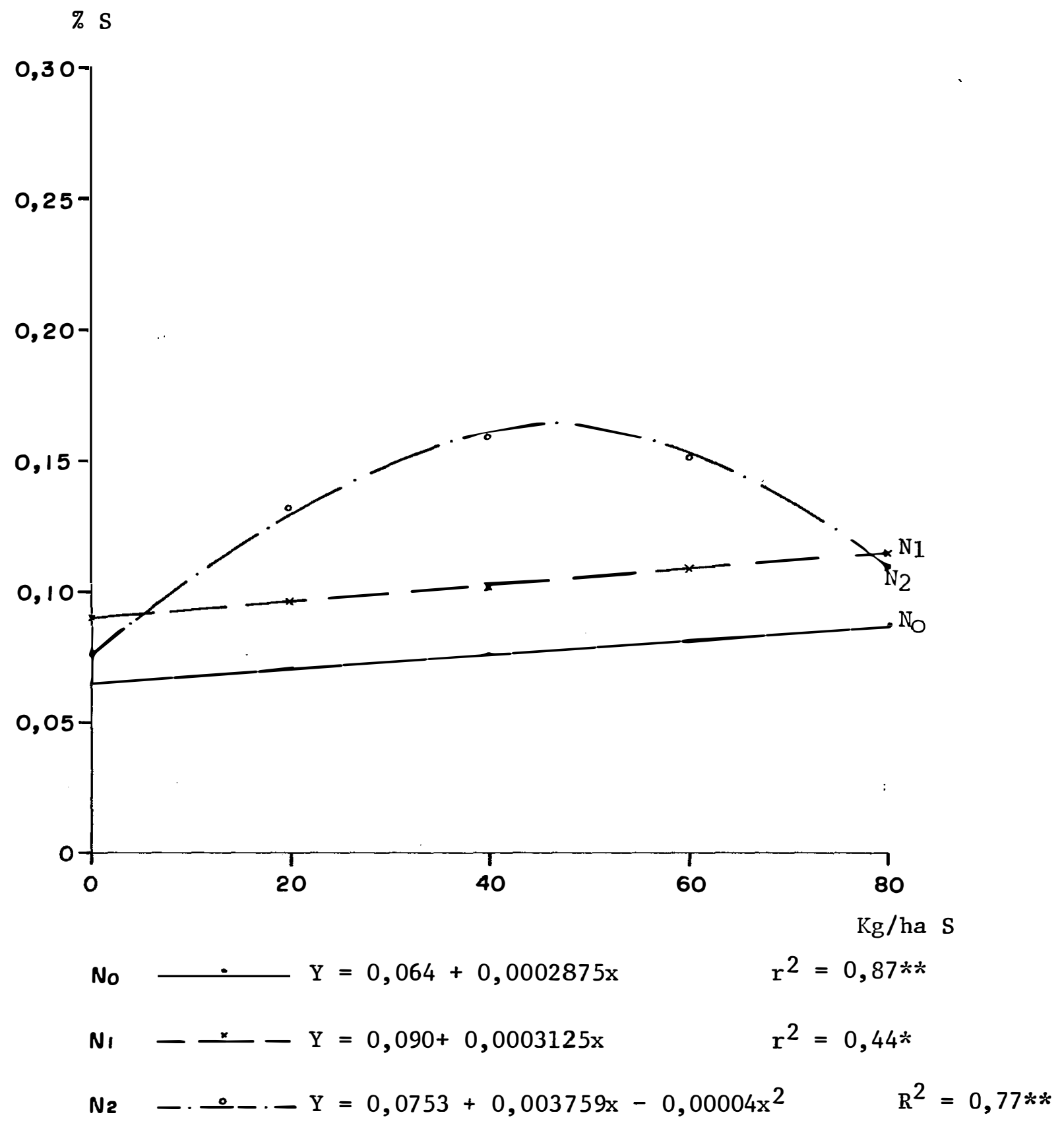

Figura 3 - Efeito de doses de $S$ na concentração de $S$ das folhas, em cada nível de $\mathrm{N}$ utilizado. 


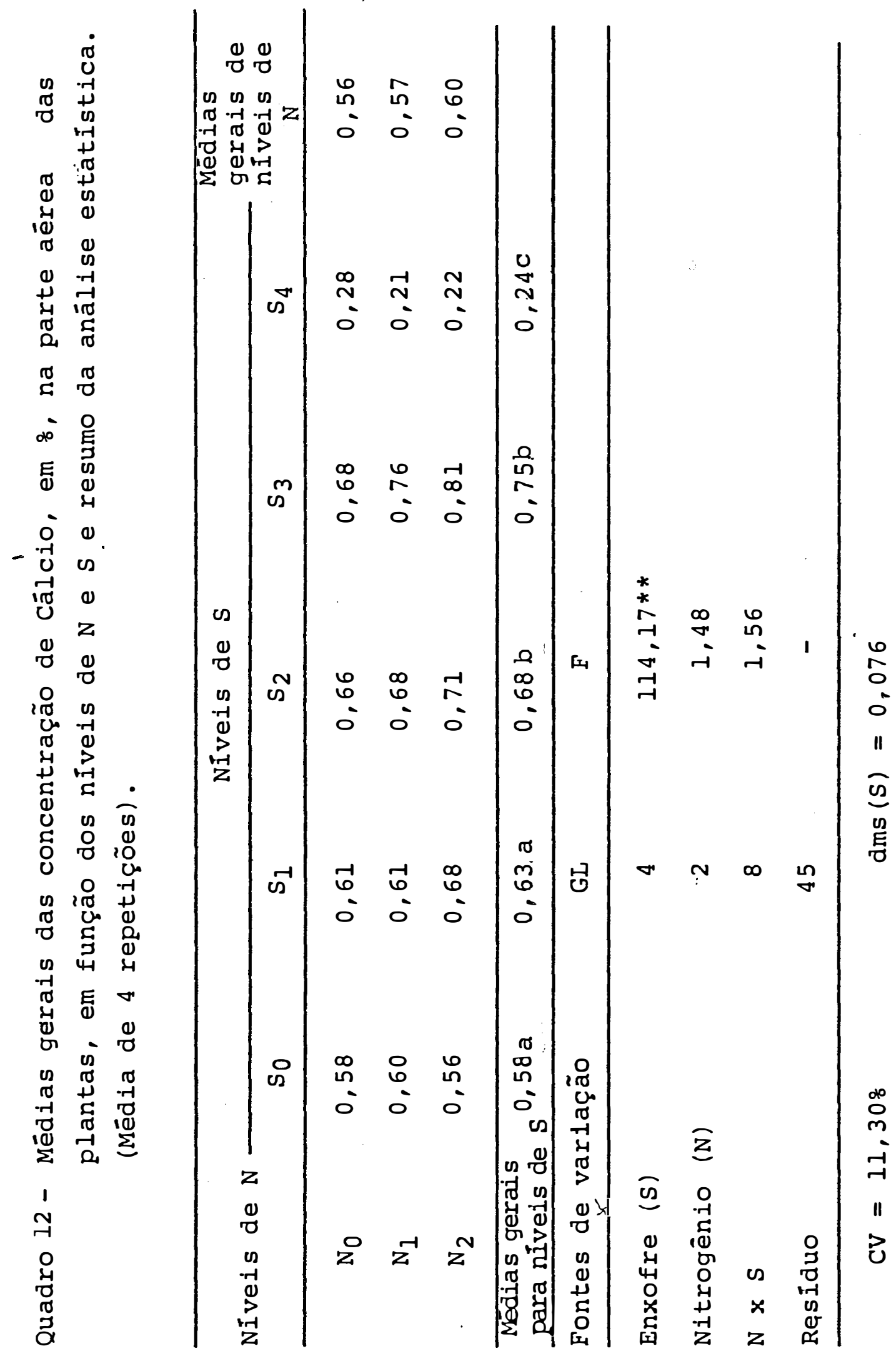




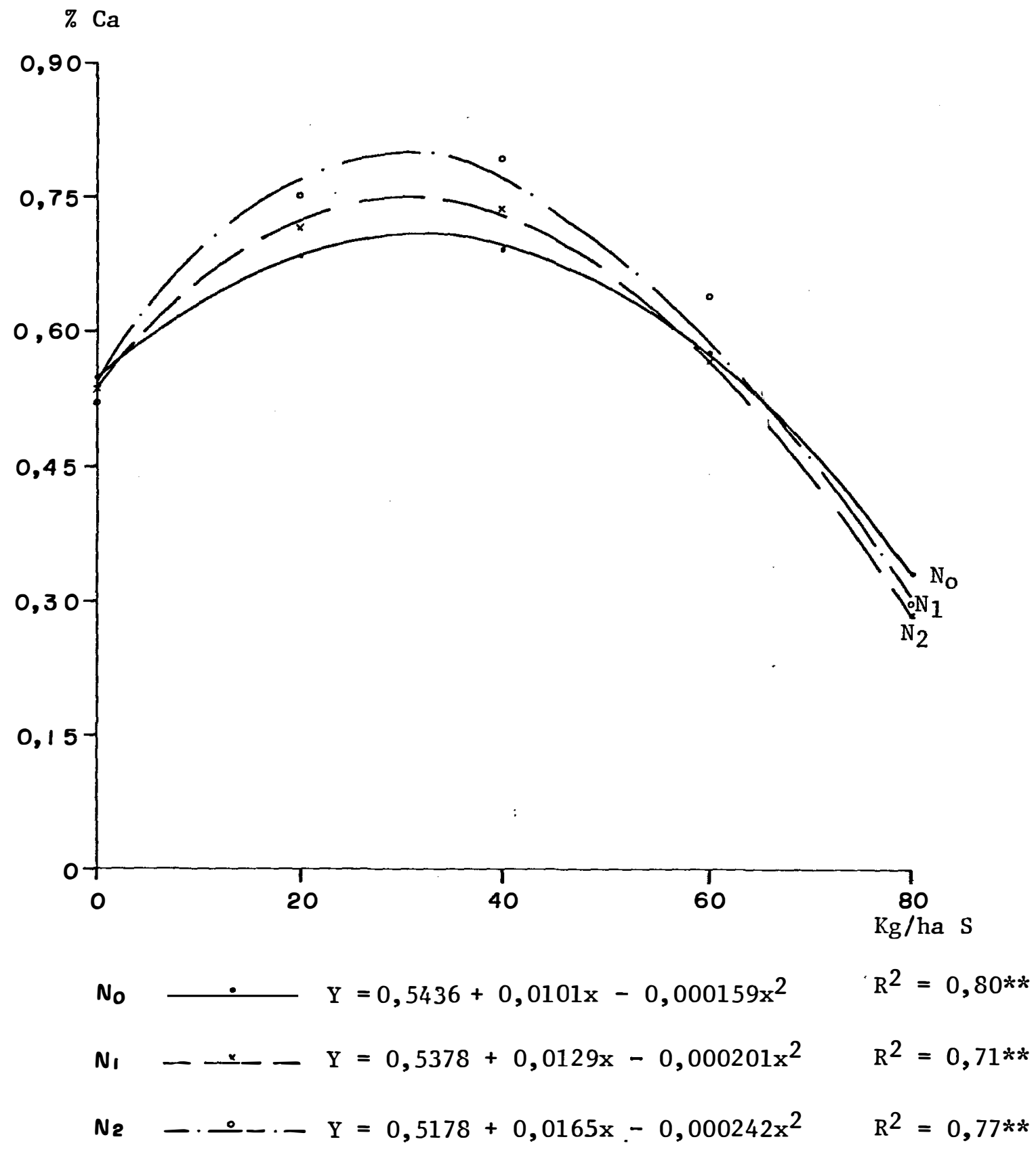

Figura 6 - Efeito de doses de S, na concentração de Ca das folhas, em cada nível de $\mathrm{N}$ utilizado. 
funcionou também como fonte de cálcịo (Quadro 12 e Figura 6).

Comparando a faixa de teores de N, P, S e Ca encontrados na matéria seca da parte aérea do capim colonião verifica-se que HAAG et alii (1967) encontraram valores, respec tivamente, de 1,71; 0,20;0,09 e 0,29\%, enquanto que ZAGO e GOMIDE (1982), encontraram valores médios aos 63 dias de desen volvimento para Ca e P de 0,30 e 0,16\% . Já, FRENCH e CHAPARRO (1960) citam valores de 0,13 a 0,47\% para o Ca, e afirmam que valores menores do que $0,20 \%$ são deficientes para $\circ \mathrm{P}$, enquan to que $0,1 \%$ para $S$ é suficiente segundo NRC (1976). Ora, no presente ensaio verifica-se que para o $N$, somente no nível $\mathrm{N}_{0}$ o mesmo encontra-se com valores muito baixos, enquanto que os teores de $\mathrm{P}$ estão próximos dos citados, o S está deficiente no nível $N_{0}$ e nos níveis $S_{0}$ e $S_{l}$, enquanto que o $C a$ está nos limites citados.

Evidentemente que muito mais importante para verificar os efeitos de doses de $\mathrm{N}$ e $\mathrm{S}$ utilizadas bem como de suas interações, são as quantidades dos nutrientes absorvidos pelas plantas. Assim, quando são utilizados esses parâmetros (Quadros 13 a 16.e Figuras 7 a 10), nota-se um comportamento dos tratamentos semelhante ao observado em relação à produção de matéria seca, ou seja, nos tratamentos onde a produção foi maior, ocorreu maior absorção de N, P, S e Ca, indicando não só a eficiência das fontes no fornecimento de N, S e Ca, bem 


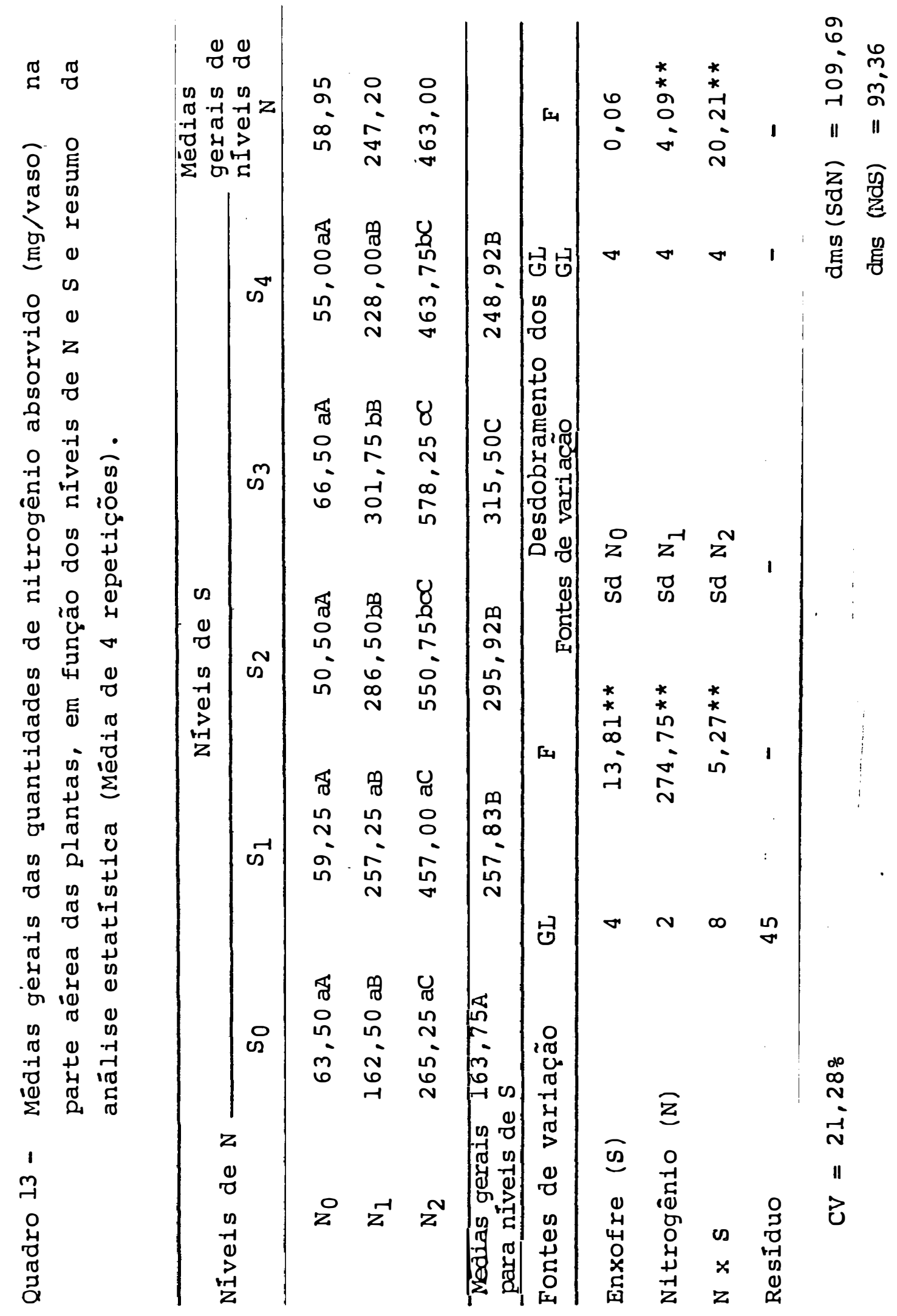




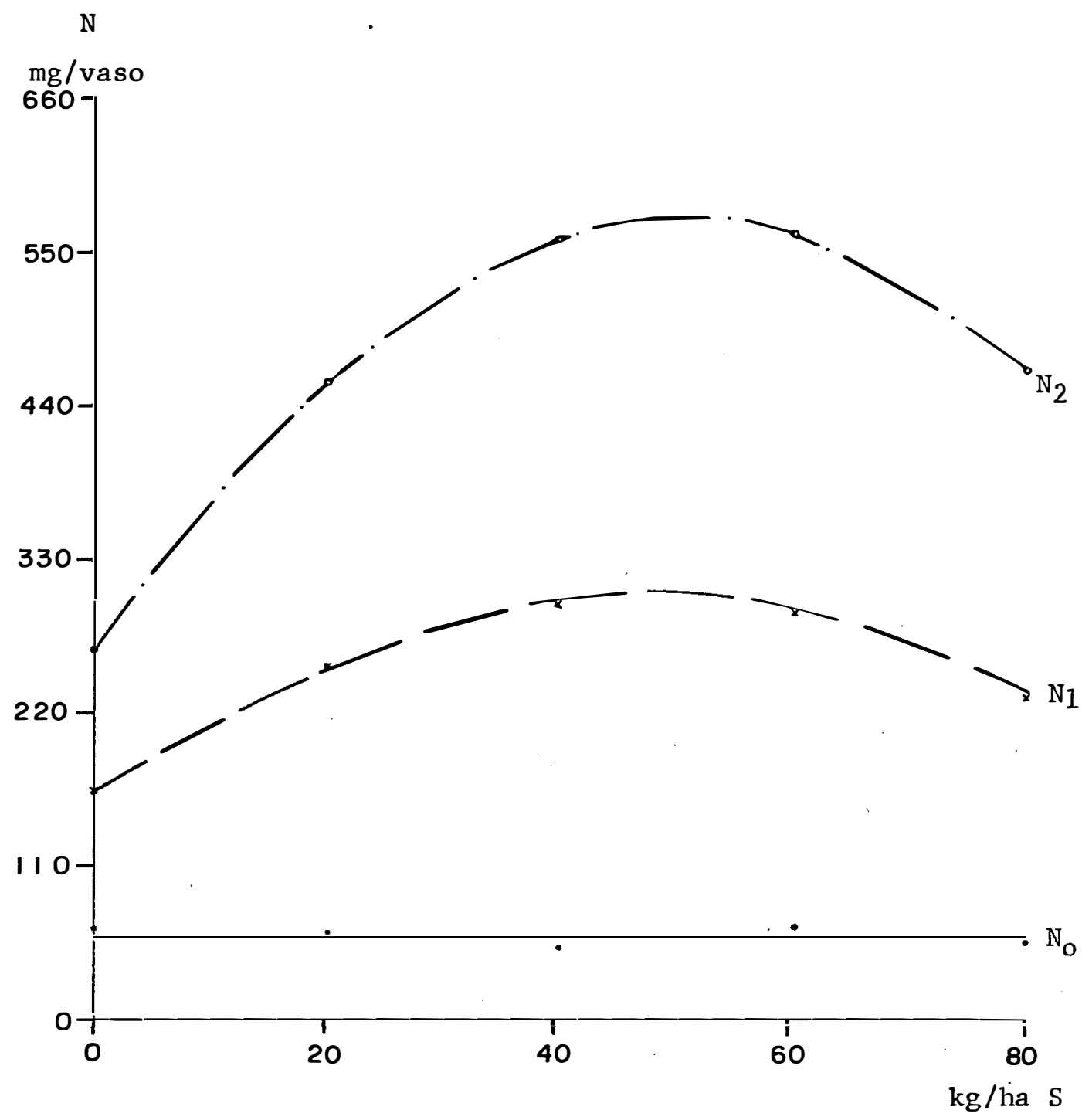

$$
\begin{array}{ll}
\text { No }-\mathrm{Y}=58,95 & \\
\text { N1 }-+\mathrm{x}-\mathrm{Y}=161,957+5,892 \mathrm{x}-0,0627 \mathrm{x}^{2} & \mathrm{R}^{2}=0,97 * * \\
\text { N2 }_{2}-\cdots \mathrm{-}-\mathrm{Y}=262,385+12,287 \mathrm{x}-0,121 \mathrm{x}^{2} & \mathrm{R}^{2}=0,99 * *
\end{array}
$$

Figura 7 - Efeito de doses de $\mathrm{S}$, na quantidade de nitrogênio extraída por vaso, em cada nível de $\mathrm{N}$ utilizado 


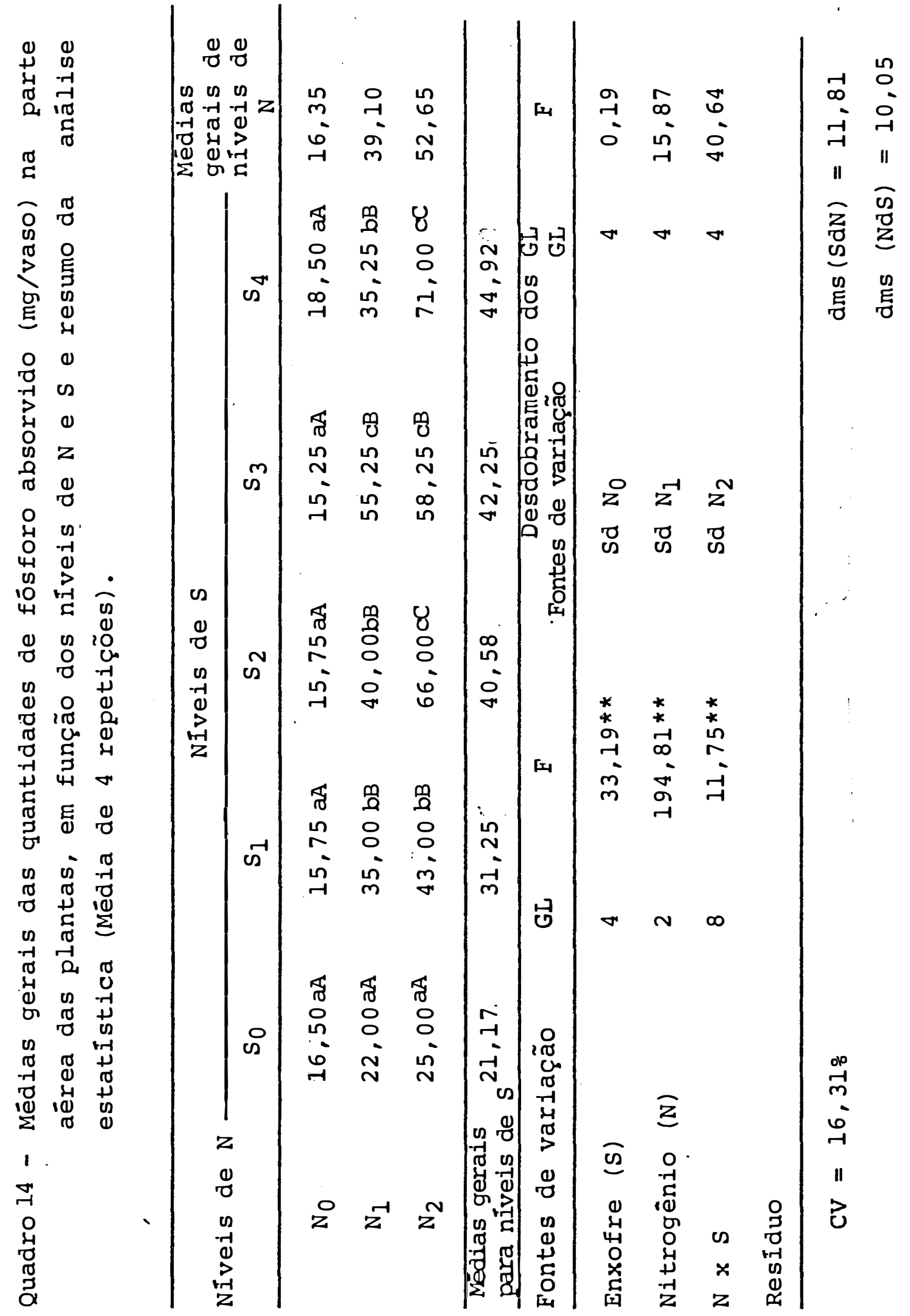




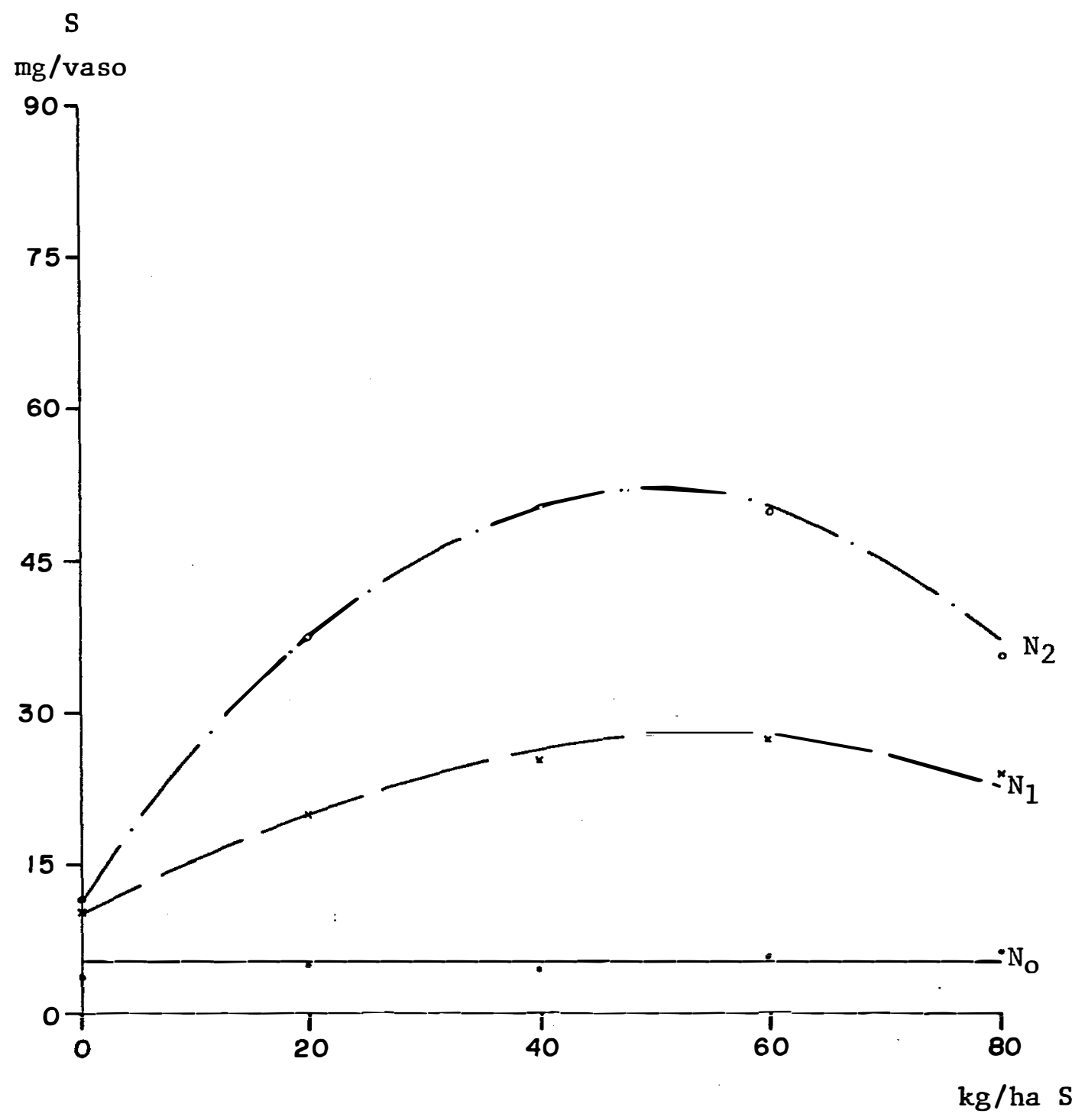

$$
\begin{array}{ll}
\text { No }-\mathrm{Y}=5,15 & \\
\mathrm{~N}_{1}-\mathrm{x}=10,41+0,584 \mathrm{x}-0,00518 \mathrm{x}^{2} & \mathrm{R}^{2}=0,86 * * \\
\mathrm{~N}_{2}-\mathrm{O}-\mathrm{Y}=11,18+1,664 \mathrm{x}-0,0169 \mathrm{x}^{2} & \mathrm{r}^{2}=0,87 * *
\end{array}
$$

Figura 8 - Efeito de doses de $S$, na quantidade de enxofre extraída por vaso, em cada nível de $\mathrm{N}$ utilizado. 


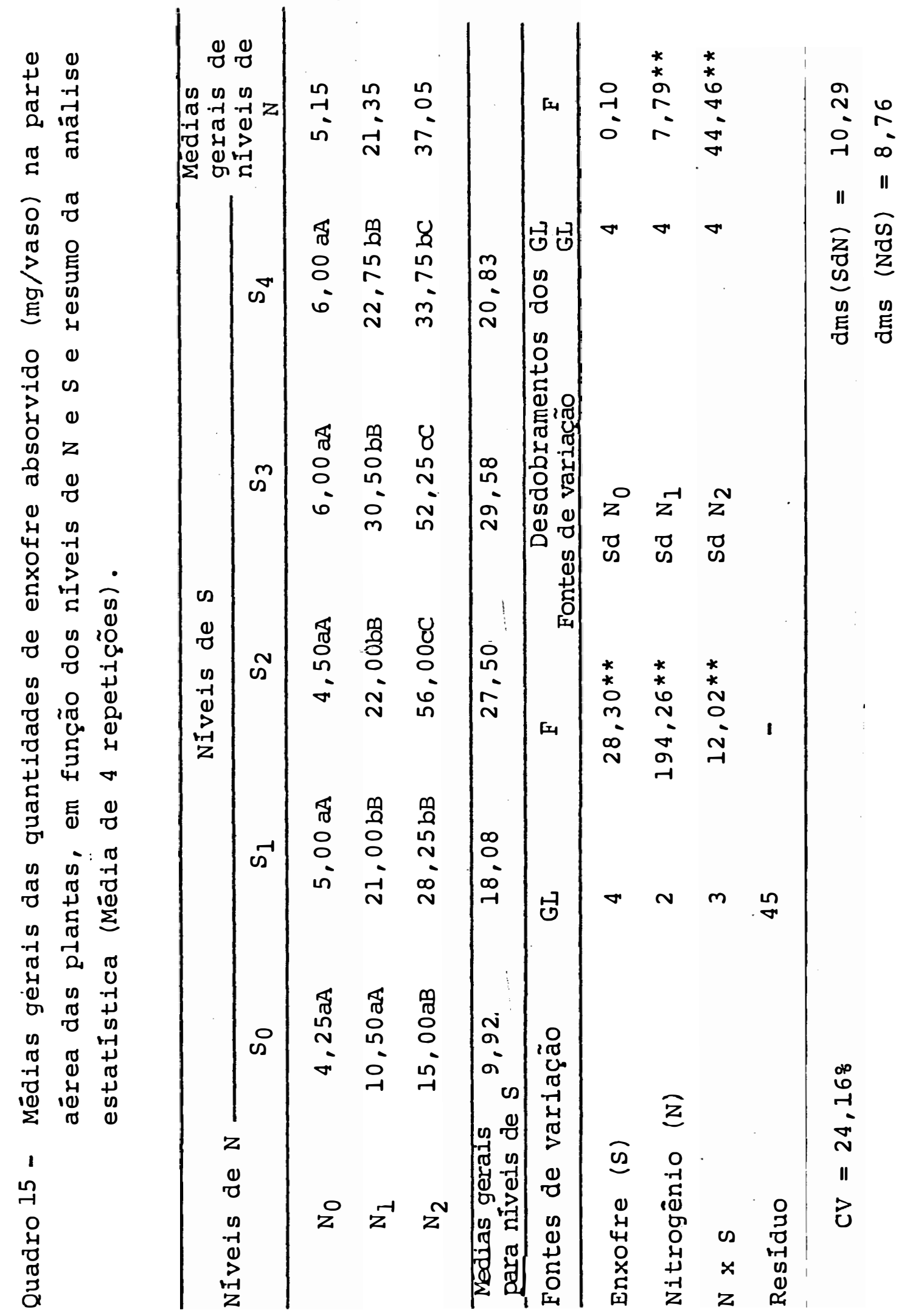




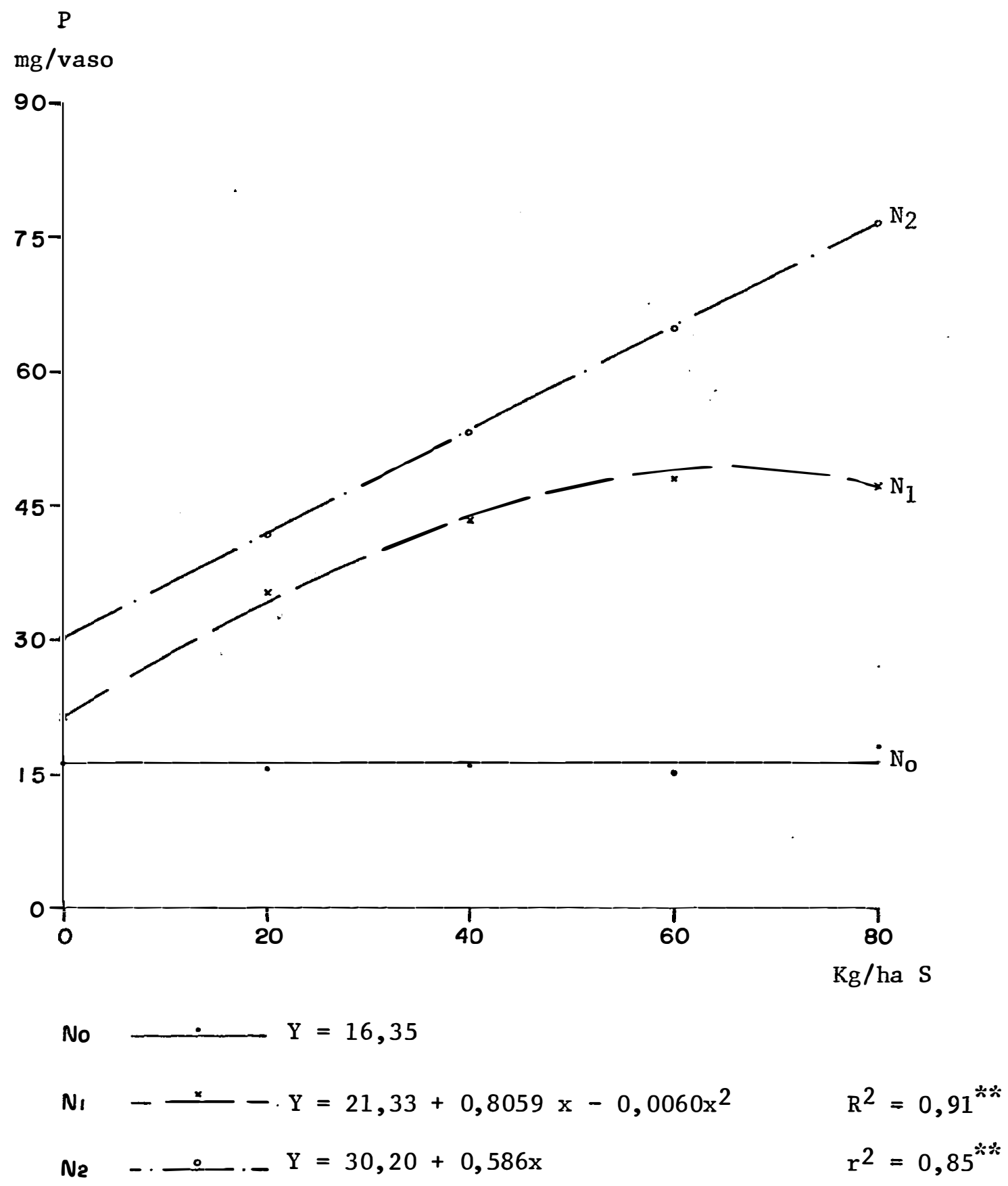

Figura 9 - Efeito de doses de $S$, na quantidade de fósforo extraída por vaso, em cada nível de $\mathrm{N}$ utilizado. 


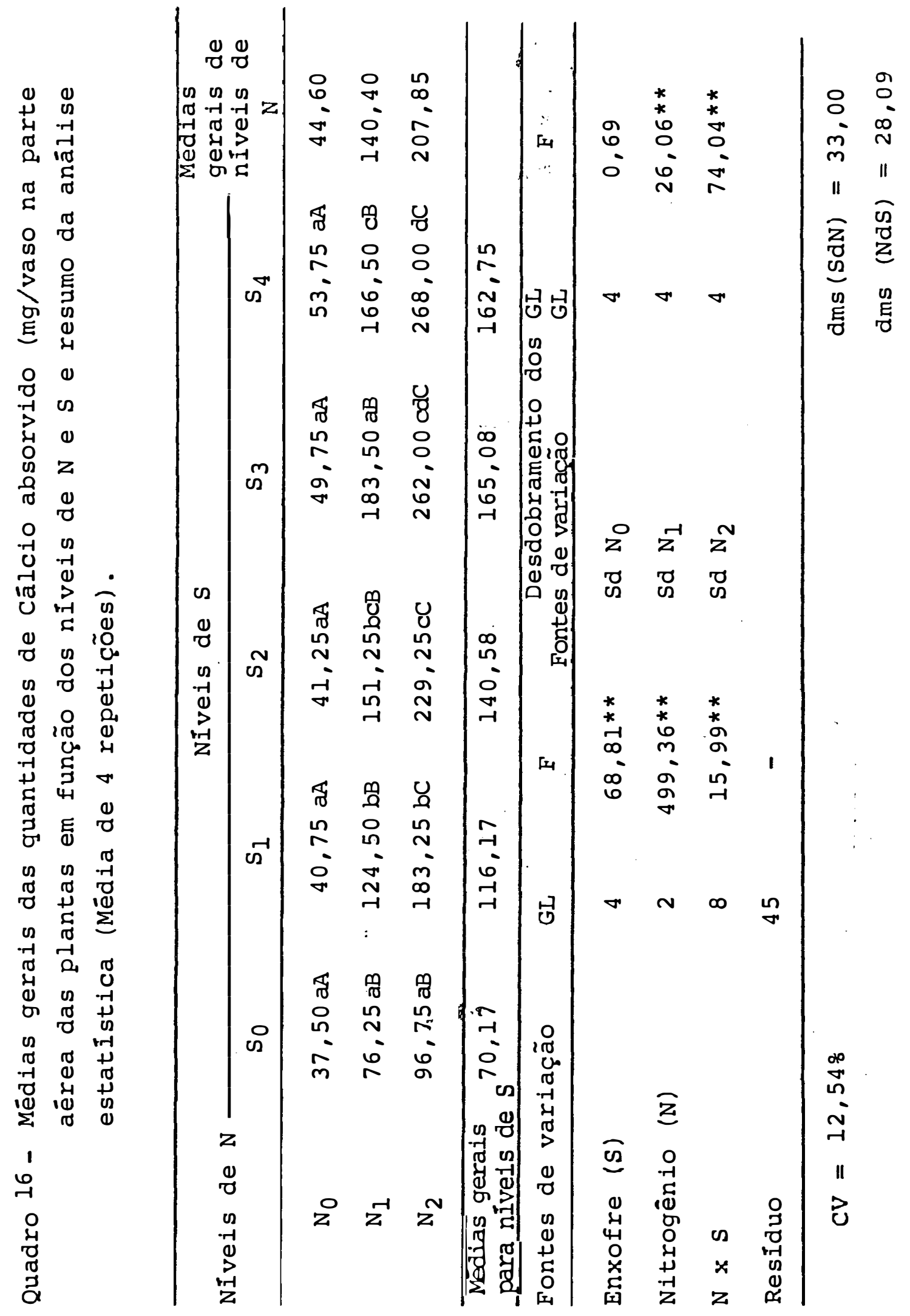




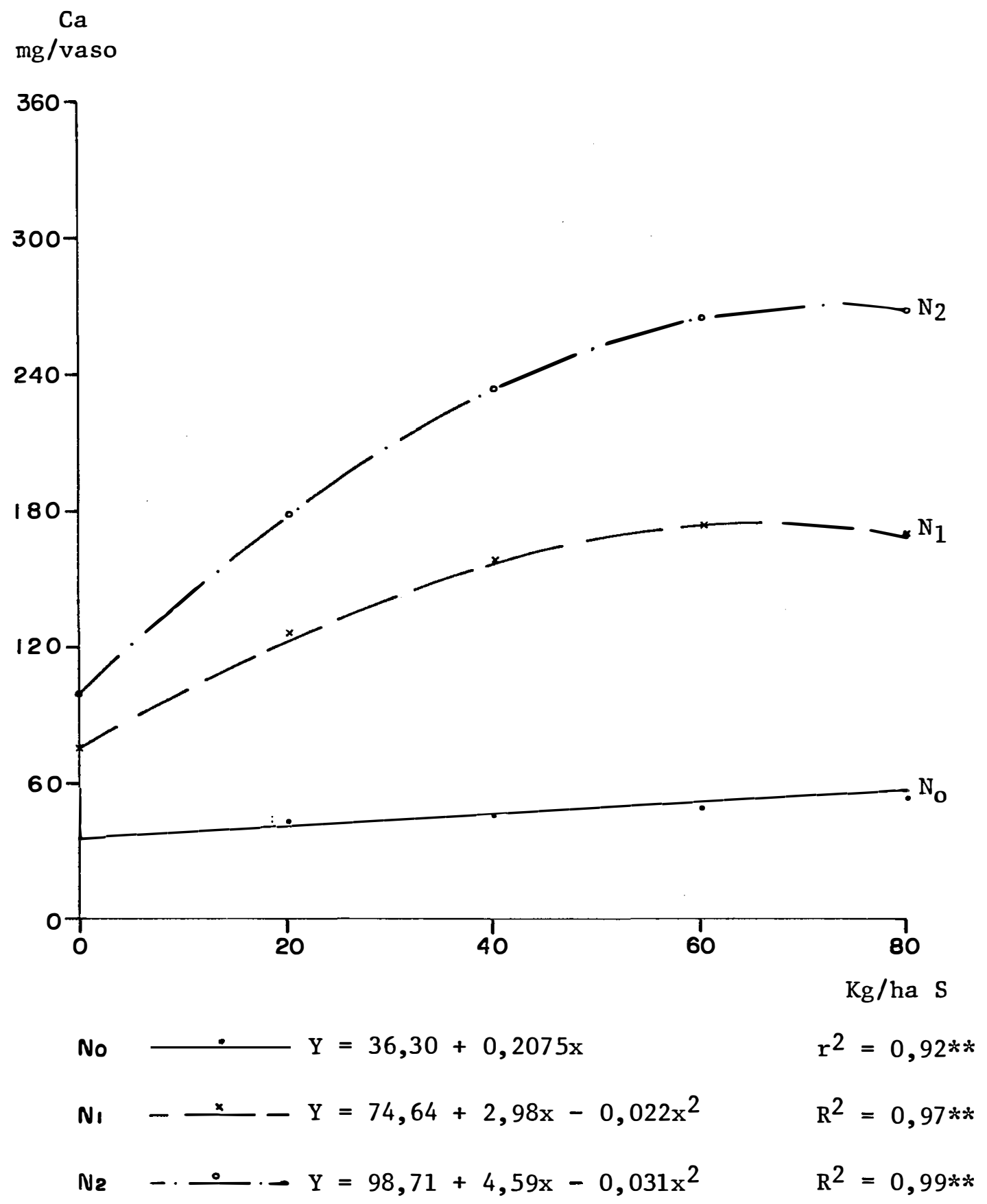

Figura 10 - Efeito de doses de S, na quantidade de cálcio extraída por vaso, em cada nível de $\mathrm{N}$ utilizado 
como uma interação positiva entre os nutrientes. Assim, pela análise da Figura 7, observa-se um aumento quadrático. na quantidade de $\mathbf{N}$ absorvido com aumento das doses de $\mathrm{S}$ utiliza das, atingindo uma quantidade máxima de $\mathrm{N}$ absorvido, ao redor da dose de $50 \mathrm{kh} / \mathrm{ha}$ de $\mathrm{S}$. Também as quantidades absorvidas por vaso de S, P e Ca (Figuras 8, 9 e 10) foram afetadas significa tiva e positivamente pela interação $N \times S$.

\subsection{Efeito dos tratamentos sobre as relações N/S; P/S;} e $N / P$

o substrato de desenvolvimento de uma planta deve apresentar um adequado balanço iônico para os macronutrientes aniônicos N, P e S, refletindo assim, relações sobre os mesmos nas plantas benéficas ou preju'diciais a produção e qua lidade do produto obtido. As relações N/S; P/S; e N/P da parte aérea das plantas acham-se, respectivamente, nas Tabelas 11 , 12 e 13, enquanto que nos Quadros 17, 18 e 19, são apresentadas as médias com o resumo da anālise estatística.

De uma maneira geral observa-se uma diminuição da relação $\mathrm{N} / \mathrm{S}$ com $O$ aumento dos níveis de $S$, uma diminuição da relação $\mathrm{P} / \mathrm{S}$ com $O$ aumento dos níveis de $\mathrm{N}$ e $\mathrm{S}$, e um aumento da relação $\mathrm{N} / \mathrm{P}$ com $O$ aumento de doses de $\mathrm{N}$ e uma diminuição com as doses de $S$. Esses resultados são melhores eviden ciados pela análise das Figuras 11, 12 e 13. Assim, para as 


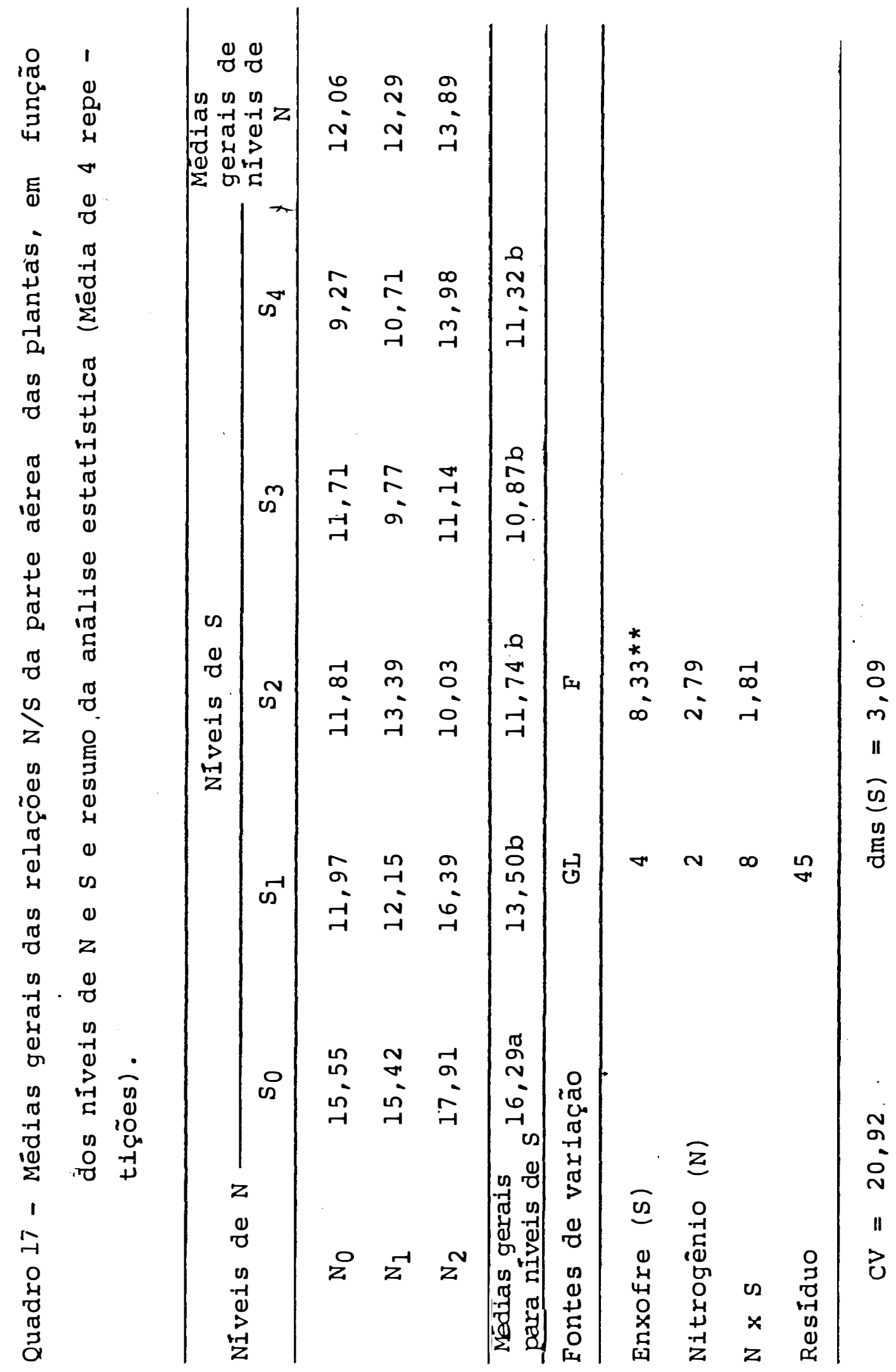




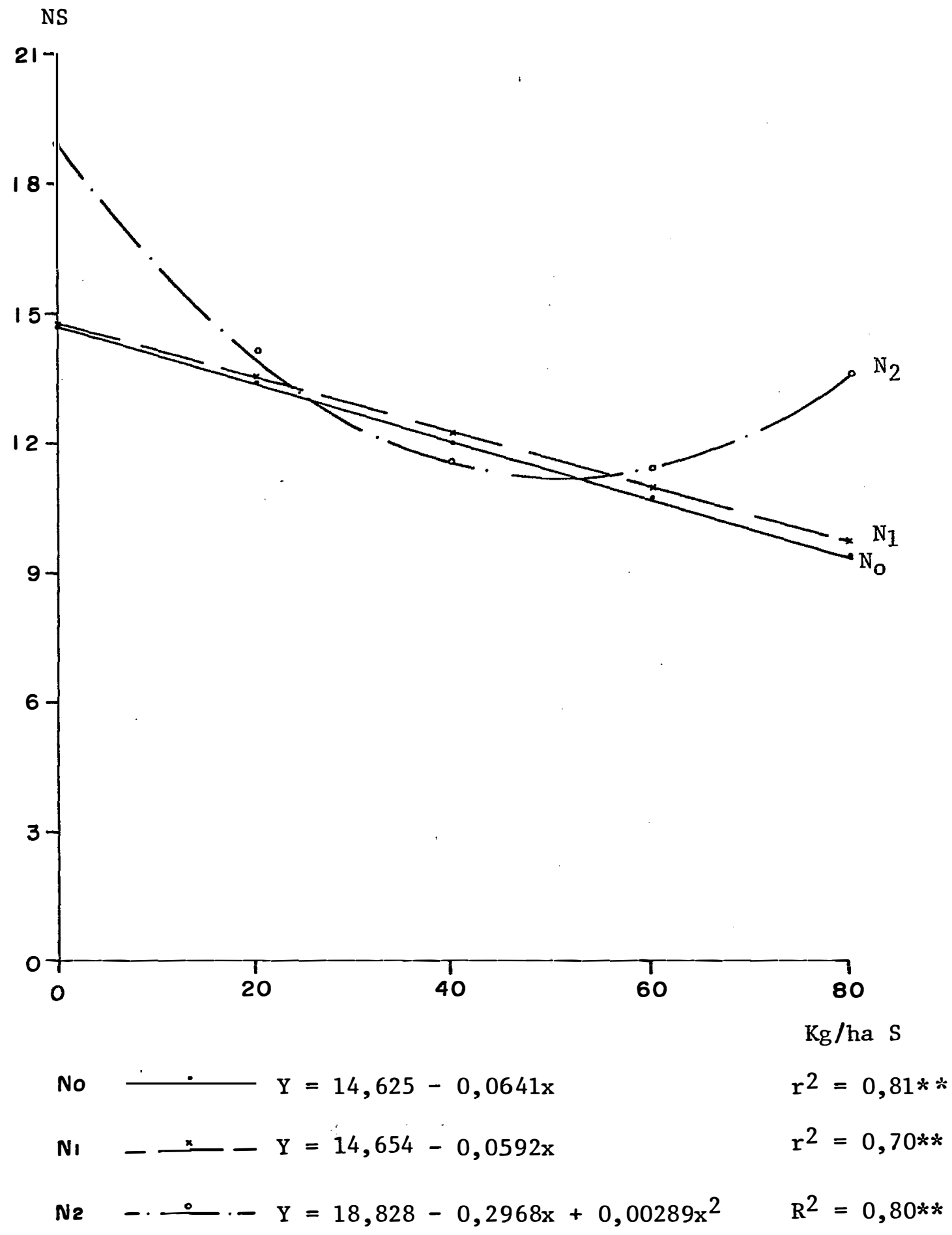

Figura 11 - Efeito de doses de $\mathrm{S}$ na relação $\mathrm{N} / \mathrm{S}$ da parte aérea em cada nível de $N$ utilizado. 


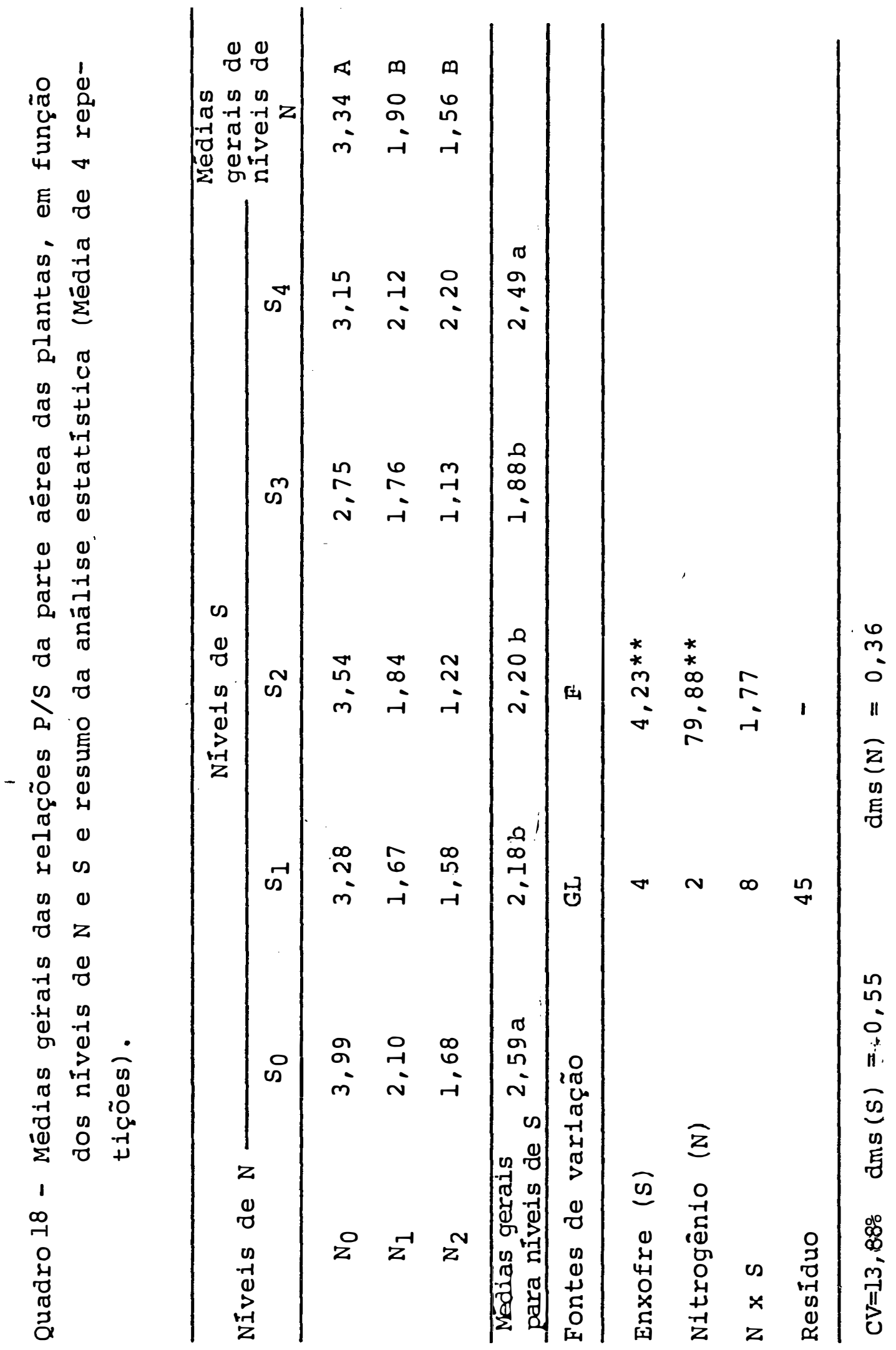




\section{$\mathrm{P} / \mathrm{S}$}

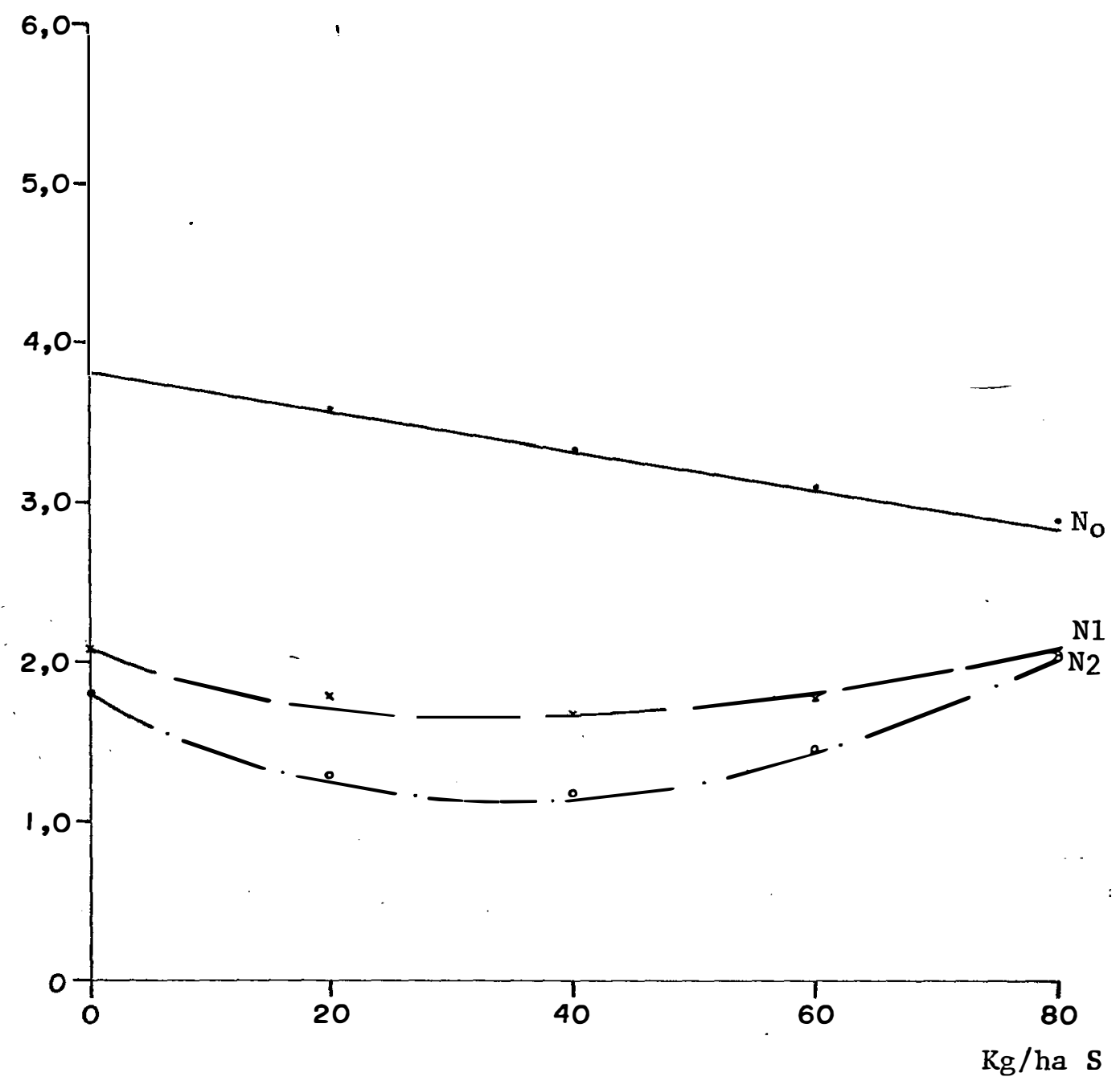

$$
\begin{aligned}
& \text { No }-\mathrm{Y}=3,785-0,0110 \mathrm{x} \quad \mathrm{r}^{2}=0,57 * * \\
& \mathrm{~N}_{1}-\longrightarrow \mathrm{Y}=2,064-0,0181 \mathrm{x}+0,00023 \mathrm{x}^{2} \quad \mathrm{R}^{2}=0,77 * * \\
& \mathrm{~N}_{2}-\cdots+\mathrm{Y}=1,814-0,0344 \mathrm{x}+0,00047 \mathrm{x}^{2} \quad \mathrm{R}^{2}=0,72 * *
\end{aligned}
$$

Figura 12 - Efeito de doses de $S$ na relação $P / S$ da parte aérea em cada nível de $\mathrm{N}$ utilizado. 


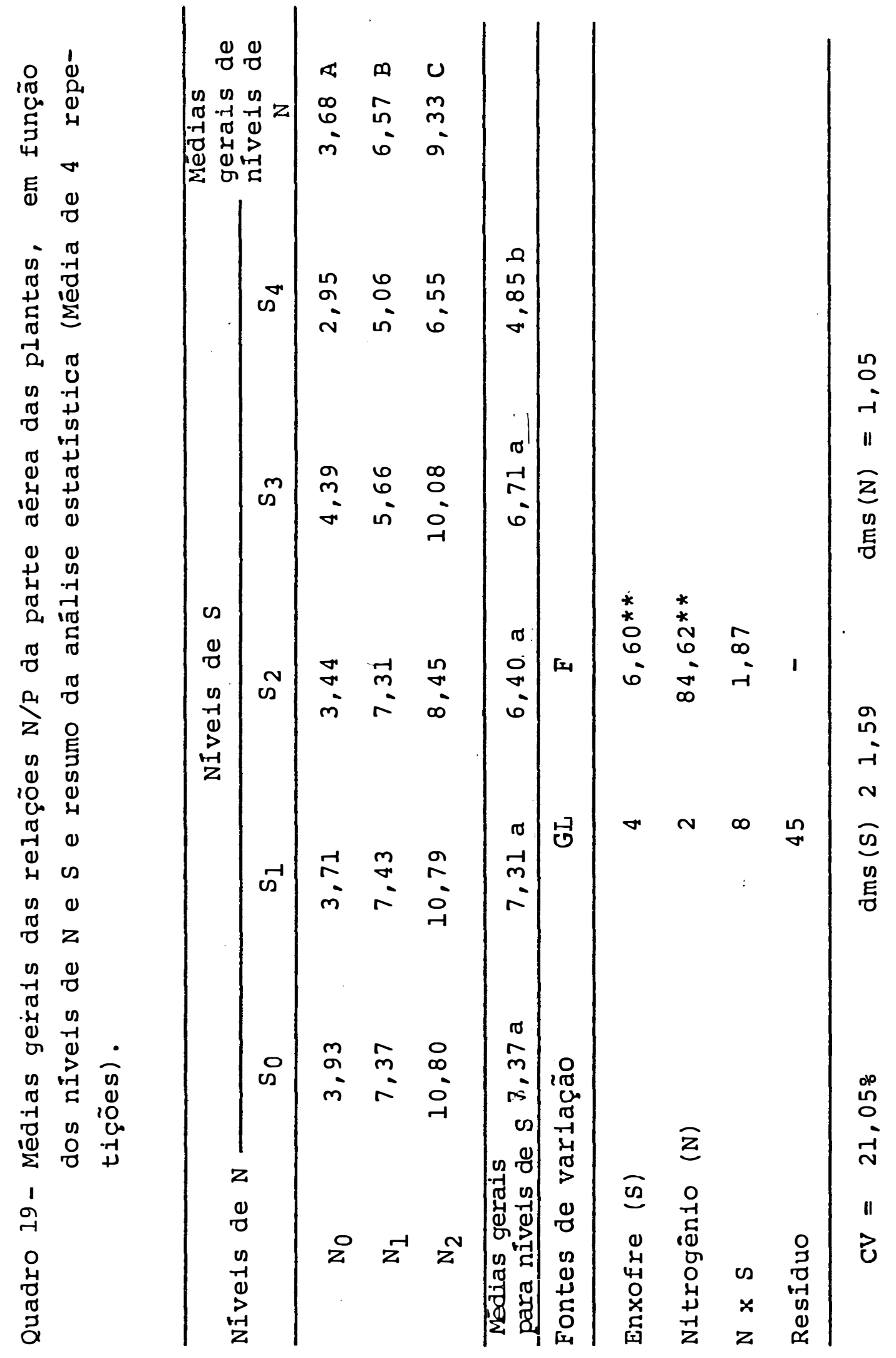



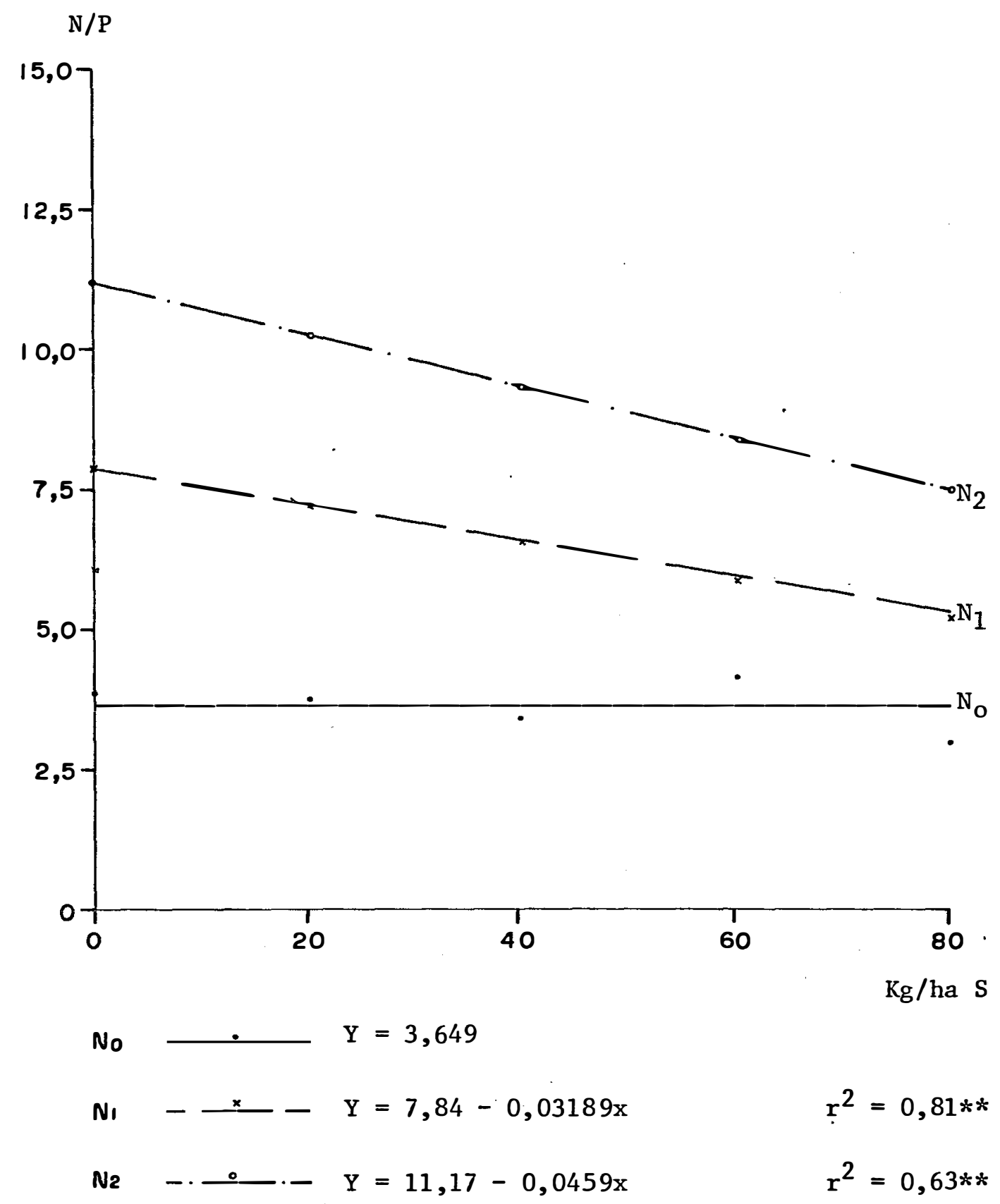

Figura 13 - Efeito de doses de $\mathrm{S}$ na relação N/P da parte aérea em cada nível de $\mathrm{N}$ utilizado. 
doses de 55 a $60 \mathrm{~kg} / \mathrm{ha}$ de $\mathrm{s}$, as quais, permitiram máxima prodū ção de matéria seca as respectivas relações N/S, P/S e N/P variaram de 11,1 a 11,$5 ; 1,3$ a 1,8 e 6,0 a 8,6 .

De todas essas relações a mais conhecida é a N/S, a qual tem sido empregada para avaliar o estado nutricional da forragem quanto ao enxôfre, bem como para avaliar a produção máxima da mesma e para a nutrição adequada de ruminantes (WALKER et alii, 1956). Assim, com relação aos valores encontrados para a relação $\mathrm{N} / \mathrm{S}$, verifica-se que os mesmos estão próximos dos citados por MCNAUGHT e CHRISTOFFELS (1961), isto é, de 11 a 12 para gramineas permitiram produção máxima das forrageiras ou ainda de HAAG et alii(1967) que encontraram relação N/s para o capim colonião de $12 / 1$ aos 84 dias de desenvolvimento, bem como de 10,2/1 em pastagens, conforme citado por SHIRLEY e MARIANTE (1976). SHEARD(1974) também notou que a habilidade da graminea em adquirir $\mathbf{S}$ de uma aplicação superficial de gesso, era função da adubação nitrogenada e que esse incremento pela interação $\mathrm{N} \times \mathrm{S}$, seria compatível ao efeito sinergético da interação $N \times$ P.

\subsection{Efeito dos tratamentos sobre os teores de proteína e.} da digestibilidade da matéria seca

Utilizando-se dos dados obtidos para as concentrações de nitrogênio da parte aérea do capim (Tabela 3 e Qua- 
dro 9), estimaram-se os teores de proteîna $(\mathrm{N} \times 6,25)$, conforme os dados constantes na Tabela 14 e Quadro 20 e Figura 14).

Analisando-se esses dados observa-se um aumento no teor da mesma com o aumento das doses de $\mathrm{N}$ utilizadas, passando de 5,13\% (nível $\mathrm{N}_{0}$ ) para $10,19 \%$ (nível $\mathrm{N}_{2}$ ). Com relação a esses teores, JARDIM et alii (1962) citam que 8\% de proteína bruta na matéria seca é o valor mínimo, para a planta não ser considerada deficiente à nutrição do ruminante.

Já, TESSEMA (1972) obteve para o capim Colonião, valores de $9,5,4,4$ e 4,9\% de proteína bruta, respectivamente, para cortes realizados aos 28,49 e 56 dias de desenvolvimento. Na Figura 14 é apresentado o efeito de doses de $\mathrm{S}$ no teor de proteína da matéria seca da parte aérea, em cada nível de $\mathrm{N}$ utilizado, observando-se que somente no nível $\mathrm{N}_{2}$ houve um efeito quadrático de doses de $\mathrm{S}$, ocasionando um aumento máximo no teor de proteína (cerca de 11,17\%) na dose de $40 \mathrm{~kg} / \mathrm{ha}$ de $\mathrm{s}$.

Com relação à digestibilidade da matéria seca (Tabela 15), observa-se um aumento significativo da mesma com o incremento de doses de $\mathrm{N}$ e/ou $\mathrm{S}$ (Quadro 21). Na Figura 15 é apresentada a variação desse parâmetro dentro de cada nível de N utilizado, em função das doses de S empregadas, verificando-se uma digestibilidade máxima (cerca de 49\%), ao redor de $50 \mathrm{~kg} / \mathrm{ha}$ de $\mathrm{s}$. 
ס

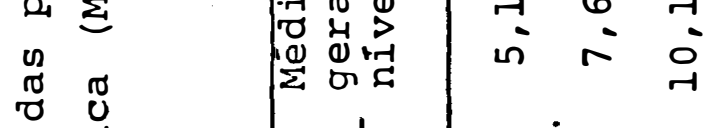

\%

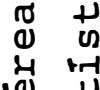

幽 +

$\begin{array}{ll}1 & 0 \\ + & 0\end{array}$

崩

Q

ट

-

E

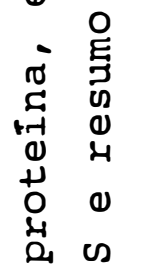

व 0

$z$

先

प्र

$\left|\begin{array}{ccc} & & \\ 0 & 0 & 0 \\ 0 & 0 \\ 0 & 0 & 0 \\ 0 & -7 & -7 \\ -1 & -7 & z \\ 0 & 0 & 0 \\ 0 & 0 & 0 \\ 0 & 0 & 0-1\end{array}\right|$

$\begin{array}{lll}\pi & m & u \\ m & 0 & 0 \\ m & \sim & 0\end{array}$

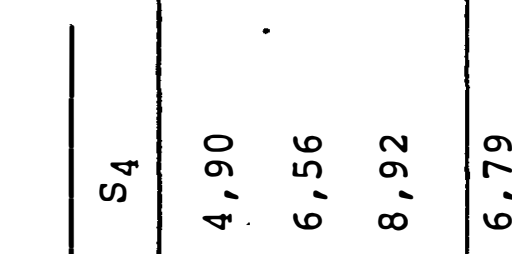

$\mid$

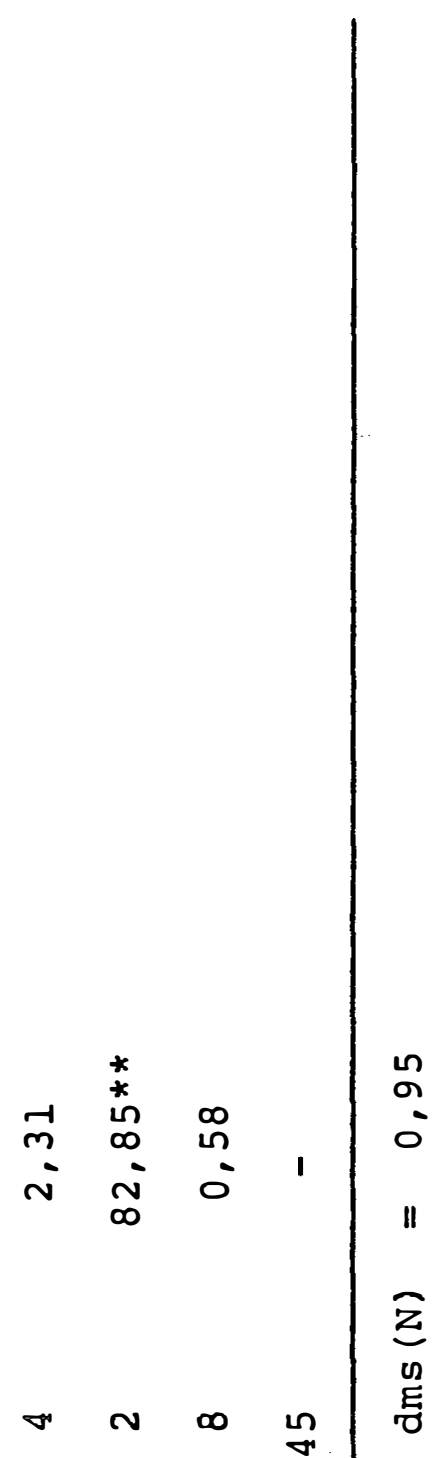

वे

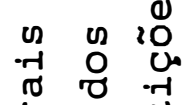

मु 0 गै

סi 2000

- 4 क

岂 E

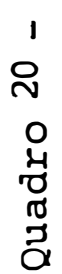

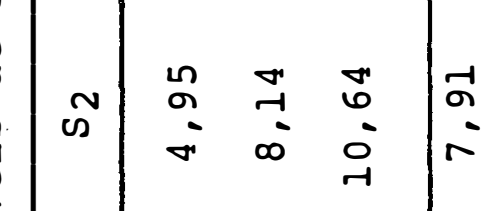

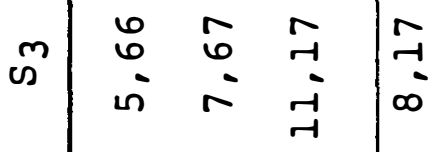

다

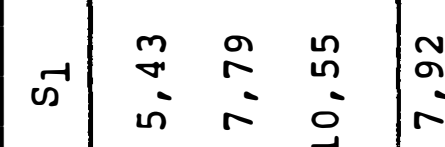

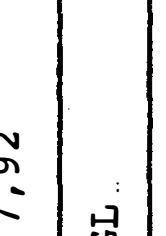

(

$\circ$

N

叒

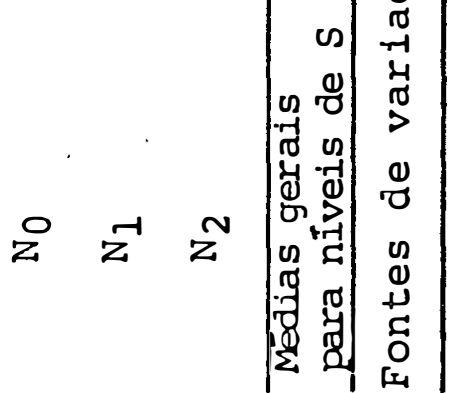

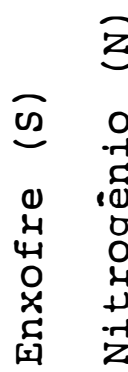

$\stackrel{\substack{10 \\ \sim}}{-1}$

7

$\stackrel{0}{0}$

$n$
-1
0
0
$2-1$
$z$

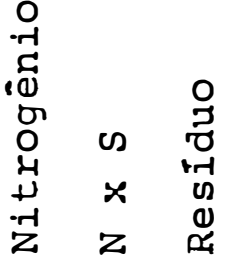

ए 
Proteỉna (\%)

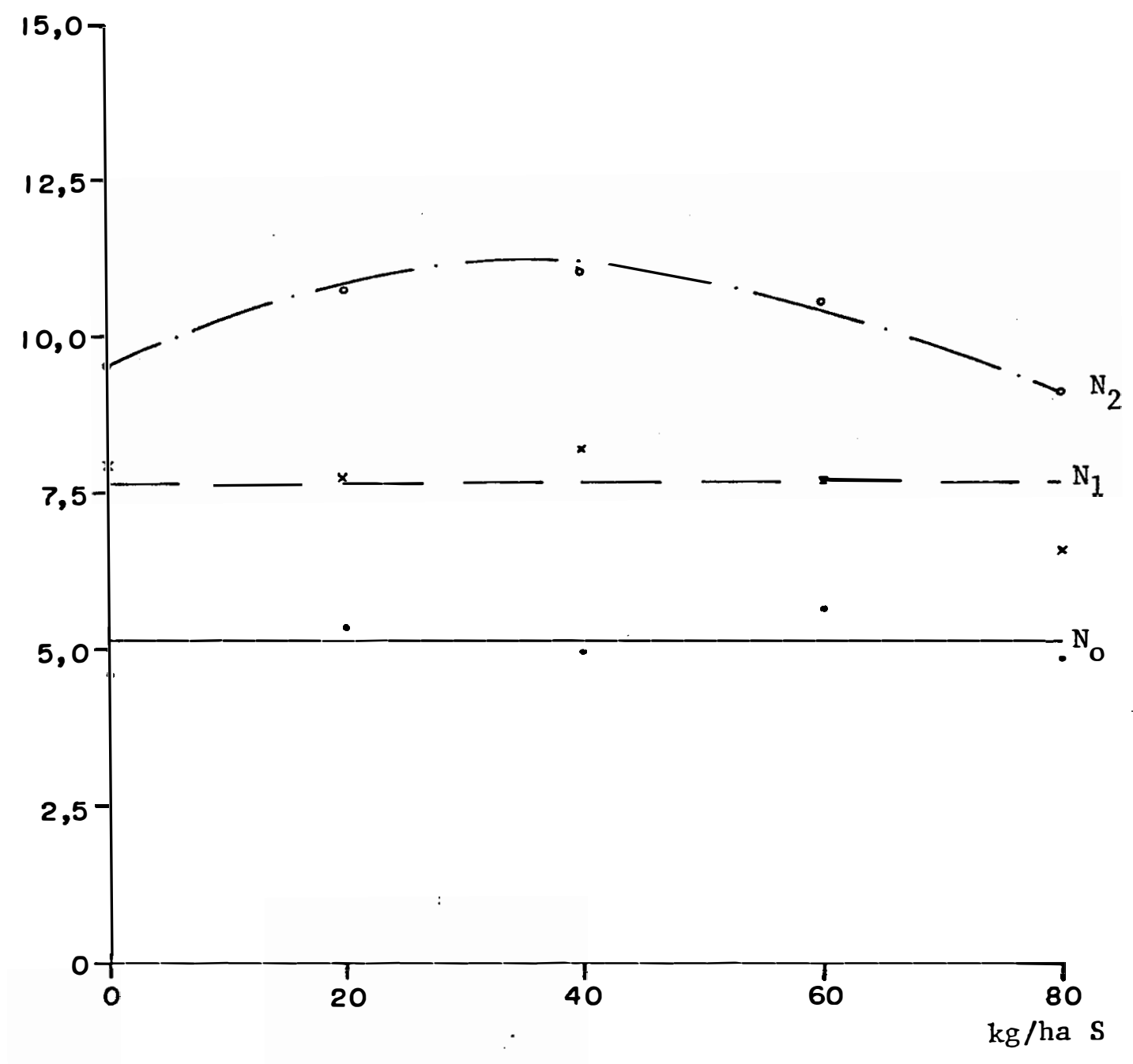

No $\quad \mathrm{Y}=5,133$

$N_{1}-x-Y=7,620$

Ne $-\cdot \frac{\circ}{-} \mathrm{Y}=9,518+0,0794 \mathrm{x}-0,00104 \mathrm{x}^{2} \quad \mathrm{R}^{2}=0,79 \%$

Figura 14 - Efeito de doses de $S$ no teor de proteína da matéria seca da parte aérea, em cada nível de $\mathrm{N}$ utilizado. 


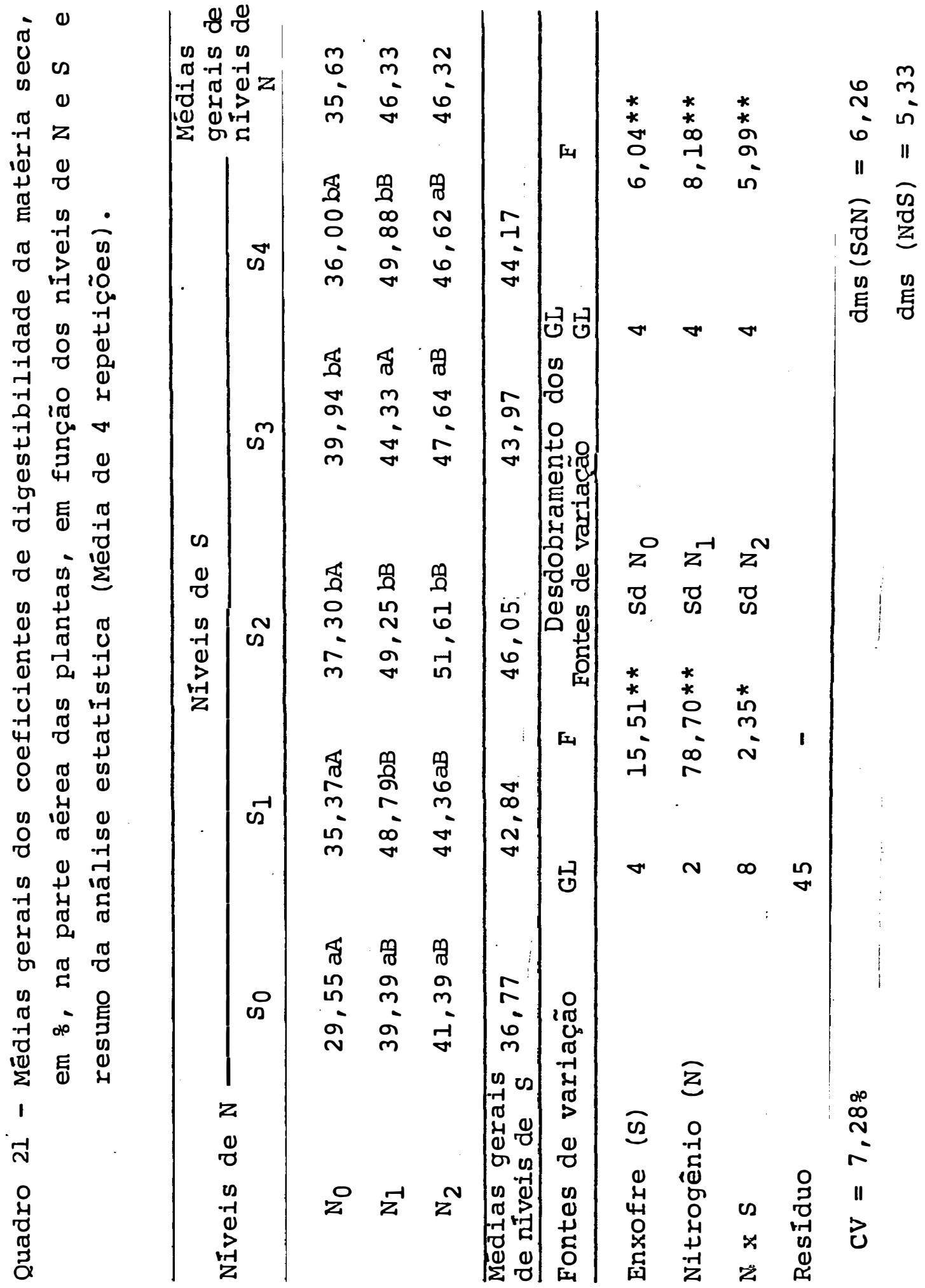


Digestibilidade

(\%)

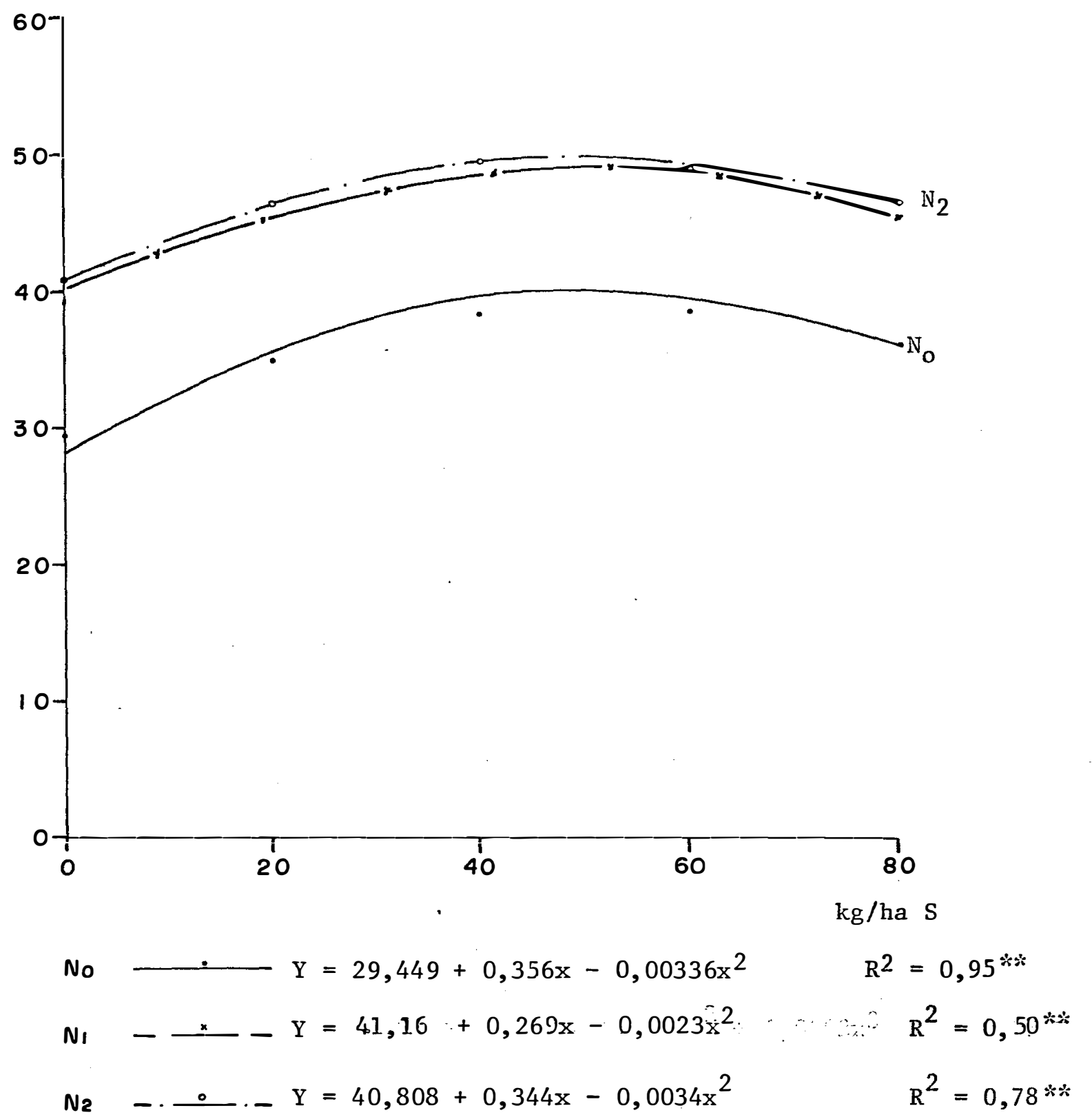

Figura 15 - Efeito de doses de S na digestibilidade "in vitro" da matéria seca da parte aérea em cada nível de $\mathrm{N}$ utilizado. 
Com relação à amplitude de variação desses valo res (29,55 para $\mathrm{NOS}_{0}$ a 49,88 $\mathrm{N}_{1} \mathrm{~S}_{4}$ ), ASARE (1974) encontrou para o colonião uma variação nos coeficientes de digestibilidade da matéria seca "in vitro" de 37,4 e $51,6 \%$, enquanto BUTTERWORTH (1967) encontrou o valor de 47,9\% aos 63 dias de desen volvimento do colonião. BARTON et alii (1971) concluiram que aumentando-se a porcentagem de enxôfre total na matéria seca da forragem, via adubação, promovia-se um aumento linear no coeficiente de digestibilidade "in vitro" da celulose. 


\section{CONCLUSÕES}

Nas condições do experimento; os dados obtidos permitem concluir que:

a - Houve efeito linear do $\mathrm{N}$ e efeito quadrático do S bem como uma interação positiva da aplicação desse nutrientes na produção de matéria seca de capim colonião.: As doses de $S$, na forma de gesso, que permitiram máxima produção de matēria seca variaram de 55 a $60 \mathrm{~kg} / \mathrm{ha}$, respectivamente, para as doses de 100 e $200 \mathrm{~kg} / \mathrm{ha}$ de $\mathrm{N}$.

b - As quantidades absorvidas (mg/vaso) de N, S, P e Ca foram afetadas positiva e significativamente pela interação $\mathrm{N} \times \mathrm{S}$.

c - O gesso funcionou como fonte de s e Ca para o capim Colonião. 
d - As relações N/S, P/S e N/P da parte aérea aos 60 dias após a germinação que permitiram māxima produção de matéria seca variaram, respectivamente, de 11,1 a 11,$5 ; 1,3$ a 1,8 e 6,0 a 8,6 .

e - Houve efeito linear da aplicação de nitrogênio nos teores de proteína da parte aérea, sendo que para o nível $\mathrm{N}_{2}(200 \mathrm{~kg} / \mathrm{ha}$ de $\mathrm{N})$ o máximo teor $(11,03 \%)$ foi alcançado pela aplicação aproximada de $40 \mathrm{~kg} / \mathrm{ha}$ de $\mathrm{s}$.

f - A digestibilidade "in vitro" da matéria seca res pondeu à aplicação de $\mathrm{N}$ e $\mathrm{S}$, tendo alcançado valores máximoṣ, estimados em torno de $49 \%$ pela aplicação de $50 \mathrm{~kg} / \mathrm{ha}$ de $\mathrm{S}$ nos dois niveis de $\mathrm{N}$ utilizado. (100 e $200 \mathrm{~kg} / \mathrm{ha})$. 
6. LITERATURA - CITADA

ADAMS, C.A. E R.W. SHEARD. 1966. Alterations in the nitrogen metabolism of Medicago sativa and Dactylis glomerata as influenced by potassium and sulphur nutrition. Can. J. Plant Sci. $46: 671-680$.

ADAMS, W.Z. 1967. A comparison of coastal and common Bermuda grasses (Cynodon dactyzon) in the Piedmont region II. Effect of fertilization on crimsonclover (Trifolium encarnatum) on nitrogen, phosphorus and potassium content of the forage. Agronomy, Madison 59:

ALLAWAY, W.H. E J.F. THOMPSON. 1966. Sulphur in the nutrition of plants and animals. Soil Sci, 101(4): $220-247$ 
ASARE, E.O. 1974. Dry matter, yield, chemical composition and nutritive value of buffel grass alone and in mixture with other tropical grasses and legumes. In: Int I. Grass 2 . Congr. Utilization, Moscow, vol. l, p.53-57.

ASHENDEN, T.W. 1978. Growth reduction in cocksfoot Dactylis glomerata L.) as a result fo $\mathrm{SO}_{2}$ pollution. Environmental Polzution, 15:161-166.

ATKINSON, W.T.; WALKER e R.G. WEIR. 1965. The phosphorus and sulphur needs of pastures in New South Wales. Anais do IX Congr. Int. Pastagens, São Paulo, Vol. I,.p.655-663.

AULAKH, M.S. E N.S. PASRICHA. 1978. Interaction of feet of sullphur and phosphorus on growth and nutrient content of Moong (Phaseolus aureus). Plant and Soil, 47,341-346.

AWAN, A.B. 1965. Relation between phosphorus and micronutrients in plants. Proc. Soil Sci. Soc. Amer., Madison, $27(4): 389-391$.

BARKER, A.V. 1979. Nutritional factors in photosynthesis of higher plants. Journal of Plant Nutrition, I(3):309-342.

BARKER, A.V. E R.J. VOLK. 1964. Determination of ammonium, amide, amino and nitrate-nitrogen in plant extracts by a modified Kjeldahl method. Anal. Chem. 36:439-445. 
BARTON, J.S.; L.S. BULL; e R.W. HEMKEN. 1971. Effects of various levels of sulphur upon cellulose digestion in purified diets and lignocellulose digestion of corn fodder pellets in vitro. J. An. Sci., Albany, 33:682-685.

BEGG, J.N.B. e W.S. CLOUGH. 1973. Depression yield in ryegrass exposed to sulphur dioxide. Nature, 241:47-49.

BOTTRILL, D.E.;.J.V. POSSIGHAM e P.E. KRIEDEMANN. 1970. The effect of nutrient deficiencies on photosynthesis and respiration in spinach. Plant and Soil, 32:424-438.

BRAY, A.C. e A.R. TILL. 1975. Metabolism of sulphur in the gastro-intestinal tract. In: McDonald, I.W. e A.C.I. Warner (ed.). Digestion and Metabolism in the Ruminant. Proceedings of IV Intl. Symp. on Ruminat Physiology, Sidneý, Australia, The University of New England Publishing Unit. 602p.

BURNS, R.H.; A. JOHNSTON; J.W. HAMILTON; J. MCCOLLOCH; W.E. DUNCAN e H.G. FISK. 1964. Minerals in domestic wools. J. Animal Sci. 23:5-12.

BUTTERWORTH, M.H. 1967. The digestibility of tropical grasses. In: Nutr. Abstr. Review. Abeerden 137:349 (Review article). CARO-COSTA, R.J.; J.VICENTE CHANDLER e J. FIGARELLA. 1960. The yields and composition of five grasses growing in the humid mountains of Puerto Rico as affected by nitrogen fertilization, season and harvest procedure. J. Agric. Univ. Puerto Rico, 44:107-111. 
CASAGRANDE, J.C. e O.C. DE SOUZA. 1982. Efeito de níveis de enxofre sobre quatro gramineas forrageiras tropicais. Pesq. Agrop. Bras. Brasilia, $17(1): 21-25$.

CATANI, R.A. e A.O. JACINTHO. 1974. Avaliação da fertilidade do solo - Métodos de Anālise. Piracicaba. LIVROCE RES Ltda. 57p.

CIAT (CENTRO INTERNACIONAL DE AGRIOUITURA TROPICAL) - 1978. Beef production program. Ann. Rep. CALI, 1977. 114p.

CIAT (CFNTRO INTERNACIONAL DE AGRIOULTURA TROPICAL) - 1979. Progra ma de ganado de carne. Informe Anual, 1978. Cali, 8lp.

CHAO, T.T.; M.E. HAYWARD E S.C. FANG. 1962. Movement of $s^{35}$ tagged sulphate through soil colunns. soil sci. sco. Amer. Proc. 26:27-32.

CLATWORTHY, J.N. 1967. The response of giant Rhodes grass (Chloris gayana - Kunth) to heavy dressing of nitrogen fertilizer. Herb. Abstr., London, 37:1713-1716.

COLEMAN, R. 1966. The importance of sulfur as a plant nutrient in world crop production. Soil Sci., 101:230239.

COOPER, J.P. e N.M. TAINTON. 1968. Light and temperature requirements for the growth of tropical and temperate grasses. Herbage Abstracts., Aberystwith, 38:167-173. 
CRAMPTON, E.W. e L.E. HARRIS. 1969. United States-Canadian tables of feed composition. NRC publ. 1684. National Academic of Sciences. Washington, D.C.

DAS, G. e V.C. RUNECKLES. 1975. Bio-sulphite induced inactivation of growth and chlorophyll formation in Chlorelza pyrenoidosa. Journal of Exp. Botany, 26:705712 .

DEINUM, B.; A.J.M. VAN ESS e P.J. VAN SOEST. 1968. Climate, nitrogen and grass. II. The influence of light intensity, temperature and nitrogen on "in vivo" digestibility of grass and the prediction of these effects from some chemical procedures. Netherlands J.Agr. Sci., Wageningen, $16(3): 217-225$.

DIJKSHOORN, W. e S.L. VAN WIJK. 1967. The sulphur requirements of plants as evidenced by the sulphur-nitrogen ratio in the organic matter. A review of published data. Plant and soir, 26:129-157.

EATON, F.M. 1966. In: Diagnosis criteria for plant and soils. Chapman, H.D. (ed.). Univ. of California, Div. of Agric. Sci., Berckeley, p.444-475.

FAGERIA, N.K. e H. SINGH. 1982. Response of wheat to soil application of nitrogen and sulphur. Pesq. Agrop. Bras. $17(8): 1121-1126$. 
FARINA, M.P.W.; G.W. GROSS e P. CHANNON. 1972. The influence of sulphur on the yield of a grass-clover pasture fertilized with different sources of phosphorus Fert. Soc. of South Africa J. 1:1-13.

FOX, R.L.; H.M. ATESALP; D.H. CAMPBELL e H.F. RHOADES. 1964. Factors influencing the availability of sulphur fertilizer to alfalfa and corn. Soil Sci. Soc. Amer. Proc. 28:406408 .

FRENCH, H. e L.M. CHAPARRO. 1960. Contribución al estudio de la composiciōn química de los pastos en Venezuela durante la estación seca. Agronomia Tropical, Maracay, $10(2): 57-69$.

FRIEDRICH, J.W. E L.E. SCHRADER. 1978. Sulphur deprivation and nitrogen metabolism in maize seedlings. Plant PhysioZogy, $61: 900-903$

FUGIWARA, A. e R.K.TORRI. 1961. Physiology of sulphatation in higher plants. I. Effect of sulphur deficiency on metabolism of higher plants. Tohoku J. Agr. Res, Tohoku, $12: 277-289$.

GOMES, F.P., 1973. Curso de Estatistica Experimental. 5a. ed. São Paulo, Nobel. 530p. 
GOMIDE, J.A.; C.H. NOLLER; G.O. MOTT; J.H. CONRAD e D.L. HILL. 1969. Mineral composition of six tropical grasses as influenced by plant and nitrogen fertilization. Agron. J., Madison, 61:120-128.

GOMIDE, J.A.; J.A. OBEID e J.F. TEIXEIRA NETO. 1979. Produtividade e valor nutritivo do capim colonião (Panicum maximum Jacq.). Rev. Soc. Bras. Zoot., Viçosa, 8(2):198225.

GREGG, P.E.H. e K.M. GOH. 1978. Field studies with radioactive sulphur labelled gypsum fertilizer. I. Soil factors affecting the movement of fertilizer sulphur. N.Z.J. Agric. Res. 21:593-601.

GUIMARÃES, P.T.G.; J.G. FERREIRA; J.G. de CARVALHO e S.L. LOPES. 1980. Adubação de pastagens. Inf. Agrop. Belo Horizonte, 6(70):34-37.

HAAG, H.P.; M.L.V. BOSE e R.G. ANDRADE. 1967. Absorção dos macronutrientes pelos capins Colonião, Gordura, Jaraguá, Napier e Pangola. Anais da E.S.A. "Luiz de Queiroz", Piracicaba, 24:177-188.

HAGGAR, R.J. e M.B. AHMED. 1970. Seasonal production of Andropogon gayanus. II. Seasonal changes in digestibility and feed intake. J. Agric. Sci., Cambridge,75(3):369-373. 
HALSE, N.J.; E.A.N. GREENWOOD; P. LAPINS E C.A.P. BOUNDRY. 1969. An analysis of nitrogen deficiency on the growth and yield of western Australia wheat crop. Austr. $J$. Agr. Res, Melbourne, 20:987-989.

HANSON, E.A.; B.S. BARRIEN e J.G. WOOD. 194l. Relationship etween protein-nitrogen, protein-sulphur and chlorophyll in leaves of Sudan Grass. Austr. J.Exp. Biol. 19:231-234.

HOAGLAND, D.R. e D.I. ARNON. 1950. The water culture method for growing plants without soil. Bekerley, California, Agricultural Experiment Station (Circular 347).

HOUVINEN, J.A. e B.F. GUSTAFFSON. 1967. Inorganic sulphate and sulphite as sulphur donor in the biosynthesis of sulphur aminoacids in germ free and conventional rats. Biochem. Biophys. Acta, 136:441-447.

JARDIM, W.R.; A.M. PEIXOTO e C.L. MORAES. 1962. ObservaçÕes sobre deficiências minerais na nutrição de bovinos na região do Brasil Central. E.S.A. "Luiz de Queiroz", Piracicaba, Bol. Tecn. Cient. no 13.

JOHANSON, O. 1959. On sulphur problems in Swedish Agricultural. Ann. $R$. Colz. Sweden, Stockholm, 25:57-61.

JOHNSON, W.L.; A.L. ORDOVEZA; W.A. HARDINSON E L.S. CASTILHO: 1967 The nutritive value of Panicum maximum (guineagrass).II. Digestibility by cattle and water bufaloes related to season and herbage growth stage. J.Agric. Sci., Cambridge, 69:161-166. 
JONES, M.B. 1964. Effect of applied sulphur on yield and sulphur uptake of various California dryland pasture species. Agron. J., Madison, 56:235-237.

JONES, M.B. e J.L. QUAGLIATO. 1970. Resposta de quatro leguminosas tropicais e da alfafa a vários níveis de enxofre. Pesq. Agrop. Bras., 5:359-363.

JONES, M.B.; J.L. QUAGLIATO e L.M.N. FREITAS. 1970. Resposta de alfafa e algumas leguminosas tropicais a aplicações de nutrientes minerais em trēs solos de campo cerrado. Pesq. Agrop. Bras. 5:209-214.

JONES, M.B. E J.E. RUCKMAN. 1972. Effects of $S$ and $P$ in nutritive value of clover. Sulphur Inst. J. 8:2-5.

JORDAN, H.V. e L.E. ESMINGER. 1958. The role of sulphur in soil fertility. Advances in Agronomy, $x: 407-434$.

KAYONGO-MALE, H.; J.W. THOMAS; D.E. ULREY; R.J. DEANS e J.A. ARROYO-AGUILU. 1976. Chemical composition and digestibility of tropical grasses. $J$. Agric. Univ. Puerto ico, San Juan, 60:186-

KENNEDY, P.M. 1974. Utilization and excretion of sulphur in cattle fed on tropical roughages. Austr. J.. Agr. Res. Melbourne, 25:1015-1019。

KRUGG,F.J.; H. BERGAMIN FILHO; E.A.G. ZAGATTO e S.S. JORGENSEN. 1977. Rapid determination of sulphate in natural waters and plant digest by continuous flow infection turbidimetry. Analyst, 102:503-508. 
LANGER, R.H.M. 1963. Tillering in herbage grasses. A review. Herb. Abstr. Aberystwyth, 33:141-148.

LANGER, R.H.M. e F.K.Y. LIEW. 1973. Effect of varying nitrogen supply at different stages of the reproductive phase on spekelet and grain production and on grain nitrogen of wheat. Austr. J.Agr. Res. Melbourne, 24: $647-650$

LEITE, G.G. e W. COUTO. 1982. Adubação para estabelecimento e manutenção de pastagens nos cerrados. In: VILELA, H.; J.A.V. PIRES; J.R.A. SILVESTRE e W.S. NUNES (eds.). Anais do 10 Encontro sobre Formacão e Manejo de Pastagens em Àreas de Cerrado. EMATER, M.G., Uberlândia, p. 47-74.

LOOSLI, J.K. 1952. Meeting the sulphur requirements of ruminants. Feed Age, $44: 45-48$.

MACY, I.G.; J. HARRIET E R.E. SLOAM. 1953. The composition of milks. A compilations of the comparative composition and properties of human, cow and goat milk, colustrum and transitional milk. NRC publication, National Academic of Sciences. Washington, D.C. 29p.

MALAVOLTA, E., 1977. Nutrição e Adubação de Forrageiras. Curso de Pós-Graduação em Produção Vegetal. Disciplina de Nutrição e Adubação de Plantas Cultivadas. F.C.A.V. Jaboticabal. 15p (mimeografado). 
MALAVOLTA, E. 1978. Nutrição mineral de plantas e tecnologia de fertilizantes. Princípios, problemas e perspectivas. In: Curso de Atualização em Fertilidade do Solo. Jaboticabal, SP. Faculdade de Ciēncias Agrārias e Veterinārias-UNESP. 2lp. (mimeografado).

MARTEL, Y.A. E J. ZIZKA. 1977. Yield and quality of alfalfa as influenced by addition of $\mathrm{S}$ and $\mathrm{K}$ fertilization under greenhouse use conditions. Agron. J. Madison, 69:531535.

MARTIN, W.E. E T.W. WALKER, 1966. Sulphur requirements and fertilization of pasture and forage crops. Soil Sci., $101(4): 248-257$

MASUDA, Y. 1977. Digestibility and structural components of some tropical grasses. Japanese Agr. Res., Yatobe, $11(1): 60-68$.

MATHENY, T.A. E P.G. HUNT. 1981. Effects of irrigation and sulphur application on soybeans grown on a Norfolk loamy sand. Commun. Soil Sci. Plant Anal. 12(2):147-189.

MAYNARD, D.N. 1979. Nutritional disorders of vegetable crops. A Review. Journal of Plant Nutrition, 1(1):1-23.

MCCANCE, R.A. e E.M. WIDDOWSON. 1940. The chemical composition of food. Privy Council Med. R es., His Majesty's Stationary office, London. 190p. 
MCCLUNG, A.C. e L.R. QUINN. 1959. Resposta da grama batatais (Paspalum notatum) às aplicaçọes de enxofre e fósforo. New York, IBEC Research Inst. Bol. 18, 16p.

MCCLUNG, A.C.; L.M.M. FREITAS e W.L. LOTT. 1959. Estudos sobre o enxofre em solos de São Paulo. New York, IBEC Research Institute Bull. 17.

MCCLUNG, A.C. e L.M.N. FREITAS. 1969. Sulphur deficiency in soils from brasilians fields. Ecology, 40(2):315-317.

MCNAUGHT, K.N. e P.J.E. CHRISTOFFELS. 1961. Effect of sulphur deficiency on sulphur and nitrogen levels in pastures and lucerne. New Zealand J. Agr. Res, 4:177-185.

MENESES, J.B.; A.B. FERREIRA; R.I.J. HIPPOLITO e G.A. DUSI. 1973. Contribuição ao estudo da digestibilidade aparente dos fenos de capim Pangola (Digitaria decumbens), Angola (Brachiaria mutica) e Colonião (Panicum maximum) em diferentes estágios de desenvolvimento. Agronomia, Rio de Janeiro, 31:51-59.

MILCHUNAS, D.G.; W.K. LAUENROTH; J.L. DADD e F.J. MCNARY. 1981. Effects of $\mathrm{SO}_{2}$ exposure with nitrogen and sulphur fertilization on the growth of Agropyron smithii. J. of Applied Ecology, 18:291-302.

MILLER, D.S. e G. DONOSCO. 1963. Relation between the sulphur/nitrogen ratio and the protein value of diets. J. Sci. Food Agr. 14:345-349. 
MINSON, J.J. e M.N. MCLEOD. 1970. The digestibility of temperate and tropical grasses. In: Proc. of XI IntZ. Grassi. Congr., Surfers. Paradise, Australia p.719-723. MINSON, D.J. 1971. The digestibility and voluntary intake of six varieties of Panicum. Austr. Exp. Agr. An. Husb. Rockhampton, $2: 17-26$.

MITCHELL, H.H. e F.J. MCCLURE. 1937. Mineral nutrition of farm animals. National Research Bull. 99 Council. National Academic of Science, Washington, DC. $37 \mathrm{p}$.

MnKENI, P.N.S. e A.F. MACKENZIE. 1981. Effects of sulphur and phosphorus fertilization on the yield and quality of barley. (Hordeum vuigare, L.) in three southwestern Quebec soils. Can. J. Soiz Sci, 61:351-359.

MOTT, G.O.; L.R.C. QUINN e W.A. BISCHOFF. 1965. Supplemental feeding of steers and nitrogen fertilization on their effect upon beef production from guinea grass pasture. Anais IX Congr. Inst. Pastagens, são Paulo, vol. II, $981-988$

MURRIETA, L.A. 1978. Efeitos da adição de uma mistura de ácido fórmico e formol na ensilagem de capim colonião. Piracicaba, ESALQ-USP, Tese de Mestrado, 196p. 
NRC. 1976. Nutrients requirements of domestics animals. IV. Nutrients requirements of beef cattle. National Research Council. National Academic of Sciences. Washington, DC. $56 \mathrm{p}$.

NELLER, J.R. 1959. Extractable sulphate-sulphur in soils of Florida in relation to amount of clay in the profile. Soil Sci. Soc. Amer. Proc., 23:346-348.

OBULAJO, F.D.; P.J. VAN SOEST e V.A. OYENUGA. 1974. Comparison and digestibility of four tropical grasses grown in Nigeria. Journal of Animal Science, Albany, 38(1): $149-153$.

OLSEN, F.J. 1974. Effects of nitrogen fertilizer on yield protein content of Brachiaria mutica (Forsk) Stapf, Cynodon dactylon (L) Pers and Setaria splendida, Stapf in Uganda. Trop. Agr. Trinidad, 51:523-528.

PEDREIRA，J.V.S.; J.C. WERNER; G.L. ROCHA e B.CINTRA. 1965. Etudos preliminares de introdução de plantas forrageiras no sul do Estado de são Paulo. Anäis do IX Congr. Intr. Past. São Paulo. Vol. II. 1537-1541.

PIRSON, A. 1955. Functional aspects in mineral nutrition in green plants. Ann. Rev. Plant Physiol., 6:71-114. PUMPHREY, F.V. A D.P. MOORE. 1965. Diagnosing sulphur deficiency of alfalfa (Medicago sativa, L.) from plant analysis. Agron. J., Madison, 57:364. 
QUINN, L.R.; G.O. MOTT e W.A. BISCHOFF. 1961. Fertilização de pastos de capim colonião e produção de carne com novilhos zebu. New York, IBEC Research Inst. Bul. 4. 40p.

QUINN, L.R.C.; G.O. MOTT; W.A. BISCHOFF e M.B. JONES. 1965. Beef production of six tropical grasses in Central Brasil. Anais IX congr. Inst. Pastagens, São Paulo, VOLII. 1015-1020.

RANZANI, G. 1971. Solos do Cerrado no Brasil. In: FERRI, M.G. (ed.) III Simpósio sobre o Cerrado. (Edgard Blucher e EDUSP. São Paulo, 239 p.

REHM, G.W. e A.C. CALDWELL. 1970. Sulphur uptake by corn as influenced bu ammonium and nitrate nitrogen. Soir sci. Soc. Amer. Proc. 34:327-329.

REISENAUER, H.M. e A.D. DICKSON. 1961. Effects of nitrogen and sulphur fertilization on yield and malting quality of barley. Agron. J., Madison, 53:192-195.

RENDIG, V.V. e W.C. WEIR. 1957. Evaluation by lamb feeding test of alfalfa bay grown on a low sulphur soil. J. Anim. Sci. 16:451-461.

RENDIG, V.V.; C.O. OPUTA e E.A. MCLOMB。 1976. Effects of sulphur deficiency on non protein nitrogen soluble sugars and N/S ratio in young corn (2ea mays, L.) plants. plant and soir, 44:423-437. 
RENDIG, V.V. e F.AMPARANO. 1980. Nutreint deficiency diagnosis of corn (Zea mays L.) plants form yield and composition responses to additions of $\mathrm{N}$ and $\mathrm{S}$. Commun. in Soir Sci. and Plant Analysis, 11(12):1181-1193.

ROMANO GALLO, J.; R. HIROCE; O.C. BATTAGLIA; P.R. FURLANI; A.M.C. FURLANI; H.B. DE MATTOS; J.J. SARTINIE e M.P. FONSECA. 1974. Composição quỉmica inorgânica de forrageiras do Estado de São Paulo. Boletim Ind. Animal, são Paulo, 31(1):115-159.

RUSSEL, E.W. 1961. Soil conditions and plant growth. 9a. ed. Longmans, Greenand Co. , Inc. New York. 317p.

SANCHES, P.A. 1976. Properties and management of soils in the tropics. Raleigh, John Wiley \& Sons, Inc., 618p.

SARRUGE, J.R. e H.P. HAAG. 1974. Anālises quỉmicas em plantas. E.S.A. "Luiz de Queiroz", Piracicaba- SP. 57p. (mimeografado) .

SHEARD, R.W. 1974. Nitrogen enhancement of surface applied fertilizer phosphorus uptake by forage species. Can $J$. Soil Sci. 54:89-104.

SHEARD, R.W.; R.H. JACKMAN and G.W. BUTTLER. 1978. Utilization by white clover and ryegrass of sulphur from $\mathrm{s}^{35}$ labelled gypsum. Commun. Soil Sci. Plant Analysis, 9: 935-954 . 
SHEARD, R.W. 1980. Initial and residual utilization by alfalfa and brome-grass of suphur from s5 $^{35}$ labelled gypsum. Commun. in Soil and Plant Analysis, 11(6): 605-619.

SHIRLEY, R.L. e A. MARIANTE. 1976. Enxofre na nutrição de ruminantes. In Simpósio Latino-Americano sobre Pesquisa em Nutrigão Minral de $R$ uminantes em Pastagens. Belo Horizonte-MG, UFMG, UFV, ESAL, EPAMIG, USAID. p.130.

SPIERTZ, J.H.J. E M. VAN DER HAAR. 1978. Differences in grain growth crop.photosynthesis and distribution of assimilates between semi-dwarf and standard cultivars of winter wheat. Netherlands J. AGr. Sci. Wageningen, $26: 233-237$.

STEWART, B.A. e C.J. WHITFIELD. 1966. Effect of crop residue, soil temperature and sulphur on the growth of winter wheat. Agron. J., Madison, 58: 23 .

STEWART, B.A.; L.K. PORTER e F.G. VIETS JR. 1966. Effect of sulphur content of straws on rates of decomposition and plant growth. Soiz Sci. Soc. Am. Proc. 30:355-358.

STEWART, B.A. E I.K. PORTER. 1969. Nitrogen-sulphur relationships in wheat (Titricum aestivum L.) corn ( 2 ea mays, L.) and beans (Phaseolus vulgaris, I.). Agron. J. Madison, $61: 267-271$. 
SUGIMOTO, Y. e I. NIKKI. 1977. Studies on the response of pasture grasses to nitrogen fertilization. 2 . Effects of $\mathrm{N}$ on RGR, NAR, LAR and RLGR of save subtropical grass seedlings. Journal of Japanese Soc. of GrassZ. Sci., Myakaki, 23()$: 114$ apud Herb. Abstr. Aberystwyth $48(8)$ : 333 ref. 2883-2978.

TESSEMA, R. 1972. Nutritional value of some tropical grass species compared to save temperate grass species. Cornell University, Ithaca, Ph.D. Thesis, 479p.

THOMAS, W. 1959. Effects of applied nitrogen and sulphur on the yield and protein content of corn. Agron. J., Madison, $\quad 51: 572-573$.

THOMPSON, J.F. 1967. Sulphur metabolism in plants. Annual Review of Plant Physiology, 18:59-84.

TILLEY, J.M.A. e R.A. TERRY, 1963. A two-stage technique for the "in vitro" digestion of forrage crops. J. British Grassl. Soc. $18: 104-111$.

VELLOSO, L.; M. PROCKNOR e W.J.P.S. STRAZZACAPPA. 1978. Estimativa de produção forrageira e valor nutritivo de um pasto de capim colonião (Panicum maximum Jacq.) fase I. Período de verão. In: Anais da XV ? eunião Anual da SocBras. Zootecnia, Belēm, p.302. 
VICENTE-CHANDLER, J.; S. SILVA e J. FIGARELLA. 1959. The effects of nitrogen fertilization and frequency of cutting on the yield and composition of Napier grass in Puerto Rico. J. Agr. Univ. Puerto Rico, 43:215-219.

VILELA, H. 1977. Manejo de Pastagens em Cerrado. In: Anais IV Simpósio sobre Manejo de Pastagem. ESALQ-USP. Piracicaba, 312p.

VITTI, G.C. 1980. Macronutrientes secundārios - situação, perspectivas e sugestões. Seminārio apresentado à Disciplina "Seminários" do CPG em Solos e Nutrição de Plantas. E.S.A. "Luiz de Queiroz", 37p (mimeografado).

WALKER, T.W. 1955. Sulphur responses on pastures in Australia and New Zealand. Soils fert. 18:181-187.

WALKER, T.W.; A.F.R. ADAMS e H.D. ORCHISTON. 1956. Effect of level of calcium sulphate on yield and composition of a grass and clover pasture. Plant and Soil, 7:290-300.

WELCH, A.V.; A. WALLACE e R. MUELLER. 1954. Influence of factorially combined levels of cations and nitrate ions absorbed on exchange resins on the nutrient absorption by plants. Soils Sci. Soc. Amer. Proc. 18: $137-140$.

WENDT, W.B. 1970. Responses of pasture species in eastern Uganda to phosphorus, sulphur and potassium. East Afr. Agr. and Forest. J. 36(2):211-239. 
WERNER, J.C.; J.L. QUAGLIATO e D. MARTINELLI. 1967. Ensaio de fertilização de colonião com solo da Noroeste. Bol. Ind. Animal, São Paulo, 24:159-161.

WILSON, J.R. E D.J. MINSON. 1980. Prospects for improving the digestibility and intake of tropical grasses. Trop. Grassland, Brisbane, 14(2):253-257.

WILSON, L.L.; D.D. FISCHER, e T.S. KATSIGIANIS. 1981. Mineral composition of tropical forages and metabolic blood profiles of grazing cattle and sheep on calcium dominatied caribbean soils. Trop. Agric., Trinidad, 58(1):53-62.

ZAGO, C.P. E J.A. GOMIDE, 1982. Valor nutritivo e produtividade do capim colonião submetido a diferentes intervalos de corte com e sem adubação de reposição. Re. Soc. Bras. Zoot., Viçosa, 11(3):5z2-528. 
7. APENDICE

$x$ 
Tabela 1 - Produção de matéria seca a $105^{\circ} \mathrm{C}$ da parte aérea do Colonião (g/vaso) em função dos nĩveis de $N$ e $S$.

\begin{tabular}{crrrr}
\hline Tratamento & \multicolumn{1}{c}{$1^{\mathrm{a}} \mathrm{R}$} & \multicolumn{1}{c}{$2^{\mathrm{a}} \mathrm{R}$} & \multicolumn{1}{c}{$3^{\mathrm{a}} \mathrm{R}$} & \multicolumn{1}{c}{$4^{\mathrm{a}} \mathrm{R}$} \\
\hline $\mathrm{S}_{0} \mathrm{~N}_{0}$ & 6,40 & 7,74 & 5,40 & 6,43 \\
$\mathrm{~S}_{0} \mathrm{~N}_{1}$ & 14,33 & 12,10 & 12,98 & 11,45 \\
$\mathrm{~S}_{0} \mathrm{~N}_{2}$ & 16,21 & 17,64 & 18,73 & 16,01 \\
$\mathrm{~S}_{1} \mathrm{~N}_{0}$ & 5,61 & 6,70 & 5,68 & 8,52 \\
$\mathrm{~S}_{1} \mathrm{~N}_{1}$ & 18,02 & 22,34 & 21,45 & 20,11 \\
$\mathrm{~S}_{1} \mathrm{~N}_{2}$ & 24,00 & 25,92 & 27,70 & 30,38 \\
$\mathrm{~S}_{2} \mathrm{~N}_{0}$ & 7,80 & 6,32 & 4,63 & 6,54 \\
$\mathrm{~S}_{2} \mathrm{~N}_{1}$ & 24,13 & 23,23 & 21,44 & 19,66 \\
$\mathrm{~S}_{2} \mathrm{~N}_{2}$ & 35,09 & 33,91 & 30,38 & 29,49 \\
$\mathrm{~S}_{3} \mathrm{~N}_{0}$ & 8,40 & 6,44 & 6,32 & 8,32 \\
$\mathrm{~S}_{3} \mathrm{~N}_{1}$ & 27,70 & 24,13 & 24,15 & 21,44 \\
$\mathrm{~S}_{3} \mathrm{~N}_{2}$ & 35,49 & 33,06 & 28,99 & 32,08 \\
$\mathrm{~S}_{4} \mathrm{~N}_{0}$ & 6,56 & 6,13 & 8,78 & 5,27 \\
$\mathrm{~S}_{4} \mathrm{~N}_{1}$ & 20,56 & 21,00 & 24,13 & 21,45 \\
$\mathrm{~S}_{4} \mathrm{~N}_{2}$ & 32,17 & 27,70 & 33,96 & 35,00 \\
& & & & \\
& & & &
\end{tabular}


Tabela 2 - Produção de matéria seca a $105^{\circ} \mathrm{C}$ das raízes do Colonião ( $g / v a s o)$ em função dos níveis de $N$ e $S$.

\begin{tabular}{|c|c|c|c|c|}
\hline Tratamento & I. $\mathrm{R}$ & $2^{\mathrm{a}} \cdot \mathrm{R}$ & $3^{a} \cdot R$ & $4^{\mathrm{a}} \cdot \mathrm{R}$ \\
\hline $\mathrm{S}_{0} \mathrm{~N}_{0}$ & 4,60 & 4,60 & 3,22 & 3,68 \\
\hline $\mathrm{S}_{0} \mathrm{~N}_{1}$ & 9,51 & 9,72 & 12,42 & 12,88 \\
\hline $\mathrm{S}_{0} \mathrm{~N}_{2}$ & 9,66 & 13,80 & 13,80 & 12,42 \\
\hline$S_{1} N_{0}$ & 3,68 & 3,68 & 3,68 & 3,68 \\
\hline$S_{l} N_{l}$ & 11,96 & 11,96 & 12,72 & 14,26 \\
\hline $\mathrm{S}_{1} \mathrm{~N}_{2}$ & 13,80 & 16,56 & 13,80 & 17,02 \\
\hline $\mathrm{S}_{2} \mathrm{~N}_{0}$ & 4,60 & 4,60 & 3,68 & 3,22 \\
\hline $\mathrm{S}_{2} \mathrm{~N}_{1}$ & 11,04 & 12,88 & 12,88 & 11,50 \\
\hline $\mathrm{S}_{2} \mathrm{~N}_{2}$ & 15,64 & 13,80 & 16,56 & 16,56 \\
\hline $\mathrm{S}_{3} \mathrm{~N}_{0}$ & 3,68 & 3,68 & 3,68 & 3,68 \\
\hline $\mathrm{S}_{3} \mathrm{~N}_{1}$ & 15,18 & 12,27 & 11,04 & 10,58 \\
\hline $\mathrm{S}_{3} \mathrm{~N}_{2}$ & 16,10 & 14,72 & 19,78 & 16,85 \\
\hline $\mathrm{S}_{4} \mathrm{~N}_{0}$ & 4,14 & 3,68 & 4,60 & 4,60 \\
\hline $\mathrm{S}_{4} \mathrm{~N}_{1}$ & 13,34 & 14,72 & 14,72 & 14,26 \\
\hline $\mathrm{S}_{4} \mathrm{~N}_{2}$ & 17,63 & 17,48 & 16,10 & 19,32 \\
\hline
\end{tabular}


Tabela 3 - Concentração de Nitrogênio em $\&$ na matéria seca $\left(105^{\circ} \mathrm{C}\right)$ da parte aērea do colonião em função dos niveis de $\mathrm{N}$ e $\mathrm{S}$.

\begin{tabular}{|c|c|c|c|c|}
\hline Tratamento & 1. $\mathrm{R}$ & $2^{\mathrm{a}} \mathrm{R}$ & 3. $\mathrm{R}$ & $4^{\mathrm{a}} \mathrm{R}$ \\
\hline $\mathrm{S}_{0} \mathrm{~N}_{0}$ & 0,99 & 1,05 & 1,21 & 0,73 \\
\hline $\mathrm{S}_{0} \mathrm{~N}_{1}$ & 1,36 & 1,29 & 1,34 & 1,09 \\
\hline $\mathrm{S}_{0} \mathrm{~N}_{2}$ & 1,45 & 1,39 & 1,70 & 1,64 \\
\hline$S_{1} N_{0}$ & 0,78 & 0,98 & 0,69 & 1,03 \\
\hline $\mathrm{S}_{1} \mathrm{~N}_{1}$ & 0,91 & 1,06 & 1,48 & 1,54 \\
\hline$S_{1} N_{2}$ & 1,63 & 0,56 & 1,83 & 1,73 \\
\hline $\mathrm{S}_{2} \mathrm{~N}_{0}$ & 0,78 & 1,65 & 0,73 & 1,01 \\
\hline $\mathrm{S}_{2} \mathrm{~N}_{1}$ & 1,13 & 1,29 & 1,38 & 1,41 \\
\hline $\mathrm{S}_{2} \mathrm{~N}_{2}$ & 1,84 & 1,70 & 1,74 & 1,53 \\
\hline $\mathrm{S}_{3} \mathrm{~N}_{0}$ & 0,79 & 0,84 & 0,99 & 1,00 \\
\hline $\mathrm{S}_{3} \mathrm{~N}_{1}$ & 1,54 & 1,08 & 1,00 & 1,29 \\
\hline $\mathrm{S}_{3} \mathrm{~N}_{2}$ & 1,63 & 0,84 & 1,75 & 1,93 \\
\hline $\mathrm{S}_{4} \mathrm{~N}_{0}$ & 0,57 & 0,98 & 1,03 & 0,61 \\
\hline $\mathrm{S}_{4} \mathrm{~N}_{1}$ & 1,01 & 1,25 & 0,95 & 0,99 \\
\hline $\mathrm{S}_{4} \mathrm{~N}_{2}$ & 1,34 & 1,28 & 1,30 & 1,79 \\
\hline
\end{tabular}


Tabela 4 - Concentração de Fósforo em \& na matēria seca (105. C) da parte aérea do Colonião em função dos níveis de $\mathrm{N}$ e $\mathrm{S}$.

\begin{tabular}{ccccc}
\hline Tratamento & $I^{\mathrm{a}} \mathrm{R}$ & $2^{\mathrm{a}} \mathrm{R}$ & $3^{\mathrm{a}} \mathrm{R}$ & $4^{\mathrm{a}} \mathrm{R}$ \\
\hline $\mathrm{S}_{0} \mathrm{~N}_{0}$ & 0,25 & 0,22 & 0,29 & 0,26 \\
$\mathrm{~S}_{0} \mathrm{~N}_{1}$ & 0,18 & 0,16 & 0,18 & 0,17 \\
$\mathrm{~S}_{0} \mathrm{~N}_{2}$ & 0,13 & 0,15 & 0,14 & 0,16 \\
$\mathrm{~S}_{1} \mathrm{~N}_{0}$ & 0,21 & 0,22 & 0,27 & 0,25 \\
$\mathrm{~S}_{1} \mathrm{~N}_{1}$ & 0,17 & 9,18 & 0,18 & 0,15 \\
$\mathrm{~S}_{1} \mathrm{~N}_{2}$ & 0,20 & 0,15 & 0,14 & 0,15 \\
$\mathrm{~S}_{2} \mathrm{~N}_{0}$ & 0,25 & 0,28 & 0,27 & 0,18 \\
$\mathrm{~S}_{2} \mathrm{~N}_{1}$ & 0,13 & 0,20 & 0,18 & 0,22 \\
$\mathrm{~S}_{2} \mathrm{~N}_{2}$ & 0,17 & 0,23 & 0,23 & 0,19 \\
$\mathrm{~S}_{3} \mathrm{~N}_{0}$ & 0,16 & 0,26 & 0,24 & 0,19 \\
$\mathrm{~S}_{3} \mathrm{~N}_{1}$ & 0,20 & 0,25 & 0,21 & 0,22 \\
$\mathrm{~S}_{3} \mathrm{~N}_{2}$ & 0,19 & 0,21 & 0,16 & 0,16 \\
$\mathrm{~S}_{4} \mathrm{~N}_{0}$ & 0,27 & 0,27 & 0,24 & 0,24 \\
$\mathrm{~S}_{4} \mathrm{~N}_{1}$ & 0,20 & 0,25 & 0,19 & 0,19 \\
$\mathrm{~S}_{4} \mathrm{~N}_{2}$ & 0,20 & 0,23 & 0,24 & 0,21 \\
& & & & \\
\hline
\end{tabular}


Tabela 5 - Concentração de Enxofre em $\&$ na matéria seca $\left(105^{\circ} \mathrm{C}\right)$ da parte aérea do Colonião em função dos níveis de $\mathrm{N}$ e $\mathrm{S}$.

\begin{tabular}{ccccc}
\hline Tratamento & $I^{a} \mathrm{R}$ & $2^{\mathrm{a}} \mathrm{R}$ & $3^{\mathrm{a}} \mathrm{R}$ & $4^{\mathrm{a}} \mathrm{R}$ \\
\hline $\mathrm{S}_{0} \mathrm{~N}_{0}$ & 0,08 & 0,06 & 0,06 & 0,06 \\
$\mathrm{~S}_{0} \mathrm{~N}_{1}$ & 0,08 & 0,09 & 0,08 & 0,08 \\
$\mathrm{~S}_{0} \mathrm{~N}_{2}$ & 0,08 & 0,08 & 0,08 & 0,11 \\
$\mathrm{~S}_{1} \mathrm{~N}_{0}$ & 0,07 & 0,07 & 0,07 & 0,08 \\
$\mathrm{~S}_{1} \mathrm{~N}_{1}$ & 1,10 & 0,09 & 0,12 & 0,10 \\
$\mathrm{~S}_{1} \mathrm{~N}_{2}$ & 0,09 & 0,12 & 0,12 & 0,09 \\
$\mathrm{~S}_{2} \mathrm{~N}_{0}$ & 0,06 & 0,07 & 0,09 & 0,06 \\
$\mathrm{~S}_{2} \mathrm{~N}_{1}$ & 0,09 & 0,10 & 0,08 & 0,13 \\
$\mathrm{~S}_{2} \mathrm{~N}_{2}$ & 0,20 & 0,17 & 0,19 & 0,13 \\
$\mathrm{~S}_{3} \mathrm{~N}_{0}$ & 0,10 & 0,08 & 0,07 & 0,07 \\
$\mathrm{~S}_{3} \mathrm{~N}_{1}$ & 0,13 & 0,12 & 0,12 & 0,13 \\
$\mathrm{~S}_{3} \mathrm{~N}_{2}$ & 0,13 & 0,18 & 0,18 & 0,16 \\
$\mathrm{~S}_{4} \mathrm{~N}_{0}$ & 0,11 & 0,08 & 0,08 & 0,09 \\
$\mathrm{~S}_{4} \mathrm{~N}_{1}$ & 0,08 & 0,09 & 0,13 & 0,11 \\
$\mathrm{~S}_{4} \mathrm{~N}_{2}$ & 0,08 & 0,10 & 0,09 & 0,13 \\
\hline
\end{tabular}


Tabela 6 - Concentração de Cálcio em \& na matéria seca $\left(105^{\circ} \mathrm{C}\right)$ da parte áérea do colonião em função dos niveis de $\mathrm{N}$ e $\mathrm{S}$.

\begin{tabular}{ccccc}
\hline Tratamento & $I^{a} \mathrm{R}$ & $2^{\mathrm{a}} \mathrm{R}$ & $3^{\mathrm{a}} \mathrm{R}$ & $4^{\mathrm{a}} \mathrm{R}$ \\
\hline $\mathrm{S}_{0} \mathrm{~N}_{0}$ & 0,58 & 0,63 & 0,57 & 0,55 \\
$\mathrm{~S}_{0} \mathrm{~N}_{1}$ & 0,63 & 0,58 & 0,62 & 0,57 \\
$\mathrm{~S}_{0} \mathrm{~N}_{2}$ & 0,60 & 0,58 & 0,56 & 0,52 \\
$\mathrm{~S}_{1} \mathrm{~N}_{0}$ & 0,58 & 0,64 & 0,62 & 0,62 \\
$\mathrm{~S}_{1} \mathrm{~N}_{1}$ & 0,60 & 0,59 & 0,63 & 0,61 \\
$\mathrm{~S}_{1} \mathrm{~N}_{2}$ & 0,73 & 0,69 & 0,69 & 0,62 \\
$\mathrm{~S}_{2} \mathrm{~N}_{0}$ & 0,66 & 0,67 & 0,68 & 0,63 \\
$\mathrm{~S}_{2} \mathrm{~N}_{1}$ & 0,74 & 0,61 & 0,65 & 0,74 \\
$\mathrm{~S}_{2} \mathrm{~N}_{2}$ & 0,65 & 0,67 & 0,90 & 0,64 \\
$\mathrm{~S}_{3} \mathrm{~N}_{0}$ & 0,63 & 0,69 & 0,79 & 0,63 \\
$\mathrm{~S}_{3} \mathrm{~N}_{1}$ & 0,67 & 0,70 & 0,67 & 1,01 \\
$\mathrm{~S}_{3} \mathrm{~N}_{2}$ & 0,78 & 0,84 & 0,85 & 0,77 \\
$\mathrm{~S}_{4} \mathrm{~N}_{0}$ & 0,27 & 0,27 & 0,24 & 0,34 \\
$\mathrm{~S}_{4} \mathrm{~N}_{1}$ & 0,20 & 0,25 & 0,19 & 0,19 \\
$\mathrm{~S}_{4} \mathrm{~N}_{2}$ & 0,20 & 0,23 & 0,24 & 0,21 \\
\hline
\end{tabular}


Tabela 7 - Nitrogēnio absorvido (mg/vaso) pela parte aërea das plantas de Colonião em função dos níveis de $\mathrm{N}$ e $\mathbf{S}$.

\begin{tabular}{|c|c|c|c|c|}
\hline Tratamento & $I^{\mathrm{a}} \mathrm{R}$ & $2^{\mathrm{a}} \mathrm{R}$ & $3^{\mathrm{a}} \mathrm{R}$ & $4^{\mathrm{a}} \mathrm{R}$ \\
\hline $\mathrm{S}_{0} \mathrm{~N}_{0}$ & 63 & 79 & 65 & 47 \\
\hline $\mathrm{S}_{0} \mathrm{~N}_{1}$ & 195 & 156 & 174 & 125 \\
\hline $\mathrm{S}_{0} \mathrm{~N}_{2}$ & 235 & 245 & 318 & 263 \\
\hline $\mathrm{S}_{1} \mathrm{~N}_{0}$ & 44 & 66 & 39 & 88 \\
\hline$S_{1} N_{1}$ & 164 & 237 & 318 & 310 \\
\hline$S_{1} N_{2}$ & 391 & 404 & 507 & 526 \\
\hline $\mathrm{S}_{2} \mathrm{~N}_{0}$ & 61 & 41 & 34 & 66 \\
\hline $\mathrm{S}_{2} \mathrm{~N}_{1}$ & 273 & 300 & 296 & 277 \\
\hline $\mathrm{S}_{2} \mathrm{~N}_{2}$ & 646 & 577 & 529 & 451 \\
\hline $\mathrm{S}_{3} \mathrm{~N}_{0}$ & 66 & 54 & 63 & 83 \\
\hline $\mathrm{S}_{3} \mathrm{~N}_{1}$ & 427 & 261 & 242 & 277 \\
\hline $\mathrm{S}_{3} \mathrm{~N}_{2}$ & 579 & 608 & 507 & 619 \\
\hline $\mathrm{S}_{4} \mathrm{~N}_{0}$ & 37 & 60 & 91 & 32 \\
\hline $\mathrm{S}_{4} \mathrm{~N}_{1}$ & 208 & 263 & 229 & 212 \\
\hline $\mathrm{S}_{4} \mathrm{~N}_{2}$ & 431 & 355 & 442 & 627 \\
\hline
\end{tabular}


Tabela 8 - Fósforo absorvido (mg/vaso) pela parte aérea das plantas de colonião em função dos niveis de $N$ e $S$.

\begin{tabular}{|c|c|c|c|c|}
\hline Tratamento & l. $\mathrm{R}$ & $2 \cdot \mathrm{R}$ & 3. $\mathrm{R}$ & $4 . \mathrm{R}$ \\
\hline $\mathrm{S}_{0} \mathrm{~N}_{0}$ & 16 & 17 & 16 & 17 \\
\hline $\mathrm{S}_{0} \mathrm{~N}_{1}$ & 26 & 19 & 23 & 20 \\
\hline $\mathrm{S}_{0} \mathrm{~N}_{2}$ & 21 & 27 & 26 & 26 \\
\hline $\mathrm{S}_{1} \mathrm{~N}_{0}$ & 12 & 15 & 15 & 21 \\
\hline $\mathrm{S}_{1} \mathrm{~N}_{1}$ & 31 & 40 & 39 & 30 \\
\hline $\mathrm{S}_{1} \mathrm{~N}_{2}$ & 48 & 39 & 39 & 46 \\
\hline $\mathrm{S}_{2} \mathrm{~N}_{0}$ & 20 & 18 & 13 & 12 \\
\hline $\mathrm{S}_{2} \mathrm{~N}_{1}$ & 31 & 47 & 39 & 43 \\
\hline $\mathrm{S}_{2} \mathrm{~N}_{2}$ & 60 & 7.8 & 70 & 56 \\
\hline $\mathrm{S}_{3} \mathrm{~N}_{0}$ & 13 & 17 & 15 & 16 \\
\hline $\mathrm{S}_{3} \mathrm{~N}_{1}$ & 55 & 60 & 51 & 47 \\
\hline $\mathrm{S}_{3} \mathrm{~N}_{2}$ & 67 & 69 & 46 & 51 \\
\hline $\mathrm{S}_{4} \mathrm{~N}_{0}$ & 18 & 17 & 21 & 18 \\
\hline $\mathrm{S}_{4} \mathrm{~N}_{1}$ & 41 & 53 & 46 & 41 \\
\hline $\mathrm{S}_{4} \mathrm{~N}_{2}$ & 64 & 64 & 82 & 44 \\
\hline
\end{tabular}


Tabela 9 - Enxofre absorvido (mg/vaso) pela parte aérea das plantas de Colonião em função dos níveis de $\mathrm{N}$ e $\mathrm{S}$.

\begin{tabular}{crrrr}
\hline Tratamento & $\mathrm{l}^{\mathrm{a}} \mathrm{R}$ & $2^{\mathrm{a}} \mathrm{R}$ & $3^{\mathrm{a}} \mathrm{R}$ & $4^{\mathrm{a}} \mathrm{R}$ \\
\hline $\mathrm{S}_{0} \mathrm{~N}_{0}$ & 5 & 5 & 3 & 4 \\
$\mathrm{~S}_{0} \mathrm{~N}_{1}$ & 12 & 11 & 10 & 9 \\
$\mathrm{~S}_{0} \mathrm{~N}_{2}$ & 13 & 14 & 15 & 18 \\
$\mathrm{~S}_{1} \mathrm{~N}_{0}$ & 4 & 5 & 4 & 7 \\
$\mathrm{~S}_{1} \mathrm{~N}_{1}$ & 18 & 20 & 26 & 20 \\
$\mathrm{~S}_{1} \mathrm{~N}_{2}$ & 22 & 31 & 33 & 27 \\
$\mathrm{~S}_{2} \mathrm{~N}_{0}$ & 5 & 5 & -4 & 4 \\
$\mathrm{~S}_{2} \mathrm{~N}_{1}$ & 22 & 23 & 17 & 26 \\
$\mathrm{~S}_{2} \mathrm{~N}_{2}$ & 70 & 58 & 58 & 38 \\
$\mathrm{~S}_{3} \mathrm{~N}_{0}$ & 8 & 5 & 5 & 6 \\
$\mathrm{~S}_{3} \mathrm{~N}_{1}$ & 36 & 29 & 29 & 28 \\
$\mathrm{~S}_{3} \mathrm{~N}_{2}$ & 46 & 60 & 52 & 51 \\
$\mathrm{~S}_{4} \mathrm{~N}_{0}$ & 7 & 5 & 7 & 51 \\
$\mathrm{~S}_{4} \mathrm{~N}_{1}$ & 17 & 28 & 31 & 24 \\
$\mathrm{~S}_{4} \mathrm{~N}_{2}$ & 30 & & & 46 \\
\hline
\end{tabular}


Tabela 10 - Cálcio absorvido (mg/vaso) pela parte aérea das plantas de colonião em função dos níveis de $N$ e $S$.

\begin{tabular}{|c|c|c|c|c|c|}
\hline Tratamento & $1^{\mathrm{a}} \mathrm{R}$ & $2^{\mathrm{a}} \mathrm{R}$ & & $3 \cdot \mathrm{R}$ & $4 . \mathrm{R}$ \\
\hline $\mathrm{S}_{0} \mathrm{~N}_{0}$ & 37 & 47 & & 31 & 35 \\
\hline $\mathrm{S}_{0} \mathrm{~N}_{1}$ & 0 & 70 & & 80 & 65 \\
\hline $\mathrm{S}_{0} \mathrm{~N}_{2}$ & 97 & 102 & & 105 & 83 \\
\hline $\mathrm{S}_{1} \mathrm{~N}_{0}$ & 32 & 43 & & 35 & 53 \\
\hline$S_{1} N_{1}$ & 108 & 132 & & 135 & 123 \\
\hline $\mathrm{S}_{1} \mathrm{~N}_{2}$ & 175 & 179 & & 191 & 188 \\
\hline $\mathrm{S}_{2} \mathrm{~N}_{0}$ & 51 & 42 & & 31 & 41 \\
\hline $\mathrm{S}_{2} \mathrm{~N}_{1}$ & 179 & 142 & & 139 & 145 \\
\hline $\mathrm{S}_{2} \mathrm{~N}_{2}$ & 228 & 227 & & 273 & 189 \\
\hline $\mathrm{S}_{3} \mathrm{~N}_{0}$ & 53 & 44 & & 50 & 52 \\
\hline $\mathrm{S}_{3} \mathrm{~N}_{1}$ & 186 & 169 & $:$ & 162 & 217 \\
\hline $\mathrm{S}_{3} \mathrm{~N}_{2}$ & 277 & 278 & & 246 & 247 \\
\hline $\mathrm{S}_{4} \mathrm{~N}_{0}$ & 52 & 48 & & 68 & 47 \\
\hline $\mathrm{S}_{4} \mathrm{~N}_{1}$ & 158 & 153 & & 188 & 167 \\
\hline $\mathrm{S}_{4} \mathrm{~N}_{2}$ & 254 & 249 & & 265 & 304 \\
\hline
\end{tabular}


Tabela 11 - Relação N/S da parte aérea das plantas de colonião em função dos níveis de $\mathrm{N}$ e $\mathrm{S}$.

\begin{tabular}{|c|c|c|c|c|}
\hline Tratamento & $1 \stackrel{\mathrm{a}}{\mathrm{R}}$ & $2^{\mathrm{a}} \mathrm{R}$ & 3. $\mathrm{R}$ & $4 . \mathrm{R}$ \\
\hline $\mathrm{S}_{0} \mathrm{~N}_{0}$ & 12,37 & 17,50 & 20,17 & 12,17 \\
\hline $\mathrm{S}_{0} \mathrm{~N}_{1}$ & 17,00 & 14,33 & 16,75 & 13,62 \\
\hline $\mathrm{S}_{0} \mathrm{~N}_{2}$ & 18,12 & 17,37 & 21,25 & 14,91 \\
\hline $\mathrm{S}_{1} \mathrm{~N}_{0}$ & 11,14 & 14,00 & 9,86 & 12,87 \\
\hline$S_{1} N_{l}$ & 9,10 & 11,78 & 12,33 & 15,40 \\
\hline $\mathrm{S}_{1} \mathrm{~N}_{2}$ & 18,11 & 13,00 & 15,25 & 19,22 \\
\hline $\mathrm{S}_{2} \mathrm{~N}_{0}$ & 13,00 & 9,29 & 8,11 & 16,83 \\
\hline $\mathrm{S}_{2} \mathrm{~N}_{1}$ & 12,56 & 12,90 & 17,25 & 10,85 \\
\hline $\mathrm{S}_{2} \mathrm{~N}_{2}$ & 9,20 & 10,00 & 9,16 & 11,77 \\
\hline $\mathrm{S}_{3} \mathrm{~N}_{0}$ & 7,90 & 10,50 & 14,14 & 14,29 \\
\hline $\mathrm{S}_{3} \mathrm{~N}_{1}$ & 11,85 & 9,00 & 8,33 & 9,92 \\
\hline $\mathrm{S}_{3} \mathrm{~N}_{2}$ & 12,54 & 10,22 & 9,72 & 12,07 \\
\hline $\mathrm{S}_{4} \mathrm{~N}_{0}$ & 5,19 & 12,25 & 12,88 & 6,78 \\
\hline $\mathrm{S}_{4} \mathrm{~N}_{1}$ & 12,63 & 13,85 & 7,31 & 9,00 \\
\hline $\mathrm{S}_{4} \mathrm{~N}_{2}$ & 14,89 & 12,80 & 14,45 & 13,77 \\
\hline
\end{tabular}


Tabela 12 - Relação P/S da parte aérea das plantas de Colonião em função dos níveis de $N$ e $S$.

\begin{tabular}{ccccc}
\hline Tratamento & $I^{\mathrm{a}} \mathrm{R}$ & $2^{\mathrm{a}} \mathrm{R}$ & $3^{\mathrm{a}} \cdot \mathrm{R}$ & $4^{\mathrm{a}} \mathrm{R}$ \\
\hline $\mathrm{S}_{0} \mathrm{~N}_{0}$ & 3,13 & 3,67 & 4,83 & 4,33 \\
$\mathrm{~S}_{0} \mathrm{~N}_{1}$ & 2,25 & 1,78 & 2,25 & 2,13 \\
$\mathrm{~S}_{0} \mathrm{~N}_{2}$ & 1,63 & 1,88 & 1,75 & 1,45 \\
$\mathrm{~S}_{1} \mathrm{~N}_{0}$ & 3,00 & 3,14 & 3,86 & 3,13 \\
$\mathrm{~S}_{1} \mathrm{~N}_{1}$ & 1,70 & 2,00 & 1,50 & 1,50 \\
$\mathrm{~S}_{1} \mathrm{~N}_{2}$ & 2,22 & 1,25 & 1,17 & 1,67 \\
$\mathrm{~S}_{2} \mathrm{~N}_{0}$ & 4,17 & 4,00 & 3,00 & 3,00 \\
$\mathrm{~S}_{2} \mathrm{~N}_{1}$ & 1,44 & 2,00 & 2,25 & 1,69 \\
$\mathrm{~S}_{2} \mathrm{~N}_{2}$ & 0,85 & 1,35 & 1,21 & 1,46 \\
$\mathrm{~S}_{3} \mathrm{~N}_{0}$ & 1,60 & 3,25 & 3,43 & 2,71 \\
$\mathrm{~S}_{3} \mathrm{~N}_{1}$ & 1,54 & 2,08 & 1,75 & 1,69 \\
$\mathrm{~S}_{3} \mathrm{~N}_{2}$ & 1,46 & 1,17 & 0,89 & 1,00 \\
$\mathrm{~S}_{4} \mathrm{~N}_{0}$ & 2,45 & 3,38 & 3,00 & 3,78 \\
$\mathrm{~S}_{4} \mathrm{~N}_{1}$ & 2,50 & 2,78 & 1,46 & 1,73 \\
$\mathrm{~S}_{4} \mathrm{~N}_{2}$ & 2,22 & 2,30 & 2,67 & 1,62 \\
& & & & \\
& & & &
\end{tabular}


Tabela 13 - Rẹação N/P da parte aérea das plantas de coloniạo em função dos nîveis de $\mathrm{N}$ e $\mathrm{S}$.

\begin{tabular}{|c|c|c|c|c|}
\hline Tratamento & $1 \stackrel{\mathrm{a}}{\mathrm{R}}$ & $2 \stackrel{\mathrm{a}}{\mathrm{R}}$ & $3^{\mathrm{a}} \mathrm{R}$ & $4^{\mathrm{a}} \mathrm{R}$ \\
\hline $\mathrm{S}_{0} \mathrm{~N}_{0}$ & 3,96 & 4,77 & 4,17 & 2,81 \\
\hline $\mathrm{S}_{0} \mathrm{~N}_{1}$ & 7,56 & 8,06 & 7,44 & 6,41 \\
\hline $\mathrm{S}_{0} \mathrm{~N}_{2}$ & 11,54 & 9,27 & 12,14 & 10,25 \\
\hline$S_{1} N_{0}$ & 3,71 & 4,45 & 2,56 & 4,12 \\
\hline $\mathrm{S}_{1} \mathrm{~N}_{1}$ & 5,35 & 5,89 & 8,22 & 10,27 \\
\hline $\mathrm{S}_{1} \mathrm{~N}_{2}$ & 8,15 & 10,40 & 13,07 & 11,53 \\
\hline $\mathrm{S}_{2} \mathrm{~N}_{0}$ & 3,12 & 2,32 & 2,70 & 5,51 \\
\hline$S_{2} N_{1}$ & 8,69 & 6,45 & 7,67 & 6,42 \\
\hline $\mathrm{S}_{2} \mathrm{~N}_{2}$ & 10,81 & 7,39 & 7,57 & 8,05 \\
\hline $\mathrm{S}_{3} \mathrm{~N}_{0}$ & 4,94 & 3,23 & 4,12 & 5,26 \\
\hline $\mathrm{S}_{3} \mathrm{~N}_{1}$ & 7,70 & 4,32 & 4,76 & 5,86 \\
\hline $\mathrm{S}_{3} \mathrm{~N}_{2}$ & 8,58 & 8,76 & 10,94 & 12,06 \\
\hline $\mathrm{S}_{4} \mathrm{~N}_{0}$ & 2,11 & 3,63 & 4,29 & 1,79 \\
\hline $\mathrm{S}_{4} \mathrm{~N}_{1}$ & 5,05 & 5,00 & 5,00 & 5,21 \\
\hline $\mathrm{S}_{4} \mathrm{~N}_{2}$ & 6,70 & 5,59 & 5,42 & 8,52 \\
\hline
\end{tabular}


Tabela 14 - Teor de proteína em $\because$ na matéria seca $\left(105^{\circ} \mathrm{C}\right)$ da parte aérea do Colonião em função dos nị̂veis de $N$ e $S$.

\begin{tabular}{|c|c|c|c|c|}
\hline Tratamento & $1 \stackrel{\mathrm{a}}{\mathrm{R}}$ & $2 \mathrm{a} \cdot \mathrm{R}$ & $3 \cdot \mathrm{R}$ & $4^{\mathrm{a}} \cdot \mathrm{R}$ \\
\hline $\mathrm{S}_{0} \mathrm{~N}_{0}$ & 6,19 & 6,56 & 1,56 & 4,56 \\
\hline $\mathrm{S}_{0} \mathrm{~N}_{1}$ & 8,50 & $8-06$ & 8,37 & 6,81 \\
\hline $\mathrm{S}_{0} \mathrm{~N}_{2}$ & 9,06 & 8,68 & 10,62 & 10,25 \\
\hline$S_{1} N_{0}$ & 4,87 & 6,12 & 4,31 & 6,44 \\
\hline$S_{1} N_{1}$ & 5,69 & 6,62 & 9,25 & 9,62 \\
\hline $\mathrm{S}_{1} \mathrm{~N}_{2}$ & 10,19 & 9,75 & 11,44 & 10,81 \\
\hline $\mathrm{S}_{2} \mathrm{~N}_{0}$ & 4,87 & 4,06 & 4,56 & 6,31 \\
\hline $\mathrm{S}_{2} \mathrm{~N}_{1}$ & 7,06 & 8,06 & 8,62 & 8,81 \\
\hline $\mathrm{S}_{2} \mathrm{~N}_{2}$ & 11,50 & 10,62 & 10,87 & 9,56 \\
\hline $\mathrm{S}_{3} \mathrm{~N}_{0}$ & 4,94 & 5,25 & 6,19 & 6,25 \\
\hline $\mathrm{S}_{3} \mathrm{~N}_{1}$ & 9,62 & 6,75 & 6,25 & 8,06 \\
\hline $\mathrm{S}_{3} \mathrm{~N}_{2}$ & 10,19 & 11,50 & 10,94 & 12,06 \\
\hline $\mathrm{S}_{4} \mathrm{~N}_{0}$ & 3,26 & 6,12 & 6,43 & 3,81 \\
\hline $\mathrm{S}_{4} \dot{\mathrm{N}}_{1}$ & 6,31 & 7,81 & 5,94 & 6,19 \\
\hline $\mathrm{S}_{4} \mathrm{~N}_{2}$ & 8,27 & 8,00 & 8,12 & 11,19 \\
\hline
\end{tabular}


Tabela 15 - Digestibilidade "in vitro" de matéria seca $\left(105^{\circ} \mathrm{C}\right)$ da parte aérea do Colonião em função dos niveis de $\mathrm{N}$ e $\mathrm{S}$.

\begin{tabular}{|c|c|c|c|c|}
\hline Tratamento & $1 \stackrel{\mathrm{a}}{\mathrm{R}}$ & $2^{a} \cdot R$ & $3 \cdot \mathrm{R}$ & $4 \cdot \mathrm{R}$ \\
\hline $\mathrm{S}_{0} \mathrm{~N}_{0}$ & 29,88 & 24,01 & 34,47 & 29,83 \\
\hline $\mathrm{S}_{0} \mathrm{~N}_{1}$ & 40,50 & 40,40 & 38,25 & 38,43 \\
\hline $\mathrm{S}_{0} \mathrm{~N}_{2}$ & 40,44 & 41,44 & 39,92 & 43,75 \\
\hline $\mathrm{S}_{1} \mathrm{~N}_{0}$ & 38,97 & 36,04 & 34,15 & 32,42 \\
\hline $\mathrm{S}_{1} \mathrm{~N}_{1}$ & 51,47 & 48,07 & 47,98 & 47,66 \\
\hline $\mathrm{S}_{1} \mathrm{~N}_{2}$ & 47,46 & 44,88 & 41,32 & $.43,78$ \\
\hline $\mathrm{S}_{2} \mathrm{~N}_{0}$ & 41,95 & 31,93 & 38,43 & 36,00 \\
\hline $\mathrm{S}_{2} \mathrm{~N}_{1}$ & 49,25 & 48,76 & 50,21 & 48,78 \\
\hline $\mathrm{S}_{2} \mathrm{~N}_{2}$ & 59,09 & 47,23 & 51,99 & 48,15 \\
\hline $\mathrm{S}_{3} \mathrm{~N}_{0}$ & 41,45 & 35,65 & 39,92 & 42,73 \\
\hline $\mathrm{S}_{3} \mathrm{~N}_{1}$ & 42,64 & 42,61 & 48,38 & 43,71 \\
\hline $\mathrm{S}_{3} \mathrm{~N}_{2}$ & 43,33 & 52,24 & 48,27 & 46,73 \\
\hline $\mathrm{S}_{4} \mathrm{~N}_{0}$ & 38,59 & 36,05 & 36,54 & 32,93 \\
\hline $\mathrm{S}_{4} \mathrm{~N}_{1}$ & 54,62 & 51,45 & 45,77 & 47,68 \\
\hline $\mathrm{S}_{4} \mathrm{~N}_{2}$ & 49,33 & 47,37 & 46,60 & 43,19 \\
\hline
\end{tabular}

